Universidad deValladolid

PROGRAMA DE DOCTORADO EN INVESTIGACIÓN EN CIENCIAS

DE LA SALUD

TESIS DOCTORAL:

\title{
DESARROLLO Y UTILIDAD DE LAS TÉCNICAS DE ELISA Y QUIMIOLUMINISCENCIA PARA EL DIAGNÓSTICO DE LA TULAREMIA HUMANA
}

\author{
Presentada por D. Carlos Durántez Fernández para \\ optar al grado de \\ Doctor/a por la Universidad de Valladolid
}

Dirigida por:

Dr. Antonio Orduña Domingo

Dra. María Simarro Grande

Dra. María José Castro Alija 

"El triunfo supremo de la razón, (...) es poner en duda su propia validez"

Miguel de Unamuno, Del sentimiento trágico de la vida 



\section{Agradecimientos}

Llegados a este momento final de la tesis solo me queda agradecer a todas aquellas personas que han estado conmigo durante estos cuatro años de doctorado.

En primer lugar, a mis directores, en especial al Dr. Antonio Orduña, pues sin su confianza en mí hace 5 años cuando entré por primera vez en el Departamento de Microbiología hoy no estaría aquí. Gracias por convertirme en uno más del departamento sin apenas conocerme y por ayudarme siempre que lo he necesitado como buen maestro y mentor. Toda esa confianza se ha traducido en el profundo afecto por la investigación y la docencia que he adquirido de usted, y espero que se desarrolle durante los próximos años sobre esta sólida base. A la Dra. María Simarro, a quien no tuve el gusto de conocer hasta la mitad de mi tesis, pero que en este poco tiempo ha contribuido enormemente a mi formación con su apoyo y cariño. Gracias a ella he podido ampliar mis conocimientos en materias totalmente ajenas a mi formación y a la vez retomar el contacto con mis raíces en el campo de la Enfermería, también debo agradecerle todo su ánimo y ayuda para que pudiese vivir la experiencia de una estancia en un laboratorio de gran prestigio como es el Xlab de la Universidad de Copenhague. Así como a la Dra. María José Castro.

También quiero destacar a todas esas personas que a nivel personal y profesional han contribuido de una manera muy importante para mí.

Al Dr. Miguel Ángel De la Fuente, Dra. Purificación Gutiérrez y Dra. Clara Prats por trasmitirme sus conocimientos con una sonrisa y hacer que en estos años haya aprendido muchas cosas sobre genética molecular, microbiología y microscopía.

A todos mis compañeros de poyata y campana en el departamento, el hospital y el IBGM. Muchas gracias a Raquel, Roberto, Ana, Dolores, Concepción, Irene, Julia y Dino con quienes he aprendido en los buenos y malos momentos que el trabajo de campo es tremendamente gratificante, 
aunque en ocasiones nos desesperen los resultados. Tampoco me quiero olvidar de Isabel por su inestimable ayuda en el insondable mundo de la administración de la Universidad y de Juanjo por hacer que los cursos de la EsdUVa sean más llevaderos.

A la Universidad de Valladolid, gracias a la cual desde octubre de 2016 he podido disponer de un contrato predoctoral para llevar a cabo esta tesis doctoral.

Finalmente, y por ello no menos importante, quisiera dar las gracias a mi familia por aguantarme pacientemente en los momentos de estrés y por apoyarme plenamente con su comprensión y cariño en esta etapa que se cierra. 
ÍNDICE 



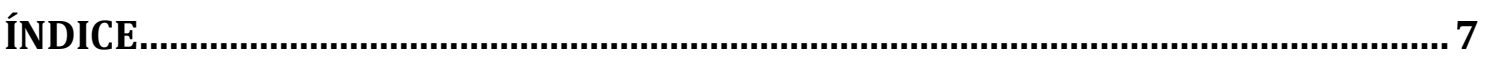

INTRODUCCIÓN...............................................................................................11

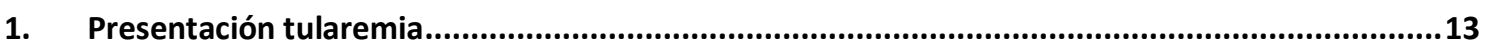

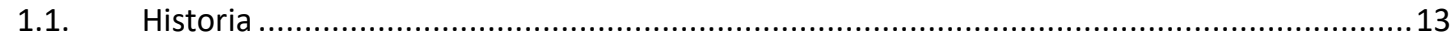

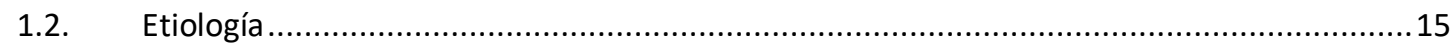

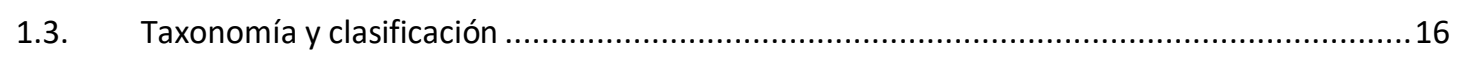

2. Estructura antigénica y factores de virulencia....................................................................19

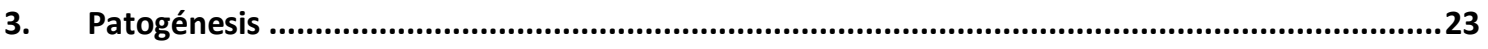

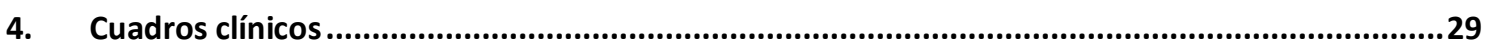

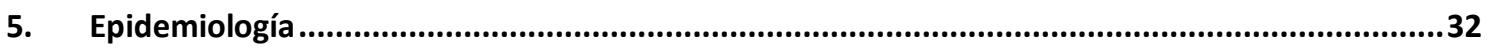

5.1. Reservorios y especies susceptibles de padecer tularemia ........................................32

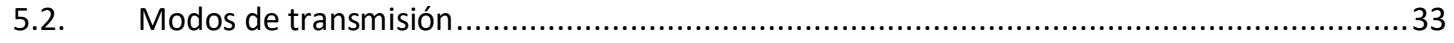

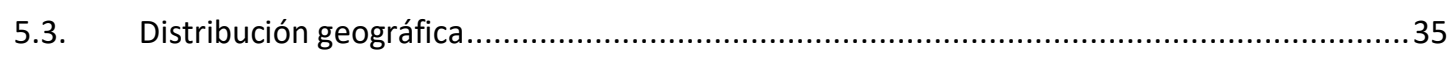

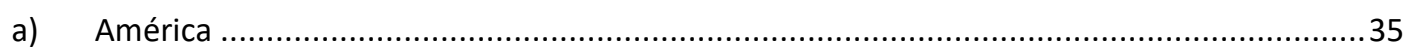

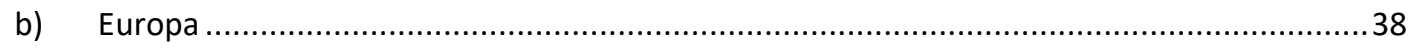

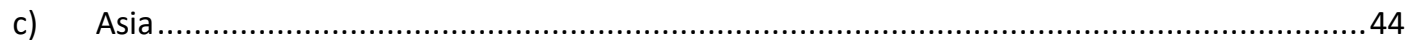

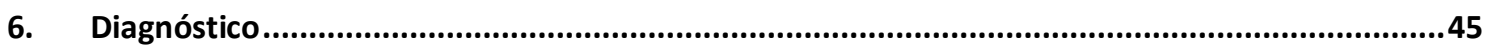

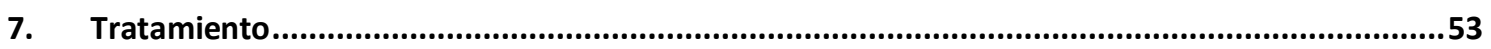

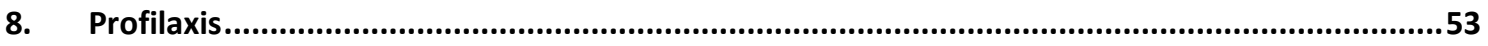

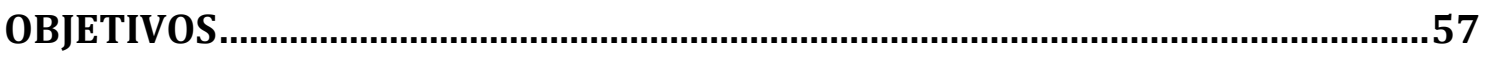

MATERIAL Y MÉTODOS....................................................................................61

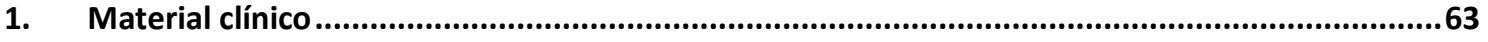

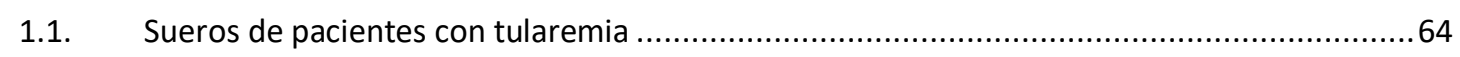

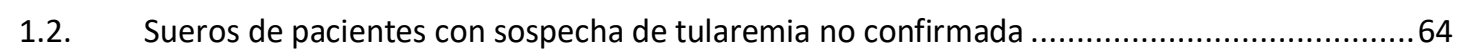

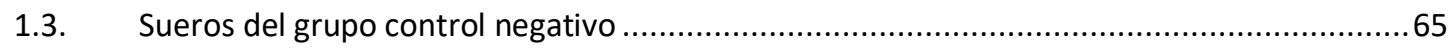

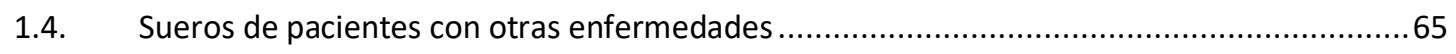

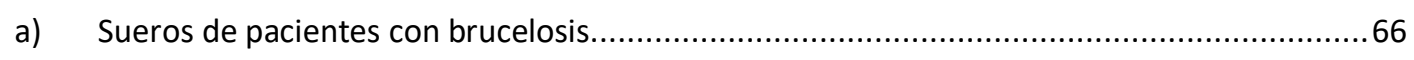

b) Sueros de pacientes con enfermedades autoinmunes...................................................67

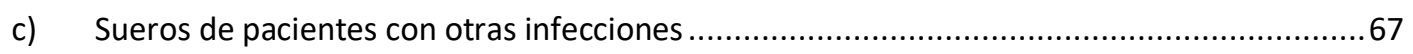




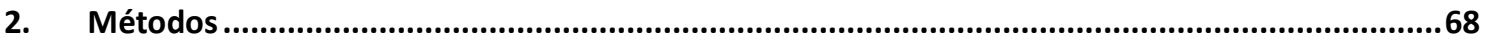

2.1. Obtención de los antígenos microbianos ...........................................................68

a) Preparación de la suspensión madre de Francisella tularensis........................................68

b) Preparación y estandarización del antígeno corpuscular para microaglutinación.................69

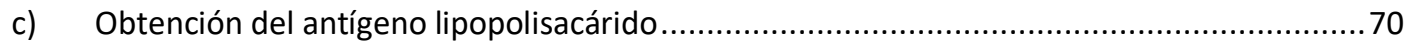

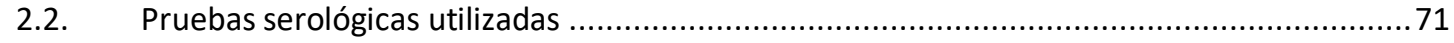

a) Prueba de microaglutinación en placa ............................................................... 71

b) Prueba de ELISA frente a lipopolisacárido de Francisella tularensis (ELISA IgG y ELISA IgM) .72

c) Prueba de quimioluminiscencia frente a lipopolisacárido de F. tularensis (Tularemia Virclia ${ }^{\circ}$

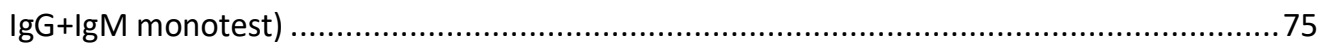

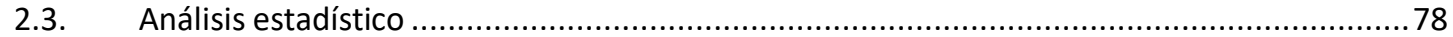

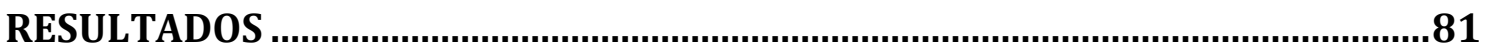

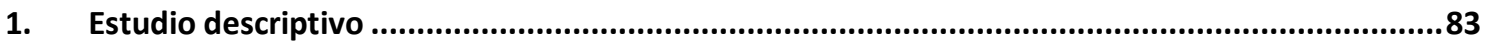

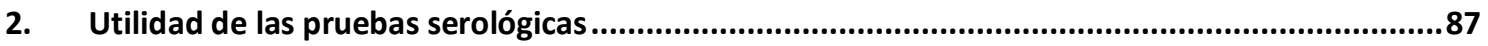

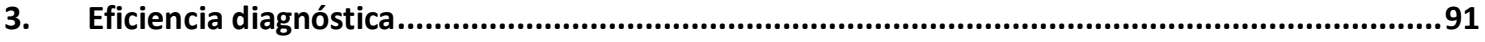

3.1. Eficiencia diagnóstica de la prueba de quimioluminiscencia ......................................91

3.2. Eficiencia diagnóstica de la prueba de microaglutinación en placa ...................................92

3.3. Eficiencia diagnóstica de las pruebas de ELISA IgG-IgM .............................................94

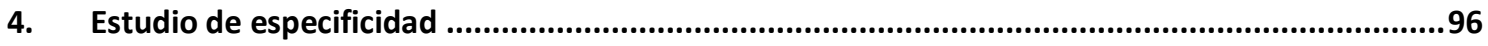

4.1. Pacientes con sospecha de tularemia no confirmada y otras patologías ..........................96

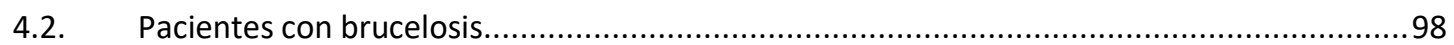

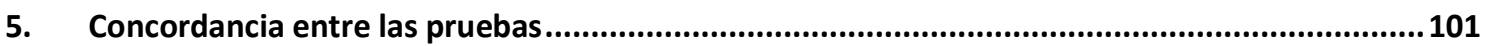

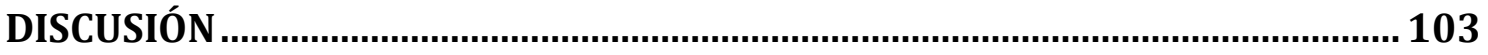

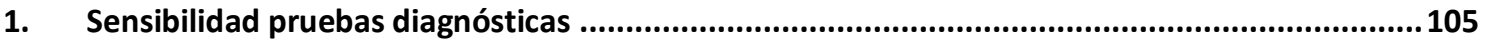

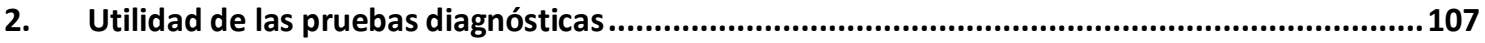

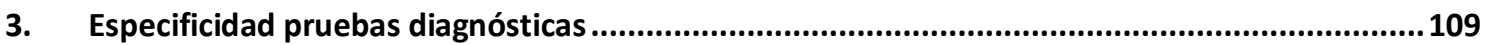

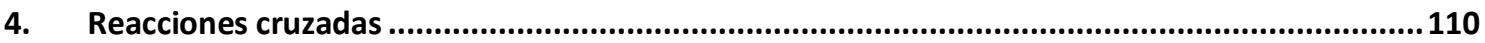

CONCLUSIONES................................................................................................ 113

BIBLIOGRAFÍA .................................................................................................. 117

ANEXOS ....................................................................................................................... 139 
INTRODUCCIÓN 



\section{Presentación tularemia}

\subsection{Historia}

"The bubo is usually about the size of a pea and the gland structure is generally replaced by a firm caseous mass". Con estas palabras describió George McCoy en 1911 por primera vez la tularemia en la publicación " $A$ Plague-like Disease of Rodents", el descubrimiento se hizo sobre un grupo de ardillas de tierra en California (EE.UU.) mientras investigaba las plagas aparecidas tras el terremoto de San Francisco de 1906 1,2.

Un año después (1912) y en compañía de Chapin consiguen aislar el agente etiológico al que deciden nombrar como Bacterium tularense debido a que su descubrimiento se realizó en el condado de Tulare (California, EE.UU.) ${ }^{2,3}$. Aunque en un primer momento no se relacionó con el Bacterium tularense, la tularemia también se estaba transmitiendo en Utah como consecuencia de la picadura de moscas, esta enfermedad era conocida como "fiebre de la mosca del venado" 3 .

Por su parte Werry y Lamb en 1914 publican un artículo en la revista "The Journal of Infectious Diseases" describiendo el primer caso de tularemia humana documentado con Bacterium tularense como agente etiológico, se trataba de un joven trabajador de un restaurante que manipuló carne contaminada, desarrollando la enfermedad en su forma oculoglandular 4,5 .

A pesar de que en un primer momento se consideró a la tularemia como una enfermedad exclusiva de los Estados Unidos, pronto se descartó esta hipótesis al describir Hachiro Ohara una enfermedad similar en Japón en los años $20^{1}$, aunque las primeras referencias en Japón a una enfermedad humana con características similares a la tularemia y asociada a las liebres datan de $1818^{5,6}$. El Dr. Ohara diagnosticó la enfermedad en una familia que había despellejado y consumido una liebre muerta, para confirmar el diagnóstico realizó la autopsia de otra liebre muerta que encontró en la zona y frotó el corazón de la liebre sobre la mano de su esposa, ella desarrolló la 
enfermedad en menos de una semana y el Dr. Ohara aisló las bacterias a partir de sus ganglios linfáticos ${ }^{3,7}$.
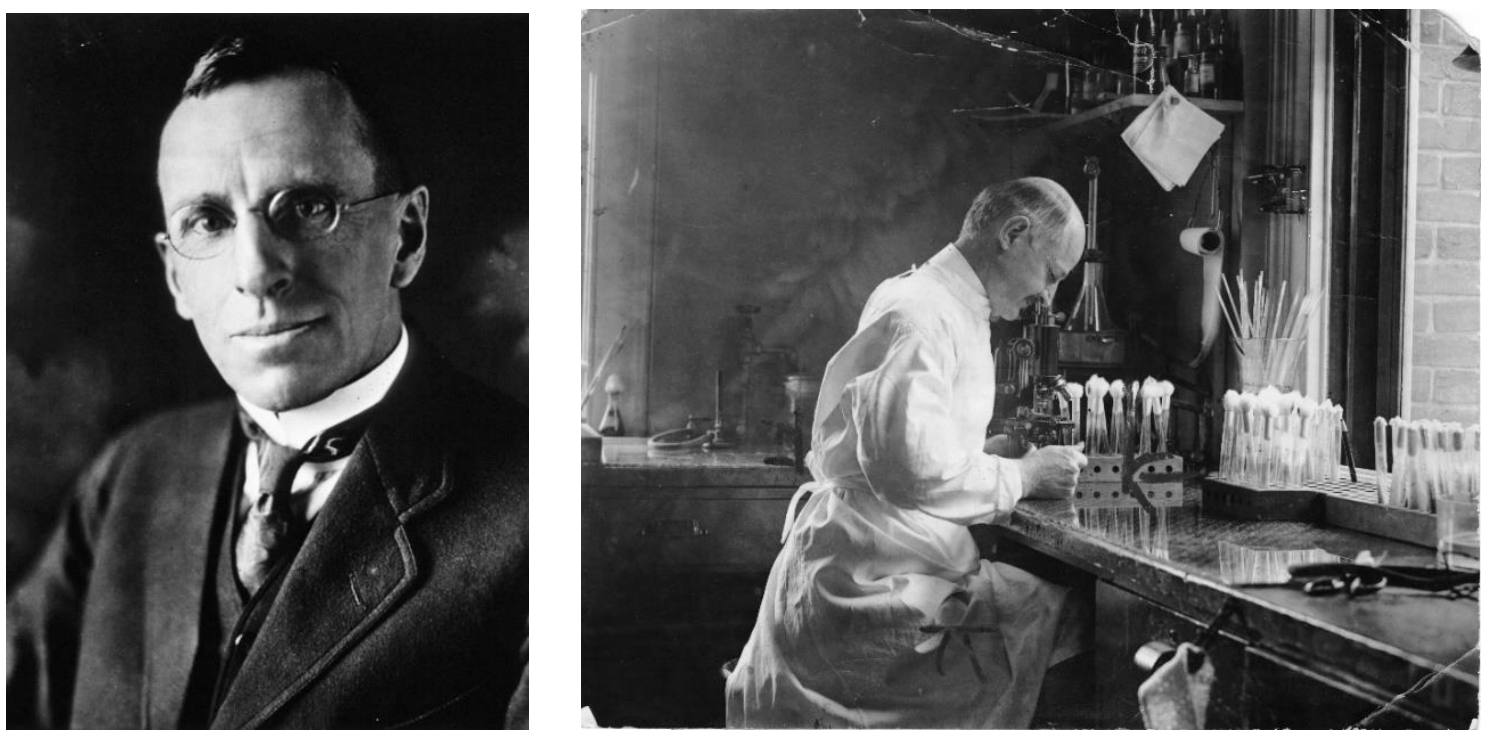

Figura 1 (izda.): Dr. George W. McCoy (Office of NIH History and Stetten Museum)

Figura 2 (dcha.): Dr. Edward Francis (Smithsonian Institution Archives. Image \# SIA2008-1667)

Pero si alguien ha contribuido realmente al conocimiento de la tularemia ese es el Dr. Edward Francis, sus trabajos clínicos y epidemiológicos en 1928 sobre una población de más de 600 casos humanos le permitieron grandes avances, entre los que destacan:

- Junto con Parker y Spencer demostró que la mosca del venado y las garrapatas son vector de transmisión de la enfermedad ${ }^{5,8}$.

- Cambia el nombre de la enfermedad de "fiebre de la mosca del venado" a tularemia, al haber sido asignada la causalidad de la "fiebre de la mosca del venado" al Bacterium tularense ${ }^{4}$.

- Confirma serológicamente 5 de los casos de tularemia diagnosticados en Japón por Ohara, demostrando que la enfermedad que sucede en Estados Unidos y Japón es la misma ${ }^{3-5}$. 
- Aclara los síndromes clínicos asociados con la tularemia y la distribución epidemiológica de la misma en Estados Unidos ${ }^{3,4}$.

- La enfermedad afecta a gran parte del personal de laboratorio encargado de investigar la tularemia, tanto McCoy y Chapin como el propio Francis se infectaron con la bacteria. Esta elevada incidencia de la enfermedad hace que el Dr. Francis proponga el uso de precauciones especiales al usar técnicas de laboratorio que manipulen sustancias clínicas o animales contaminados ${ }^{3,4}$.

- Los trabajos del Dr. Francis también contribuyeron a mejorar los métodos para el cultivo del $B$. tularense, pues identificó a la cisteína como el suplemento presente en la yema de huevo coagulada que ayuda al crecimiento de la bacteria ${ }^{4}$.

Por todas estas razones en 1959 se cambia el nombre de la bacteria de Bacterium tularense a Francisella tularensis en honor al Dr. Edward Francis ${ }^{5}$.

\subsection{Etiología}

La tularemia es una zoonosis causada por bacterias de la especie Francisella tularensis. Estas bacterias son pequeños cocobacilos gram negativos $(0,2-0,7 \times 0,2 \mu \mathrm{m}$ en el caso de las subespecies tularensis, holarctica y mediasiatica o $0,7 \times 1,7 \mu \mathrm{m}$ de la especie philomiragia y de la subespecie novicida), con gran pleomorfismo durante su etapa de crecimiento logarítmico y que presentan una tinción bipolar con métodos de Gram o Giemsa (lo que acentúa su aspecto de cocos) ${ }^{3,9-11}$.

No producen endosporas, son inmóviles, oxidasa negativa y catalasa débilmente positiva ${ }^{9,11,12}$. Son aerobias estrictas y las subespecies Francisella tularensis tularensis, Francisella tularensis holarctica y Francisella tularensis mediasiatica requieren de la presencia de cistina o cisteína para su crecimiento $3,9,11$.

Esta bacteria es muy resistente al medio ambiente y puede sobrevivir durante semanas a bajas temperaturas en agua, barro, paja y heno, así como 
en los cadáveres de animales infectados ${ }^{3,10}$. La bacteria es en cambio sensible a los desinfectantes habituales (hipoclorito) y se inactiva por calor $\left(60^{\circ} \mathrm{C}\right.$ durante una hora). Es, así mismo, sensible a una amplia variedad de antibióticos ${ }^{13}$.

La pared celular posee un nivel inusualmente elevado de ácidos grasos que confieren un perfil único al género y las cepas salvajes tienen una cápsula electrotransparente rica en lípidos ${ }^{3,10}$.

\subsection{Taxonomía y clasificación}

La familia Francisellaceae consta de un único género (Francisella) que tiene tres especies, las cuales se pueden identificar a partir de un análisis de la composición de ácidos grasos, y cuatro subespecies dentro de la especie Francisella tularensis ${ }^{3}$.

Taxonómicamente la especie Francisella tularensis se encuentra incluida dentro de la familia Francisellaceae ${ }^{3,9}$.

- División $\rightarrow$ Proteobacteria

- Clase $\rightarrow$ Gammaproteobacteria

- Orden $\rightarrow$ Thiotrichales

- Familia $\rightarrow$ Francisellaceae

- Género $\rightarrow$ Francisella

- Especie:

1) Philomiragia

2) Hispaniensis

3) Tularensis

- Subespecie:
a) Tularensis
b) Holarctica
c) Novicida
d) Mediasiatica 
Tienen un alto grado de similitud genética, ya que en base a la secuenciación de los genes 16S rRNA llegan a presentar una homología mayor del $98 \%$ entre las subespecies de Francisella tularensis ${ }^{9,14}$. Sin embargo, las diferencias espectrométricas basadas en MALDI-TOF (Matrix-Assisted Laser Desorption/lonization Time-Of-Flight, en español desorción/ionización láser asistida por matriz), permiten la diferenciación y tipificación de las especies y subespecies de Francisella, aunque éstas también presentan diferencias en función de ${ }^{3,10}$ :

- Características de crecimiento.

- Reacciones bioquímicas.

- Propiedades de virulencia.

Los métodos fenotípicos han sido utilizados hasta hace muy pocos años en todos los laboratorios para su identificación, hasta ser sustituidos muy recientemente por los métodos espectrométricos (MALDI-TOF).

A pesar de que toda la familia Francisellaceae puede producir enfermedad en humanos, la tularemia humana es producida principalmente por las subespecies F. tularensis subsp. tularensis y F. tularensis subsp. holarctica 3,15 .

- Francisella philomiragia: anteriormente clasificada como Yersinia philomiraiga, se clasificó posteriormente dentro del género Francisella dado que comparte con este género el perfil de ácidos grasos, así como la gran homología de ADN. No se considera una subespecie de $F$. tularensis por poseer características bioquímicas propias y patrones de hibridación de ADN diferentes ${ }^{11,16}$.

Presenta una baja virulencia para los humanos y se encuentra de modo natural en el agua salada ${ }^{3}$.

- Francisella hispaniensis: aislada en sangre y orina de un paciente séptico en España, se considera una especie diferente dadas sus características fenotípicas y genotípicas ${ }^{3}$. 
- Francisella tularensis:

a) Francisella tularensis subsp. tularensis o tipo A de Jellison: es la variedad más virulenta y se localiza casi exclusivamente en Norteamérica, aunque en los últimos años se han aislado cepas en Europa, concretamente en zonas cercanas a Bratislava (Eslovaquia) y en Austria ${ }^{15,17,18}$.

b) Francisella tularensis subsp. holarctica o tipo B de Jellison: se encuentra sobre todo en Asia, Europa y Norteamérica. De esta subespecie procede la cepa vacunal (LVS). Francisella tularensis subsp. holarctica ha sido la principal causante de los brotes epidémicos habidos en España en 1997-1998 y 2007-2008; es menos virulenta en el ser humano que la subespecie tularensis.

Se han descrito tres biotipos según sus características bioquímicas 15,19:

- Biotipo 1: se caracterizan por ser sensibles a la eritromicina y se localizan en el oeste de Europa.

- Biotipo 2: se caracterizan por ser resistentes a la eritromicina y se localizan en Europa del este.

- Biotipo japonica: se localizan principalmente en Japón, aunque también se han descrito casos en China y Turquía ${ }^{3}$.

c) Francisella tularensis subsp. novicida: bajo grado de virulencia, se trata de la subespecie menos prevalente ${ }^{11}$.

d) Francisella tularensis subsp. mediaasiatica: también suponen una baja virulencia, similar a $F$. tularensis subsp. holarctica. Las cepas de esta variedad se han localizado exclusivamente en regiones de Asia central, concretamente en Kazajistán y Turkmenistán ${ }^{11}$. 


\section{Estructura antigénica y factores de virulencia}

Francisella tularensis presenta un complicado ciclo de vida intracelular, puede infectar una amplia variedad de tipos de células hospedadoras y carece de los factores de virulencia bacteriana clásicos, como las exotoxinas o el sistema de secreción tipo III ${ }^{3,20}$. Otra característica es que las subespecies de Francisella tularensis poseen antígenos comunes por lo que la respuesta serológica es común, lo que imposibilita su identificación serológica ${ }^{3}$.

Dentro de los factores de virulencia de Francisella se encuentran:

- Cápsula: este elemento generalmente protege a las bacterias de la lisis mediada por el complemento, la fagocitosis y el reconocimiento inmunológico 21,22. Esto puede parecer contraproducente para las bacterias intracelulares, pero se ha descubierto que en el caso de Francisella tularensis juega un papel clave en la virulencia de la bacteria puesto que ayuda a evitar los mecanismos de detección intracelular, limitando la inflamación y promoviendo la supervivencia intracelular, si bien será necesario llevar a cabo más estudios para conocer mejor el papel de la cápsula de Francisella en la resistencia al suero ${ }^{3,22}$.

El análisis bioquímico indica que la cápsula está compuesta en torno a un $50 \%$ de lípidos, y hasta un $35 \%$ de aminoácidos y un $21 \%$ de carbohidratos. Pero lo que caracteriza principalmente a la cápsula de Francisella es que muchas de las cepas analizadas expresan un polisacárido que es idéntico al antígeno $O$ del lipopolisacárido, lo que lleva a pensar si la cápsula de Francisella tularensis es real o si la bacteria simplemente expresa el antígeno $O$ libre que se agrega cerca de la superficie ${ }^{22}$.

- Lipopolisacárido (LPS): es el componente mayoritario y más externo de la membrana externa de la mayoría de bacterias gram negativas. EI LPS consta principalmente de tres partes: lípido A, núcleo y antígeno $\mathrm{O}^{3,21,22}$. 
El lípido $A$ es la endotoxina de las bacterias, debido a su función inmunoestimulante es una estrategia de virulencia común para muchas bacterias gram negativas. En el caso de Francisella tularensis, el lípido A presenta una estructura ligeramente modificada, está tetraacilado con cadenas de ácidos grasos de 16 a 18 carbonos de longitud (generalmente en las bacterias gram negativas está hexaacilado con cadenas de ácidos grasos de 12 a 14 carbonos), lo que permite a la bacteria reducir en gran medida la activación de los receptores TLR4 y posibilita una mayor evasión inmunológica ${ }^{21-23}$.

El núcleo es la zona del polisacárido que se encarga de unir la parte del lípido A con el antígeno $O$.

Por su parte, el antígeno $\mathrm{O}$ son las cadenas laterales del polisacárido, constituye el principal antígeno de superficie de las células gram negativas y es altamente inmunógeno en animales vertebrados ${ }^{3}$.

Se ha demostrado que las diferentes especies de Francisella tularensis han desarrollado variaciones fundamentales en la estructura del LPS que además de posibilitar la evasión inmunológica, dan lugar a mejoras en la virulencia de la bacteria provocando una alta infectividad y una enfermedad más grave ${ }^{22}$.

- Sistemas de secreción: permiten el paso de proteínas a través de la membrana y se encuentran codificados por genes de la isla de patogenicidad de Francisella (FPI, del inglés Francisella pathogenicity island). Dicha isla de patogenicidad es una región de $30 \mathrm{~kb}$ del genoma que está presente en dos copias idénticas, cada una de las cuales contiene 19 genes organizados en dos grandes operones. Estos genes son esenciales en la virulencia de la bacteria y en su crecimiento intracelular ${ }^{3,22}$.

- Sistemas de secreción tipo I (T1SS): en Francisella tularensis se compone por TolC y FtlC, y una proteína homóloga SilC de la que se desconoce su papel, todos están localizados en la membrana externa ${ }^{22}$. 
- Sistemas de secreción tipo III y IV (T3SS/T4SS): no se encuentran en Francisella tularensis subsp. tulatensis ni en Francisella tularensis subsp. holarctica, por lo que se cree que no interviene en la virulencia en humanos ${ }^{22}$.

- Sistemas de secreción tipo VI (T6SS): como veremos más adelante se encuentra implicado en la evasión del fagosoma ${ }^{3,22}$.

- Proteínas secretadas: varias proteínas son liberadas por Francisella tularensis (destacando AcpA, KatG y SodB) aunque los mecanismos para su secreción no están muy claros, se cree que tanto TolC del sistema de secreción tipo I como el sistema de secreción tipo VI son los principales responsables. También se eliminan de forma espontánea a través de vesículas de la membrana externa (OMVs, del inglés Outer Membrane Vesicles) ${ }^{22}$.

- Proteínas de membrana: pueden estar localizadas en la membrana externa (OMPs, del inglés Outer Membrane Proteins), en la membrana interna (IMPs, del inglés Inner Membrane Proteins) o en el periplasma.

- Proteínas de la membrana externa (OMPs): debido a su localización superficial pueden desempeñar funciones como factores de virulencia o como objetivos inmunes.

Como hemos visto anteriormente, las proteínas pueden ser secretadas al medio a través de vesículas, analizando el contenido de las OMVs se han descubierto numerosas OMPs, entre las que destacan: FopA, KatG, Pal, Tul4-A, Mip, Dsb ${ }^{22}$.

Además de las OMPs mencionadas anteriormente, también son importantes las proteínas DsbA, Flpp3, DipA, OmpA, FupA y FsIE como factores de virulencia de Francisella tularensis ${ }^{21,22}$.

- Proteínas de la membrana interna (IMPs): a pesar de la naturaleza esencial de estas proteínas para la viabilidad bacteriana, han sido menos estudiadas que las de la membrana externa.

Aquellas que se conoce que actúan como factores de virulencia son: RipA, SecY, LolC, LpxE, LpxF, KdoH1, KdoH2 y Cht1 ${ }^{22}$. 
- Proteínas periplásmicas: se cree que SodC actúa a nivel del periplasma ${ }^{22}$.

- Pili de tipo IV: se encuentran en la superficie de muchos tipos de bacterias y generalmente desempeñan funciones importantes en la adhesión bacteriana, la agregación, la motilidad mediante contracción y la captación de ADN. Su papel en la familia Francisellaceae no está claro puesto que solo se han encontrado en algunas especies desarrolladas en laboratorio ${ }^{3,22}$.

El estudio e identificación de los diferentes antígenos de membrana permitirá confirmar cuales son los antígenos inmunodominantes de Francisella tularensis y su importancia inmunopatogénica y protectora $3,24,25$.

En la siguiente imagen podemos ver un resumen de todos los factores de virulencia de Francisella tularensis.

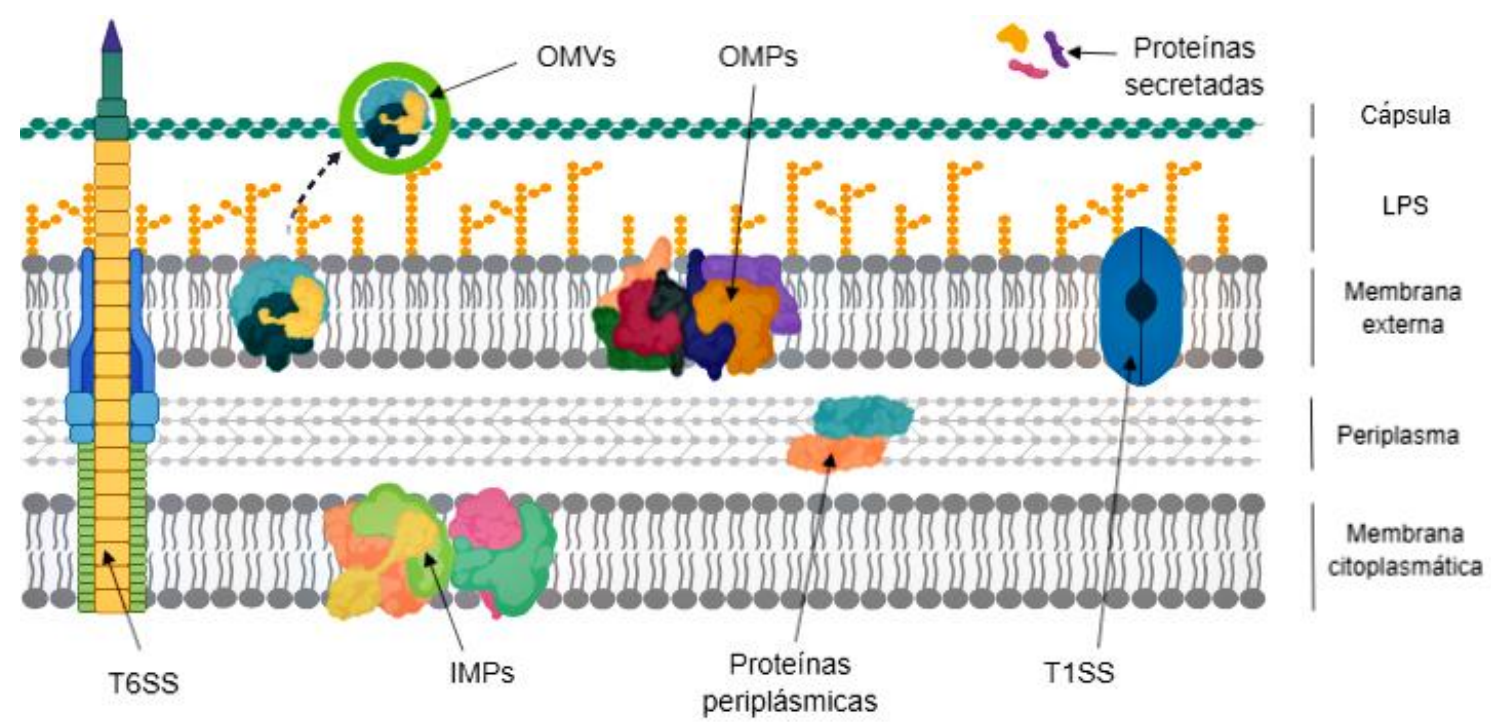

Figura 3: Principales factores de virulencia de Francisella tularensis (Elaboración propia) 


\section{Patogénesis}

Debido a su carácter de bacteria intracelular facultativa, uno de los aspectos clave del ciclo vital de Francisella tularensis es su desarrollo dentro de las células del organismo hospedador. Por ello son diversos los mecanismos que Francisella desarrolla para su supervivencia y replicación en este medio tan hostil.

\section{- Fagocitosis}

El reconocimiento de Francisella en la membrana de las células hospedadoras es un paso fundamental, puesto que va a posibilitar la entrada de las bacterias en el interior de las células ${ }^{26}$. Existen múltiples células en las que Francisella puede sobrevivir y proliferar, destacando: macrófagos, células dendríticas, neutrófilos, hepatocitos, neumocitos tipo II y células endoteliales 27.

Dicho reconocimiento es llevado a cabo por receptores de reconocimiento de patrones (PRRs, del inglés Pattern Recognition Receptor), los cuales reconocen patrones moleculares asociados a patógenos (PAMPs, del inglés Pathogen-Associated Molecular Patterns) y desencadenan la respuesta inflamatoria indicada. Dentro de los PRRs encontramos receptores localizados en la superficie celular como son los receptores de tipo Toll (TLRs, del inglés Toll-like receptor) o en el citosol como los receptores de tipo Nod (NLRs, del inglés NOD-like receptors), entre otros ${ }^{27}$.

En general, el lipopolisacárido de las bacterias gram negativas es reconocido por los receptores TLR4 y MD-2, pero la especial estructura que presenta el lípido A del LPS de Francisella tularensis hace que la producción de citocinas desencadenada por TLR4 sea mucho más débil que en otras bacterias gram negativas, como por ejemplo E. coli ${ }^{23}$. Induciéndose únicamente bajos niveles de citocinas proinflamatorias, interleucinas (IL)-1 $1 \beta$ y factor de necrosis tumoral $\alpha(\mathrm{TNF} \alpha)^{21,22}$. 
Además de los receptores TLRs, el mecanismo por el que los fagocitos reconocen a las bacterias está compuesto por diferentes receptores en función de las condiciones de opsonización de la bacteria 26,27. Dentro de estos receptores, aquellos que participan en la fagocitosis no opsónica son menos conocidos, aunque se puede destacar el papel de los receptores de manosa de los macrófagos (un tipo de receptores de Lectina tipo C). Por su parte, los receptores que intervienen en la fagocitosis opsónica son: receptores del sistema del complemento, concretamente CR3 (CD11b/CD18) en macrófagos y CR4 (CD11c/CD18) en células dendríticas, receptores scavenger A (SRA), receptores $\mathrm{FC}$ gamma $(\mathrm{FC} \gamma \mathrm{R})$ y nucleolina ${ }^{26,27}$.

\section{- Formación del fagosoma}

Después de haber sido fagocitadas por los macrófagos, quedan incluidas en un fagosoma (FCP, del inglés Francisella-containing phagosome), dicho fagosoma adquiere de manera transitoria ciertos marcadores del endosoma precoz (EE, del inglés Early Endosome) y tardío (LE, del inglés Late Endosome), como son EEA-1, CD63 y LAMP-1, señal de un correcto proceso de maduración ${ }^{27,28}$.

Sin embargo, el fagosoma FCP no se unirá a los lisosomas, impidiendo por un lado que los lisosomas viertan los enzimas lisosomales al FCP y por otro lado la formación del fagolisosoma, por lo que no se procederá a la eliminación de la bacteria fagocitada. Se sabe que el proceso de maduración del FCP ha comenzado porque se produce una ligera acidificación del medio, consecuencia de la liberación de ATPasa. Aunque existen discrepancias sobre cómo actúa el FCP frente a esta acidificación, no obstante, no existen dudas sobre la importancia de la etapa de formación del fagosoma en el ciclo intracelular de Francisella ${ }^{27,28}$.

Mientras la bacteria se encuentra en el fagosoma, la enzima NADPH oxidasa se encarga de producir y liberar especies reactivas de oxigeno con capacidad bactericida (ROS, del inglés Reactive Oxygen Species) a través de la explosión respiratoria. Para asegurar su supervivencia, Francisella tularensis 
reacciona a dicho ataque interrumpiendo activamente la generación de ROS mediante la alteración de dos pasos en la activación de la NADPH oxidasa (inhibiendo el ensamblaje del flavocitocromo $b_{558}$ y mediante la inhibición de la fosforilación de $\mathrm{p} 47^{\text {phox }}$ y $\left.\mathrm{p} 40^{\text {phox }}\right)^{27}$.

También varios de los determinantes de virulencia de Francisella contribuyen mejorando su resistencia al efecto de los ROS (fosfatasas ácidas como AcpA, genes implicados en la biosíntesis de pirimidinas como carA, carB y pyrB, subunidades de la enzima superóxido dismutasa como sodB y sodC, o catalasas como KatG) ${ }^{27,29}$.

\section{- Evasión del fagosoma}

Dentro del ciclo de vida intracelular de Francisella el siguiente paso es la salida del fagosoma. Se ha comprobado que las bacterias tardan entre 1 y 8 horas tras la infección en abandonar el fagosoma y acceder al citosol, diversos factores contribuyen a que este tiempo sea mayor o menor; por ejemplo, en la fagocitosis no opsónica la salida es más rápida que en la opsónica ${ }^{27}$.

Todavía no está claro de qué manera se rompe la membrana del fagosoma. Sin embargo, se sabe que Francisella tularensis expresa un sistema de secreción de tipo VI (T6SS) el cual está codificado por genes de la isla de patogenicidad de Francisella (FPI). Un gran número de estos genes relacionados con el sistema de secreción tienen importancia en la evasión del fagosoma. Entre los genes implicados se encuentran: igC, igD, $p d p A$, ig1l, ig1J, vgrG, dotU, $m g l A$, fevR y $m i g R^{27-29}$.

Existen otros determinantes no relacionados con FPI que podrían estar implicados en la evasión del fagosoma (fosfatasas ácidas o genes implicados en la biosíntesis de pirimidinas) ${ }^{27-29}$. 


\section{- Replicación en el citosol}

Francisella pertenece al grupo de bacterias que se multiplican exclusivamente en el compartimento citosólico de las células infectadas. La capacidad de Francisella tularensis para multiplicarse en el citosol de las células está íntimamente relacionada con la patogenicidad de la bacteria.

Los factores bacterianos que se requieren específicamente para el crecimiento en el citosol no son muy claros, aunque se cree que pueden intervenir factores como genes implicados en la biosíntesis de purina (purMCD), gamma glutamil transpeptidasa (ggt) y diversos genes de función desconocida (FTT0369c/dipA) ${ }^{27}$.

Una vez en el citosol, Francisella tularensis necesita seguir resistiendo a los mecanismos de control del sistema inmune innato, así como adaptar su metabolismo a las restricciones nutritivas del medio. Se ha descubierto que Francisella tularensis utiliza glutatión como fuente de cisteína intracelular para compensar su auxotrofia por este aminoácido ${ }^{3,29}$.

Entre las medidas de defensa que se ponen en marcha en la célula cuando las bacterias están en el citosol se encuentran la xenofagia y la activación del inflamasoma.

La xenofagia es un proceso selectivo de captura de patógenos intracelulares que utiliza mecanismos similares a los utilizados por la autofagia para la eliminación y reciclado de residuos celulares. Es un proceso que se produce dentro de una vacuola para la eliminación microbiana por los lisosomas. Al igual que la autofagia, la xenofagia se halla vinculada a las vías de señalización de la inmunidad innata a través de las respuestas celulares patrones moleculares asociados a patógenos (PAMPs). De hecho, la xenofagia regula, y está regulada por los receptores de reconocimiento de patrones (PRRS), tales como receptores de tipo Toll ( $\underline{\mathrm{TLRS}})$, receptores tipo nod (NLRs), receptores tipo RIG-I (RLRs) sensores citosólicos de DNA (CDS ) y genes estimulados por interferon (STING), así como inflamasomas ${ }^{27,29,30 .}$ 
Por otro lado, el inflamasoma es responsable de la activación de los procesos inflamatorios y se ha demostrado que induce la piroptosis celular (una forma altamente inflamatoria de muerte celular programada, apoptosis, que ocurre con mayor frecuencia tras la infección con patógenos intracelulares y es probable que forme parte de la respuesta antimicrobiana). La presencia de Francisella en el citosol es detectada por interferón (IFN) tipo I que activa la proteína AIM2, cuya activación induce la secreción de las citocinas proinflamatorias IL1 $\beta$ y pro-IL18 y a la piroptosis.

- Diseminación a otras células

Después de una multiplicación activa en el citosol de la célula hospedadora, la diseminación de Francisella tularensis a las células adyacentes se produce tras la lisis celular.
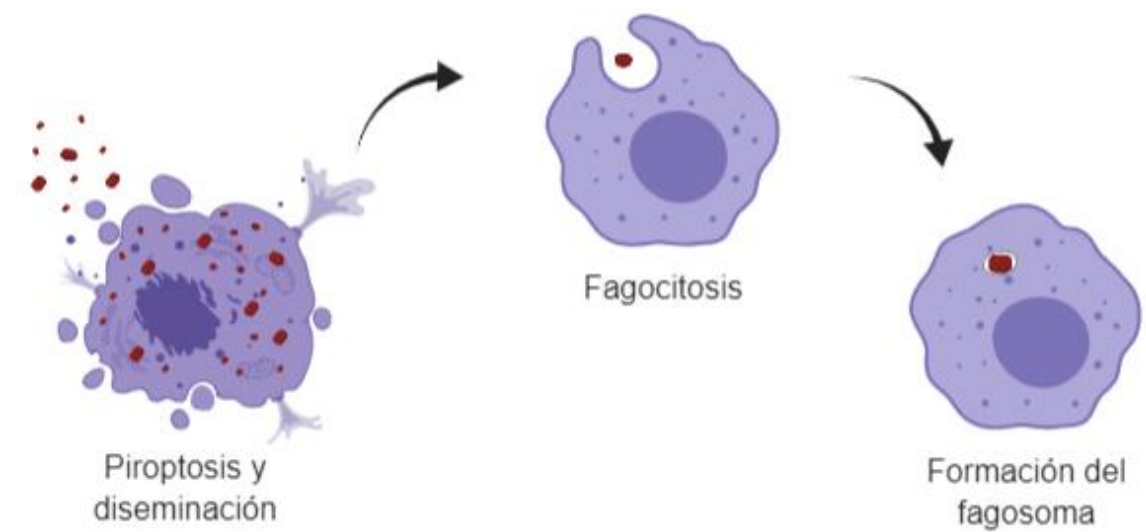

Piroptosis y

Formación del fagosoma

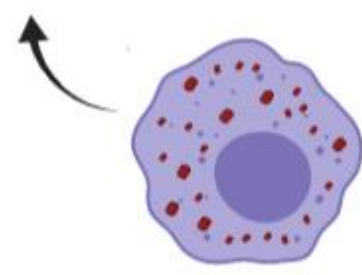

Replicación en el citosol

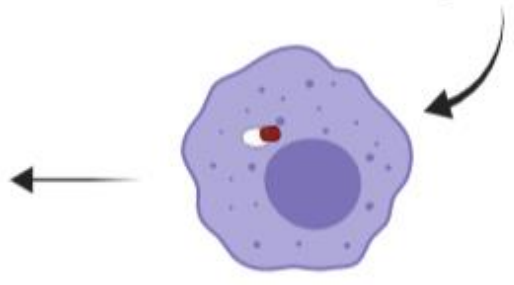

Fuga del

fagosoma

Figura 4: Ciclo de vida intracelular de Francisella tularensis (Elaboración propia) 
La respuesta del organismo humano frente a la infección por Francisella tularensis depende más de la inmunidad celular que de la inmunidad humoral ${ }^{11,31}$. La inmunidad humoral frente los antígenos polisacáridos se produce entre la segunda y la tercera semana tras la infección con la aparición de anticuerpos de clase $\lg \mathrm{M}, \lg G$ e $\lg \mathrm{A}$, con un rol insuficiente para proteger por ellos mismos la infección por Francisella ${ }^{3,11}$.

Por su parte, la inmunidad mediada por células aparece una semana antes de que los anticuerpos sean detectados y actúa directamente frente a los antígenos proteicos de la bacteria confiriendo protección inmunológica. Los receptores TCR de los linfocitos T no reconocen el antígeno de forma directa, sino que solo pueden reconocer péptidos derivados de las proteínas antigénicas, presentados por moléculas de clase I o II del complejo mayor de histocompatibilidad $(\mathrm{CMH})$, estas moléculas se expresan en la superficie de las células presentadoras de antígenos (CPA) ${ }^{32}$. Concretamente, las moléculas de clase I presentan péptidos que activan los linfocitos T CD8+ o citotóxicos y las moléculas de clase II hacen lo mismo con los linfocitos T CD4+. Los linfocitos T presentan diferentes perfiles funcionales según las citocinas que producen, estos perfiles se inducen mediante las CPA y se desarrollan principalmente en los linfocitos T CD4+. En el caso de Francisella las citocinas que se producen son IFN- $\gamma$, IL-2, IL-17, IL-22 y TNF- $\alpha$ (correspondientes a perfiles Th1 y Th17). Mientras que los linfocitos T CD8+ se encargan de mediar la respuesta citotóxica y la producción de citocinas proinflamatorias (IFN-y y TNF- $\alpha)^{31}$.

La inmunidad mediada por células tiene una respuesta diferenciada en función de la vía de entrada de las bacterias, aspecto muy importante en el desarrollo de nuevas vacunas. Diversos estudios han mostrado que las diferentes cepas de Francisella tularensis inducían diferentes formas de inmunidad en función de la vía de entrada ${ }^{31,33}$. Así se observó que los ratones infectados por vía intradérmica o subcutánea presentaban la aparición inmediata de inflamación en los primeros dos días post-infección, mientras que cuando la infección se producía por vía respiratoria, la respuesta se retrasaba hasta 3-5 días, produciéndose en este período de tiempo una intensa multiplicación y acúmulo de microorganismos en hígado y bazo ${ }^{31,33}$. 


\section{Cuadros clínicos}

En general, la gravedad del cuadro clínico de la enfermedad y su forma de presentación dependerán de varios factores ${ }^{3}$ :

- La virulencia de la subespecie causante de la infección, siendo más grave el cuadro clínico cuando está producida por Francisella tularensis subsp. tularensis.

- La puerta de entrada al organismo: solo son necesarias de 10 a 50 bacterias para producir enfermedad si se inyectan vía intradérmica o se inhalan, pero hacen falta $10^{8}$ bacterias cuando se ingieren dada su sensibilidad al ácido.

- La extensión de la afectación sistémica y el estado inmunitario del hospedador. Lo que provocará que el cuadro clínico pueda variar desde una enfermedad asintomática hasta sepsis aguda y fallecimiento ${ }^{3}$.

El tiempo de incubación de la enfermedad suele ser de 3-5 días, variando entre 1 y 21 días el tiempo transcurrido desde la exposición al patógeno a la aparición de los primeros síntomas ${ }^{3,34}$. En el caso de inoculación cutánea, durante los primeros 3-5 días se produce la multiplicación a nivel local produciendo una pápula, y entre 2 y 4 días más tarde comienza la ulceración ${ }^{3}$.

Teniendo en cuenta que Francisella se desarrolla intracelularmente en las células que la fagocitan, la diseminación de las bacterias una vez provocan la piroptosis celular hace que se produzca una bacteriemia durante las fases tempranas de la enfermedad ${ }^{3}$.

Los signos y síntomas generales son fiebre, escalofríos, cefalea, malestar, anorexia y fatiga. También puede aparecer tos, mialgias, molestias torácicas, vómitos, dolor faríngeo, dolor abdominal y diarrea 3,6,11,35.

La fiebre (generalmente $>38,3^{\circ} \mathrm{C}$ ) suele durar varios días, remite durante un intervalo corto y después recidiva. Las cepas menos virulentas causan una enfermedad más leve y autolimitada ${ }^{3,36}$. 
Suele existir confusión en el diagnóstico por dos razones ${ }^{3,11}$ :

1) Los síntomas sistémicos pueden haber desaparecido cuando se solicita ayuda médica, quedando únicamente las manifestaciones del cuadro clínico concreto.

2) El $25-50 \%$ de los pacientes no presentan un origen evidente de la infección.

Además de por los síntomas generales, la tularemia se caracteriza por presentar un cuadro clínico asociado a la puerta de entrada de las bacterias.

\section{$\underline{\text { Ulceroglandular o ulceroganglionar }}^{3,19,21,37,38}$}

- Incidencia: presentación más frecuente de la enfermedad.

- Vía de contagio: picaduras de garrapata y contacto con animales contaminados.

- Síntomas frecuentes: linfadenopatía localizada y sensible a la palpación; de manera anterior, simultánea o posterior aparece una lesión cutánea que comienza como una pápula eritematosa y dolorosa en una región que drena en los ganglios linfáticos. Posteriormente se necrosa y deja una úlcera hipersensible con el borde elevado.

- La localización de la lesión se relaciona con el modo de adquisición:

- Contacto con animales: úlceras en manos y antebrazos.

- Picadura de garrapata: úlceras en tronco, periné, extremidades inferiores, cabeza y cuello.

- Complicaciones: linfangitis infrecuente (a menos que exista una sobreinfección bacteriana).

\section{Glandular o ganglionar $^{3,19,21,37,39}$}

- Síntomas frecuentes: linfadenopatía regional sensible a la palpación, pero sin lesión cutánea evidente (constituye el mismo proceso que la enfermedad ulceroglandular). 
- El aumento de tamaño de los ganglios linfáticos puede persistir durante periodos prolongados.

- Complicaciones: más del $20 \%$ de los ganglios linfáticos supuran si no se tratan o si el tratamiento se retrasa más de 2 semanas.

\section{Oculoglandular u oculoganglionar $3,19,21,37,40$}

- Incidencia: número mínimo de casos.

- Vía de contagio: se contagia a través de la conjuntiva por el contacto de los dedos contaminados o salpicaduras y aerosoles.

- Síntomas frecuentes: fotofobia y lagrimeo, edema palpebral, conjuntivitis dolorosa con inyección, quemosis, úlceras o pápulas conjuntivales. Dado el carácter de distribución orgánica de Francisella pueden aparecer linfadenopatías (preauricular, submandibular y cervical).

- Complicaciones: pérdida de visión excepcional, ulceración corneal, dacriocistitis y supuración ganglionar.

\section{Faríngea $3,19,21,37,41-44$}

- Incidencia: suele ser más frecuente en niños que en adultos.

- Vía de contagio: consumo de alimentos o agua contaminados.

- Síntomas frecuentes: fiebre e intenso dolor faríngeo (faringitis o amigdalitis exudativa con una o más úlceras). Pueden aparecer linfadenopatías (preparotídeas, retrofaríngeas y cervicales).

\section{Tifoídica ${ }^{3,19,21,37}$}

- Enfermedad febril no asociada a linfadenopatía (ni a ninguna de las formas de presentación).

- Vía de contagio: puede deberse a cualquier modo de adquisición y es de difícil diagnóstico. 
- Síntomas frecuentes: fiebre con escalofríos, cefalea, mialgias, dolor faríngeo, anorexia, náuseas, vómitos, diarrea, dolor abdominal y tos.

- Complicaciones: son difusas y de gravedad variable.

\section{Neumónica $^{3,19,21,37,45}$}

- Vía de contagio: inhalación directa de las bacterias o propagación hematógena secundaria al pulmón.

- Presentación inicial: como una infección pulmonar en cualquiera de los dos casos.

- La neumonía primaria supone un riesgo para determinadas profesiones (esquiladores, granjeros, jardineros).

- Mientras que la secundaria se puede producir pronto o tras el lapso de semanas o meses.

- Síntomas frecuentes: tos, fiebre, producción de esputo nula o mínima, tensión subesternal y dolor torácico pleurítico. Entre un 25 y 30\% de los pacientes tienen infiltrados en las radiografías sin ningún signo clínico de neumonía.

- Complicaciones: puede desarrollarse de manera secundaria a cualquiera de las otras formas de la enfermedad, aunque lo más frecuente es que afecte a las formas tifoídica (83\%) y ulceroglandular (31\%).

- El análisis habitual del esputo no ayuda a establecer el diagnóstico.

\section{Epidemiología}

\subsection{Reservorios y especies susceptibles de padecer tularemia}

Francisella tularensis infecta a cientos de especies de vertebrados e invertebrados, pero solo algunas de estas especies pueden ser fuente de infección para el hombre, siendo más frecuente que sean animales silvestres 
(por ejemplo lagomorfos o roedores), aunque también se han dado casos en los que han intervenido animales domésticos $3,5,15,46,47$.

Dentro de la división de los vertebrados se pueden destacar las siguientes órdenes de animales como principales afectados por la enfermedad:

- Lagomorfos: dentro de la familia Leporidae, los géneros Sylvilagus y Lepus spp ${ }^{3,15,48}$.

- Roedores: incluye numerosas familias diferentes (Sciuridae, Castoridae, Hystricidae, Myocastoridae, Gliridae, Spalacidae, Cricetidae, Muridae), entre las que destacan ratones, topillos, ardillas, ratas almizcleras, castores y hámsteres como fuente de infección del hombre en el medio natural. En España principalmente topillos campesinos (Microtus arvalis) ${ }^{3,15}$.

En el grupo de invertebrados son abundantes los artrópodos que se comportan como vectores de la infección, destacando al menos 13 especies de garrapatas de la cuales algunas poseen la capacidad de transmisión transovárica de Francisella actuando a su vez como reservorios 3,5,8,15,49. También los mosquitos y tábanos, y de manera más excepcional, se han notificado brotes provocados por cangrejos de río ${ }^{50-52}$.

La importancia que tienen los artrópodos en la difusión de la enfermedad es manifiesta, ya que las garrapatas son el vector principal en Estados Unidos, y los mosquitos lo son en Suecia y Finlandia $3,5,53$.

Por otra parte, Francisella tularensis puede sobrevivir durante largos periodos de tiempo en el agua pudiendo afectar incluso a diferentes especies de protozoos, donde es capaz de desarrollarse intracelularmente ${ }^{54}$.

\subsection{Modos de transmisión}

La baja dosis infectante de Francisella tularensis (10-100 UFC) hace que la transmisión de la infección a humanos sea relativamente sencilla ${ }^{11}$. Dicha infección se produce mediante diversos mecanismos, entre los que destacan: 
a) Contacto directo con reservorios o animales fuente de infección de la enfermedad: bien sea en la manipulación de animales infectados o por mordedura de los mismos 11,13,15.

b) Agua contaminada: por contacto directo o por su consumo. Normalmente el agua se suele contaminar por la presencia del cadáver de algún animal infectado 11,13,15.

El hecho de que la bacteria pueda sobrevivir en el agua a temperaturas de entre 13 y $15^{\circ} \mathrm{C}$ durante varios meses permite una mayor capacidad de transmisión ${ }^{3,13}$. Un caso particular es la manipulación de los cangrejos de río infectados o que presentan amebas infectadas por Francisella en su caparazón 52.

c) Inhalación de partículas infecciosas: uno de los mecanismos más frecuentes tiene lugar durante el desollado de animales enfermos y la inhalación de aerosoles que se producen durante dicho desollado ${ }^{3,36}$. También por actividades cotidianas como cortar el césped 0 manipular hierba si están contaminados por heces o cadáveres de animales infectados, o bien durante la utilización de cosechadoras $11,13,45,55$.

d) Picadura de garrapata, mosquito u otro insecto contaminados: puesto que estos tienen una mayor reproducción durante los meses de primavera-verano se ha relacionado este hecho con una mayor incidencia de la enfermedad durante esos meses ${ }^{5,13}$.

No se considera al hombre como fuente de infección ni reservorio de la enfermedad ya que no se han descrito casos de transmisión interhumana ${ }^{5,11}$. Tradicionalmente la enfermedad afecta a personas de todas las edades, no presentando un patrón de distribución asociado a la edad ${ }^{5,13,56}$.

Se aprecia una mayor incidencia en varones, que se relaciona con las profesiones desarrolladas al aire libre o actividades de ocio en el campo en contacto con reservorios o vectores de la enfermedad, actividades que habitualmente están más arraigadas en la población masculina ${ }^{11,13}$.

Dentro de las actividades que pueden facilitar el contacto con Francisella se incluyen: cazadores de liebres y otros animales fuente de infección de la 
enfermedad, agricultores que puedan estar en contacto con cadáveres de animales contaminados o con sus excrementos, guardabosques, jardineros, veterinarios y manipuladores de alimentos $3,13,57,58$. Sin olvidar por supuesto al personal de laboratorio que trabaja con las bacterias ${ }^{59-62}$.

\subsection{Distribución geográfica}

La enfermedad predomina en el hemisferio norte (entre los 30 y $71^{\circ}$ Norte) ${ }^{4,46,63-65}$. Los continentes más afectados son: América, Europa y Asia; por lo que son muy llamativos los casos que se han descrito en Australia, entre los que destacan los ocurridos en el año 2003 por una bacteria que por características genotípicas y fenotípicas pertenecería a Francisella tularensis subsp. novicida, pero en la que determinadas diferencias en la secuenciación de los genes 16S rRNA sugieren clasificarla como una forma atípica de $F$. tularensis subsp. novicida o como una nueva subespecie; y en el año 2011 en la región de Tasmania por mordedura de un marsupial infectado con Francisella tularensis subsp. holarctica 66,67. En 2017 se consiguió aislar bacterias de esta subespecie en zarigüeyas, lo que confirmaría la presencia de Francisella tularensis en Oceanía ${ }^{68}$.

También en África, concretamente en Kenia, se han encontrado anticuerpos frente a Francisella tularensis en pacientes en los que no se diagnosticó la enfermedad, aunque en este caso hay que tener en cuenta la comunidad antigénica entre Francisella spp. y otras bacterias ${ }^{5,37,69}$.

\section{a) América}

En el caso de América, aunque se han descrito casos en países como México o Canadá, la tularemia tiene una mayor incidencia en Estados Unidos.

Como ya se ha mencionado anteriormente la tularemia fue descubierta a principios del siglo $\mathrm{XX}$ en los Estados Unidos. A pesar de que el número de 
casos ha disminuido progresivamente desde los años 50 (el año de mayor incidencia de la enfermedad fue 1939 con 2291 casos diagnosticados), en la actualidad se notifican una media de entre 125 y 200 casos al año (Figura 5). A pesar de que puede darse en forma de brotes la mayoría de los casos notificados se presentan de forma aislada ${ }^{70-74}$.

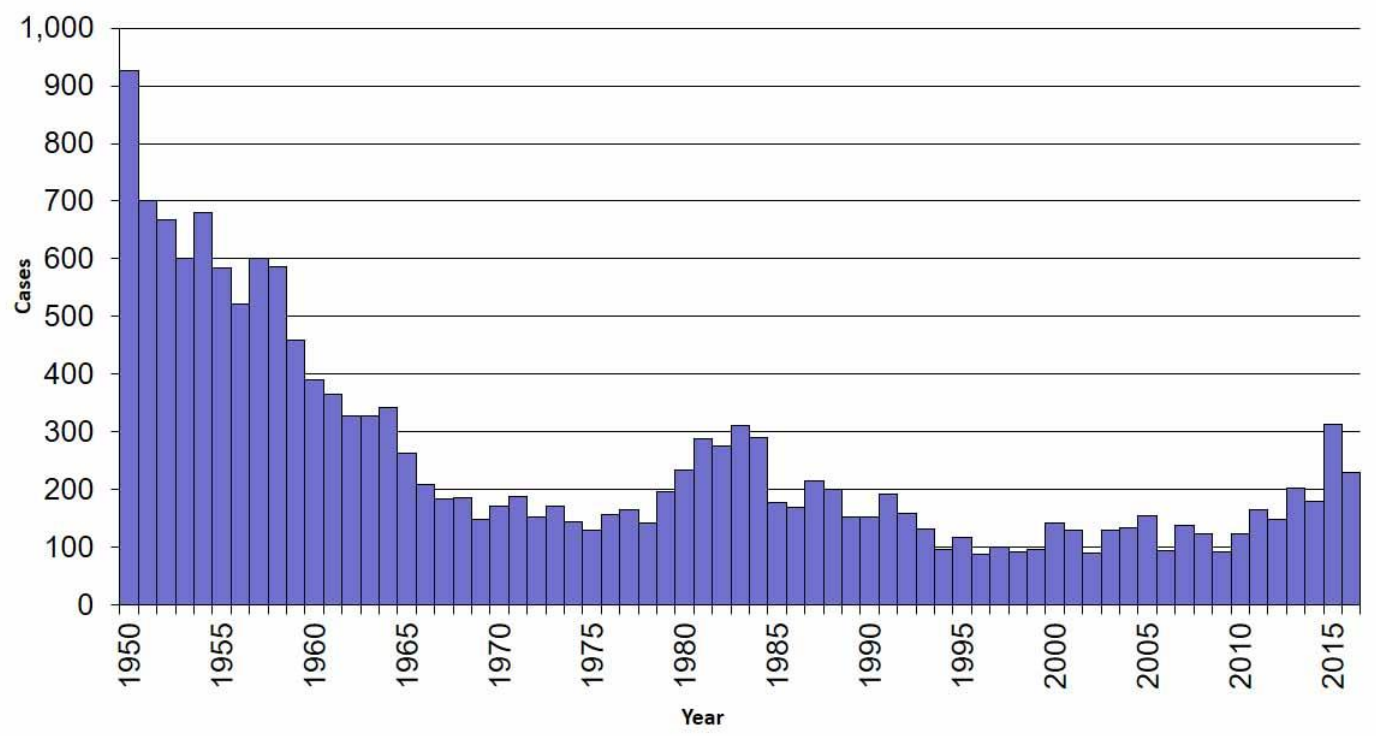

Figura 5: Número de casos notificados anualmente de tularemia en EE. UU. (1950-2016) (Imagen tomada del $\mathrm{CDC}^{75}$ )

Dada la disminución de incidencia observada durante la segunda mitad del siglo XX la tularemia fue eliminada de la lista de enfermedades de declaración obligatoria en EEUU en el año 1994, pero vuelta a incluir en el año 2000 por su posible uso como arma biológica ${ }^{73,74}$.

Se han notificado casos de tularemia en todo los estados excepto en Hawái, y de los datos publicados durante los últimos 25 años se puede extraer un patrón de incidencia que afecta principalmente a estados del Medio Oeste de los Estados Unidos y zonas limítrofes a dicha área ${ }^{73,74}$.

Según los artículos emitidos por el CDC (Centers for Disease Control and Prevention) el 56\% de los casos declarados entre 1990 y 2000 se concentran en 4 estados: Arkansas, Missouri, South Dakota y Oklahoma ${ }^{73}$. Mientras que entre 2001 y 2010 son el $59 \%$ de los casos declarados los que se 
distribuyen por los estados de: Missouri, Arkansas, Oklahoma, Massachusetts, South Dakota y Kansas (Figura 6.a.) y el 61,5\% en 2017 (Figura 6.b.) ${ }^{74}$. Lo que demuestra una mayor incidencia de la enfermedad en zonas rurales.
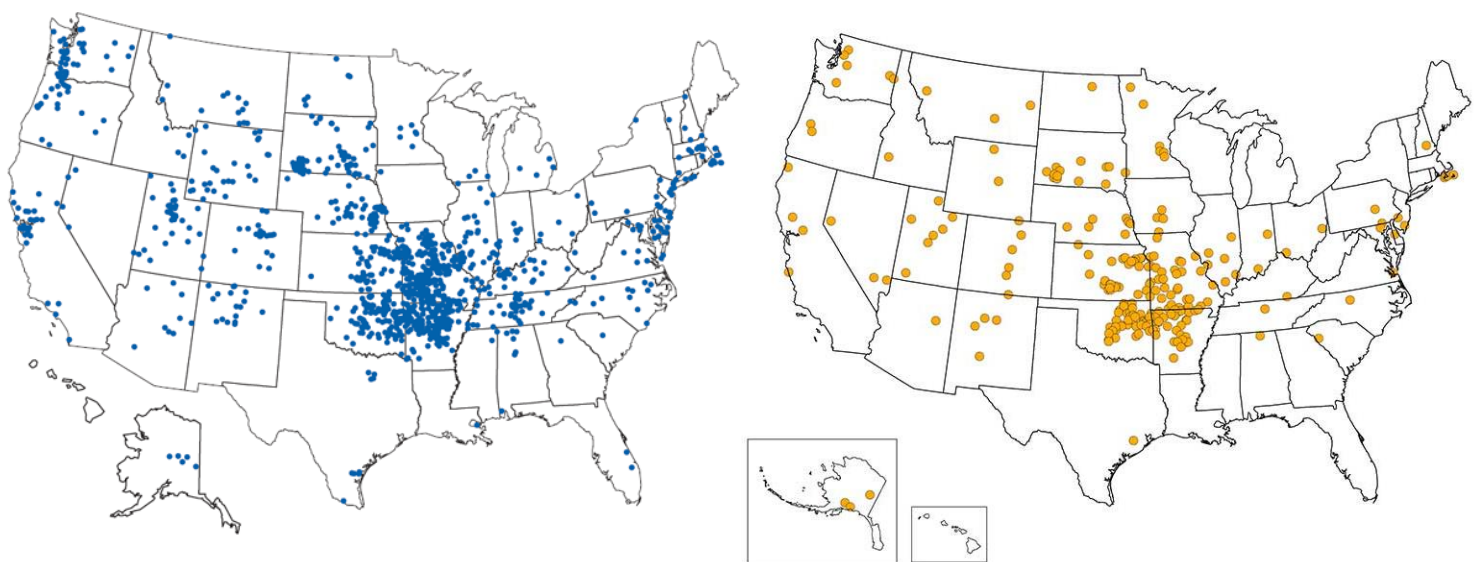

Figura 6: Mapa de casos notificados de tularemia en EE. UU. entre 2001 - 2010 (6.a.) y en 2017 (6.b) (Imágenes tomadas del $\mathrm{CDC}^{74}$ )

Cabe destacar los casos registrados en el estado de Massachusetts, concretamente los brotes ocurridos en la isla de Martha's Vineyard en el condado de Dukes en los años 1978 y 2000, pues corresponden a los únicos casos de tularemia expresada de forma neumónica en los Estados Unidos $45,49,55,76,77$. Diversos estudios han demostrado que varios de los sujetos infectados se dedicaban a la jardinería, relacionándose directamente con posibles aerosoles contaminados que pudieron inhalar en actividades cotidianas como cortar el césped o manipular hierba ${ }^{11,45,55}$.

Nuevos estudios han verificado que "Dermacentor variabilis" (garrapata americana del perro) puede ser la fuente de infección y el reservorio de la bacteria en la isla $49,76,77$. 
Normalmente la enfermedad se suele presentar en las formas ulceroglandular y glandular; y aunque se notifican casos durante todos los meses del año (principalmente asociados a mordedura de artrópodos durante los meses de verano y por contacto con mamíferos infectados en invierno), más del $70 \%$ corresponden al periodo de tiempo entre mayo y septiembre $71,73,74$.

\section{b) Europa}

En Europa predomina Francisella tularensis subsp. holarctica, también se han aislado cepas de Francisella tularensis subsp. tularensis en vectores de Europa del este, zonas cercanas a Bratislava (Eslovaquia) y en Austria 15,17,1815.

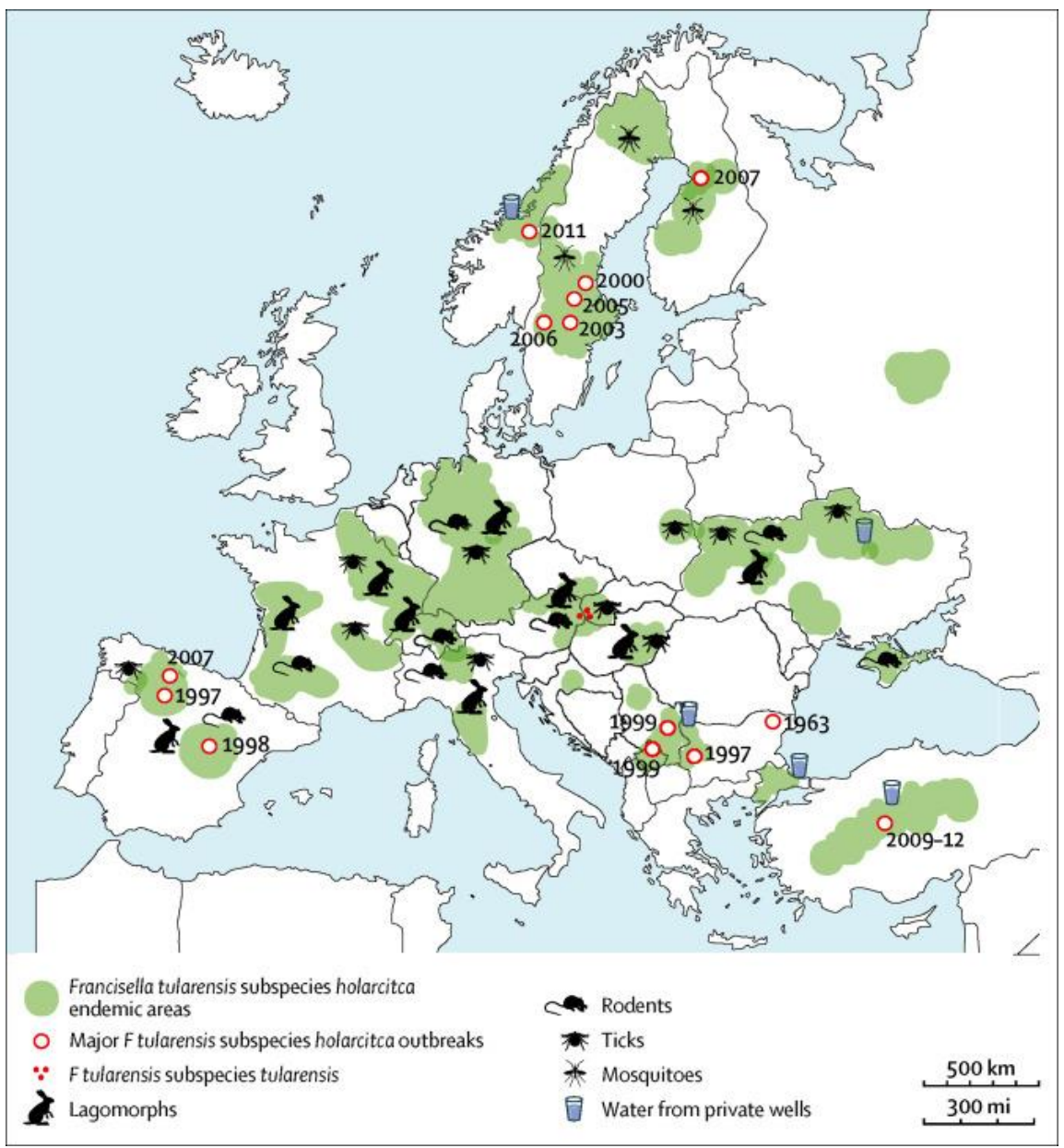

Figura 7: Mapa de zonas endémicas, reservorios y principales brotes de tularemia en Europa (Imagen tomada de Maurin et al. ${ }^{15}$ ) 
A pesar de ello las características de la enfermedad varían de unos territorios a otros. En la siguiente tabla se muestra cómo la incidencia de la enfermedad difiere significativamente entre los diversos países de Europa, pudiendo encontrarse países libres de tularemia en la proximidad inmediata con regiones endémicas.

Tabla 1: Tabla de incidencia de tularemia por países en Europa

\begin{tabular}{|c|c|}
\hline INCIDENCIA & PAÍSES \\
\hline Sin datos ${ }^{15}$ & $\begin{array}{l}\text { Andorra, Liechtenstein, Moldavia, Mónaco, Montenegro, } \\
\text { San Marino y Vaticano }\end{array}$ \\
\hline Sin tularemia ${ }^{15}$ & $\begin{array}{l}\text { Chipre, Grecia, Islandia, Irlanda, Letonia, Luxemburgo, } \\
\text { Macedonia, Malta y Reino Unido }\end{array}$ \\
\hline $0-0,1 / 100000$ & $\begin{array}{l}\text { Albania }{ }^{15} \text {, Bélgica }{ }^{15} \text {, Bosnia y Herzegovina }{ }^{15} \text {, Dinamarca } \\
{ }^{78} \text {, Alemania }{ }^{79-82} \text {, Italia }{ }^{83} \text {, Suiza }{ }^{84,85} \text {, Países Bajos }{ }^{86-88} \text {, } \\
\text { Polonia }{ }^{63} \text {, Portugal }{ }^{89} \text {, Georgia }{ }^{90} \text {, Rumanía }{ }^{15} \text { y Eslovenia }{ }^{15}\end{array}$ \\
\hline $1 / 100000$ & $\begin{array}{l}\text { Austria }{ }^{91} \text {, Croacia }{ }^{15} \text {, Estonia }{ }^{15} \text {, Francia }{ }^{35,92-94} \text {, Lituania }{ }^{15} \text {, } \\
\text { Ucrania }{ }^{95} \text { y Serbia }{ }^{41}\end{array}$ \\
\hline$>1 / 100000$ & $\begin{array}{l}\text { Suecia }{ }^{51,53,96-101} \text {, Finlandia }{ }^{102-104} \text {, Noruega }{ }^{105-107} \text {, Bulgaria } \\
108,109 \text {, República Checa }{ }^{110-112} \text {, Hungría }{ }^{113,114} \text {, Kosovo }{ }^{115-} \\
{ }^{118} \text {, Rusia }{ }^{119-121} \text {, Eslovaquia }{ }^{17,18} \text { y España }{ }^{36,52,56,122-126}\end{array}$ \\
\hline
\end{tabular}

Aunque en todo el continente europeo la bacteria causante de tularemia es Francisella tularensis subsp. holarctica; el modo de transmisión de la enfermedad a los humanos, así como los vectores implicados en dicha transmisión marcan diferencias cualitativas entre las manifestaciones clínicas de la enfermedad en los diferentes territorios endémicos.

Las diferencias entre regiones se manifiestan de la siguiente forma: 
1) Países Nórdicos: tanto Noruega como Suecia y Finlandia presentan una elevada incidencia de tularemia, llegando a encontrar regiones con hasta 37 casos/100 000 habitantes en Finlandia 104, 62,7 casos/100 000 habitantes en Noruega ${ }^{107}$ y 7,78 casos/100 000 habitantes en Suecia ${ }^{98}$.

Sin embargo, la forma de transmisión y, por ende, la forma clínica de la enfermedad presenta significativas diferencias. Mientras que en Suecia y Finlandia el vector principal de la enfermedad es el mosquito 15,51,53,96. En Noruega los casos relacionados con mosquitos son casi inexistentes y en su lugar aparecen con frecuencia brotes producidos por el consumo de agua contaminada ${ }^{15,106,107}$.

El consumo de agua contaminada provoca que la forma orofaríngea sea la más común en Noruega con más del $40 \%$ de los casos confirmados en el brote del año 2011, con una distribución estacional mayoritaria en invierno y primavera ${ }^{127}$.

Por su parte, Suecia y Finlandia presentan una mayor incidencia de la enfermedad durante los meses de verano y otoño, los cuales coinciden con un repunte en la población de mosquitos en la zona, y se manifiesta principalmente en las formas ulceroglandular y glandular 15,50,96,102.

2) Península Balcánica: aunque se habían detectado casos aislados con anterioridad, la presencia de tularemia en las regiones balcánicas no se hizo destacable hasta la década de $1990{ }^{128}$.

En Kosovo no se había notificado ningún caso de tularemia antes del año 1999, pero entre 1999 y 2000 se dieron cerca de 700 casos en dos brotes que afectaron a diferentes áreas del país con una forma de presentación generalmente orofaríngea ${ }^{15,115}$.

En este caso, y dada la cercanía del final de la guerra, se relacionó el origen de la enfermedad con la falta de medidas higiénico-sanitarias derivada del conflicto, pudiendo producirse la contaminación de agua y alimentos de consumo por parte de roedores infectados ${ }^{15,116,117}$. 
A partir de estos brotes la enfermedad ha seguido presente en el país con mayor o menor incidencia durante el siglo XXI ${ }^{118}$.

Pero no solo Kosovo presenta una elevada incidencia de la enfermedad dentro de los países balcánicos, también Bulgaria tiene una ratio de más de 1 caso/100 000 habitantes desde el año $1997{ }^{108}$.

En este caso el contagio se ha relacionado con el consumo de agua contaminada, lo que provoca que más del $95 \%$ de los casos sean en forma orofaríngea ${ }^{15,108}$.

Tanto la proximidad de este brote con la frontera de Serbia, así como las similitudes en el genotipo con el de las bacterias encontradas en Turquía permiten plantear la hipótesis de un posible origen común, pero diferente al de Kosovo ${ }^{128}$.

3) España: para detallar la situación de la enfermedad en nuestro país el Ministerio de Sanidad, Servicios Sociales e Igualdad, a través del Centro de Coordinación de Alertas y Emergencias Sanitarias (CCAES), elaboró en 2013 el "Informe de situación y evaluación del riesgo de la tularemia en España". En el cual se exponen todos los detalles epidemiológicos de la enfermedad, así como los brotes ocurridos en España y un análisis del futuro riesgo.

Si bien la tularemia en humanos en España solo había presentado casos aislados hasta el año 1997, a partir de entonces se han descrito tres grandes brotes con características epidemiológicas muy concretas y diferentes.

- Brote en Castilla y León de 1997: entre noviembre de 1997 y abril de 1998 se notificaron 559 casos de tularemia humana, no obstante el número de casos reales fue muy superior ya que la información que se pudo obtener fue bastante reducida debido a que la tularemia no constaba en los protocolos de Enfermedades de Declaración Obligatoria (EDO) en ese momento. 
Aparecieron casos en 10 Comunidades Autónomas, aunque ninguna de ellas presentó casos autóctonos salvo Castilla y León, comunidad donde se originaron las infecciones y donde además se declararon la mayoría de los casos con 513 pacientes infectados. Los 559 casos se desglosan en 101 sospechosos (pacientes que únicamente cumplen los criterios clínicos y/o epidemiológicos de diagnóstico) de los cuales 92 son de Castilla y León, 390 casos probables (368 en Castilla y León) y 66 confirmados (53 en Castilla y León).

El brote se originó en el contexto de una epizoonosis que afectó fundamentalmente a las liebres y que dejó entre 15000 y 20000 animales muertos en la comarca de Tierra de Campos (región que engloba territorios de Palencia, Valladolid, Zamora y León). Dicho brote se transmitió a humanos a través del contacto directo con liebres enfermas, bien fuese consecuencia de su caza, del desollado o de la ingesta de carne contaminada. Debido a la forma de contagio de la enfermedad, todos los pacientes encuestados presentaban antecedentes de manipulación de liebres y ninguno refirió picaduras de garrapatas. Se manifestó principalmente en las formas clínicas ulceroglandular y glandular (un $70 \%$ de los casos presentaron estos síntomas) y afectó principalmente a cazadores. Sin embargo hubo un número importante de casos de tularemia neumónica que afectó principalmente a las mujeres como consecuencia de los aerosoles producidos durante el desollado de las liebres ${ }^{13,15,36}$.

Un estudio llevado a cabo por nuestro departamento demostró que previamente al brote epidémico ya existían anticuerpos específicos frente a Francisella tularensis en los habitantes de la región, encontrando 9 sueros positivos entre una muestra de 4825 sueros recogidos con anterioridad al primer brote de tularemia en Castilla y León ${ }^{122}$. 
- Brote en Cuenca de 1998: muy cercano en fecha con el de Castilla y León. En este caso, aunque la forma de presentación de la enfermedad también fue mayoritariamente ulceroglandular, el contagio se produjo por la pesca y manipulación de cangrejos de río contaminados en Moncalvillo de Huete (Cuenca), a orillas del Río Mayor. Se confirmaron 19 casos (11 hombres y 8 mujeres) que habían tenido contacto con cangrejos de río pescados entre el 13 y el 31 de Julio de 1998. En las investigaciones posteriores se tomaron diversas muestras para analizar (incluidas muestras de los cangrejos, agua de diferentes zonas del río y de una depuradora cercana, así como de diferentes especies animales de la zona), se encontraron cepas de Francisella tularensis subsp. holarctica en los cangrejos y el agua de la depuradora. Esta contaminación del agua del río probablemente se produjo por el cadáver de alguna liebre. La transmisión al hombre se produjo durante la manipulación de los cangrejos debido a las lesiones cutáneas originadas con los caparazones contaminados de los crustáceos. Dicho proceso tuvo lugar durante un periodo de tiempo limitado y en un tramo corto del río puesto que no se dieron casos de la forma orofaríngea que implicaría una forma de infección por el contacto o consumo de agua contaminada ${ }^{13,15,52}$.

- Brote en Castilla y León en 2007: debido a que en 2007 la tularemia ya constituía una Enfermedad de Declaración Obligatoria, la información que se tiene de este brote es mucho más detallada que en los anteriores. Se contabilizaron en total 507 casos confirmados registrados oficialmente, de los cuales el $90 \%$ ocurrieron entre las semanas 25 (18 de junio) y 43 (22 de octubre), aunque el pico de incidencia fue entre la semana 26 (25 de junio) y 33 (18 de agosto) con un $59,5 \%$ de los casos. La provincia más afectada fue Palencia con 278 casos confirmados, seguida de Zamora (69), Valladolid (61) y León (49). 
Si el primer brote la enfermedad se relacionó con liebres enfermas y el segundo con cangrejos de río contaminados, el brote de 2007 tiene relación muy estrecha con una plaga de topillos (Microtus arvalis) que asoló durante 2007 y 2008 fundamentalmente la zona de Tierra de Campos que, a su vez, fue la más afectada por la epidemia de tularemia. La población de topillos llegó a alcanzar niveles de 1350 topillos/hectárea (cuando normalmente hay 5-10 topillos/hectárea).

Estudios posteriores demostraron una significativa relación entre la densidad de población de topillos de ese año y el número de casos de tularemia durante el brote, y que el $2 \%$ de los roedores estaban infectados por la bacteria, así como una prevalencia de liebres afectadas del $34 \%{ }^{13,129}$.

En este caso la enfermedad afectó mayoritariamente a varones $(80,08 \%)$, agricultores o que tuvieron contacto con topillos, y la enfermedad se manifestó en la forma tifoídica $(58,97 \%)$ y neumónica $(7,89 \%)$ en más del $65 \%$ de los casos, lo que lleva a pensar que la forma más frecuente de adquisición fue la inhalación de aerosoles contaminados (por heces y cadáveres de topillos) que se liberaron en diversas tareas agrícolas e infectaron a los seres humanos ${ }^{13,15,56}$.

A pesar de las diferencias en la clínica y la epidemiología de los brotes de la enfermedad en España, se ha demostrado que la diversidad genética de las cepas aisladas en estos periodos es muy baja, lo que demostraría la persistencia de la bacteria en reservorios locales ${ }^{15,126,130}$.

\section{c) Asia}

Como ya se ha indicado anteriormente las cepas de la variedad Francisella tularensis subsp. mediasiatica se han localizado exclusivamente en regiones de Asia central ${ }^{3,9}$. Si nos referimos a Francisella tularensis subsp. holarctica podemos encontrarla en Japón, China y algunas regiones de la parte asiática de Rusia y Turquía. 
En Japón, pese a ser unos de los primeros países donde se describió la enfermedad, en la actualidad la incidencia es de 10 casos notificados al año ${ }^{131}$. Ejemplo similar al de Rusia, donde durante la II Guerra Mundial se llegaron a notificar hasta 100000 casos al año de tularemia, y actualmente se han reducido a unos cientos de casos al año que se localizan principalmente en regiones de la zona de Siberia ${ }^{119,120}$.

Situación opuesta es la de Turquía, país en el que hasta el año 2005 solo se habían producido casos aislados de tularemia en humanos, pero que en los últimos 10 años ha registrado más de 15 brotes que han afectado a regiones distribuidas por todo el territorio ${ }^{132-134}$. La forma de presentación más habitual es la orofaríngea relacionada con el consumo de agua contaminada y con una mayor afectación durante los meses de invierno ${ }^{133}$. Tal es la incidencia que tiene la enfermedad en el país que durante los años 2010 y 2011 el número de casos en Turquía superó al total de casos registrado en todos los países de la Unión Europea juntos ${ }^{132}$.

\section{Diagnóstico}

El diagnóstico clínico se basa en los antecedentes de un mordisco de garrapata o picadura de mosquito, contacto con mamíferos que puedan ser fuente de infección de la enfermedad o exposición a agua potencialmente contaminada.

Según el Centro para el Control y Prevención de Enfermedades del Departamento de Salud y Servicios Humanos de los Estados Unidos (CDC), los criterios diagnósticos para la identificación de tularemia son los siguientes ${ }^{135}$ : 
$\rightarrow$ Caso probable: cuadro clínico compatible con la enfermedad y que presente títulos elevados de anticuerpos (>1:160) frente a Francisella tularensis sin historia de vacunación.

También se puede considerar como caso probable cuando se produzca la detección de Francisella tularensis por inmunofluorescencia sobre la muestra clínica.

$\rightarrow$ Caso confirmado: aislamiento y cultivo de Francisella tularensis en muestras clínicas o que a través de técnicas indirectas se constate un aumento de 4 veces o más en títulos de aglutinación de anticuerpos en suero.

La OMS (Organización Mundial de la Salud) añade como criterio de confirmación para casos de tularemia la obtención de resultados significativos de presencia de anticuerpos frente a Francisella tularensis en pruebas de ELISA ${ }^{11}$.

A nivel nacional la agencia encargada de los protocolos diagnósticos es la Red Nacional de Vigilancia Epidemiológica, según la cual para confirmar un caso de tularemia es necesario que se conjuguen unos criterios epidemiológicos con unos criterios de laboratorio ${ }^{56,136}$.

$\rightarrow$ Criterio epidemiológico (al menos uno de los cuatro):

- Exposición a animales enfermos o muertos por tularemia.

- Exposición a alimentos o agua contaminados.

- Exposición a aerosoles o polvo, en ambientes contaminados por animales sospechosos o enfermos.

- Exposición a artrópodos vectores. 
$\rightarrow$ Criterio de laboratorio (al menos uno de los tres):

- Aislamiento de Francisella tularensis en una muestra clínica.

- Detección del ácido nucleico de Francisella tularensis en una muestra clínica por PCR.

- Respuesta específica de anticuerpos de Francisella tularensis.

Otras administraciones sanitarias de diferentes países emplean criterios diagnósticos similares a los ya mencionados ${ }^{137-139}$.

Podemos clasificar las técnicas de diagnóstico de la tularemia en dos grupos, ya sean de detección directa de las bacterias o indirectas, teniendo en cuenta el riesgo que supone para el personal de laboratorio el cultivo de Francisella tularensis, son las técnicas indirectas o serológicas las más utilizadas.

Tabla 2: Principales técnicas de diagnóstico de tularemia

\begin{tabular}{|c|c|}
\hline Diagnóstico microbiológico directo & $\begin{array}{l}\text { Diagnóstico microbiológico } \\
\text { indirecto } \rightarrow \text { Serología }\end{array}$ \\
\hline Cultivo & \multirow{2}{*}{$\begin{array}{l}\text { Técnicas de aglutinación: } \\
\text { - } \quad \text { Aglutinación en tubo } \\
\text { - Microaglutinación (MAT) }\end{array}$} \\
\hline $\begin{array}{l}\text { Identificación directa del agente: } \\
\text { - Inmunofluorescencia }\end{array}$ & \\
\hline \multirow{2}{*}{$\begin{array}{l}\text { Detección del genoma bacteriano: } \\
\text { - PCR (Polymerase Chain } \\
\text { Reaction) }\end{array}$} & $\begin{array}{l}\text { ELISA (Enzyme-Linked } \\
\text { Inmunosorbent Assay) }\end{array}$ \\
\hline & Inmunocromatografía \\
\hline
\end{tabular}




\section{- Diagnóstico microbiológico directo}

\section{- Cultivo}

Francisella tularensis puede crecer a partir de exudados faríngeos, muestras de esputos, aspirados gástricos, sangre, exudados conjuntivales y de las úlceras ${ }^{10,37}$. Hay que tener en cuenta que es necesario tomar la muestra para su cultivo en fases iniciales de la enfermedad. Normalmente, una vez que aparecen los anticuerpos ya no se consigue su aislamiento.

La tasa de aislamiento es relativamente baja $(5 \%)$, incluso en fases agudas de la enfermedad es difícil de cultivar ${ }^{37}$. El cultivo se puede realizar incluso después de haber comenzado el tratamiento antibiótico, aunque su rendimiento diagnóstico disminuye mucho ${ }^{37}$.

Requiere de medios enriquecidos que contengan cisteína, cistina, u otra fuente de grupos sulfidrilos para crecer. Medios utilizados 5,37 :

- Glucose cysteine agar with thiamine o cysteine blood agar (medio ideal).

- Charcoal Yeast Extract (CYE) (medio habitual).

- Chocolate agar (medio habitual).

- Thayer-Martin agar (medio habitual).

Una vez incubado a $37^{\circ} \mathrm{C}$ se puede observar un crecimiento entre 24 y 48 horas después de inocularlo ${ }^{10,37}$.

Dentro de las técnicas de cultivo se suele evitar la inoculación de Francisella tularensis en animales, pese a tratarse de uno de los métodos más sensibles de diagnóstico. El elevado coste de mantenimiento de los animales, el riesgo de iniciar una epidemia, así como el riesgo que supone para el personal de laboratorio desaconsejan la inoculación experimental como método diagnóstico ${ }^{5}$. Además, para la manipulación de animales infectados se precisan unas instalaciones con un nivel 3 de Bioseguridad para desarrollar esta técnica ${ }^{3}$. 
Dada la capacidad infectante de Francisella tularensis, su manipulación supone un riesgo elevado de contaminación para el personal de laboratorio, siendo hasta los años 70 la tercera causa más frecuente de accidente en el laboratorio ${ }^{59,60}$. Lo cual implica que para el aislamiento de Francisella tularensis a partir de una muestra patológica es necesario al menos un laboratorio equipado con un nivel 2 de Bioseguridad, recomendándose el uso de cabinas de seguridad biológica para su manipulación ${ }^{140}$. Una vez aislada la bacteria se recomienda su manipulación en un laboratorio de seguridad biológica de nivel $3^{3,140}$.

\section{- Identificación directa del agente}

Francisella tularensis puede ser identificada a través del examen directo de muestras de secreciones, exudados o biopsias usando las técnicas de inmunofluorescencia directa (FAT) o inmunohistoquímica ${ }^{10,12}$.

Aunque estas técnicas sean compatibles con el diagnóstico en humanos no se suelen utilizar, su uso más frecuente es para el diagnóstico de tularemia post mortem en especies animales ${ }^{141,142}$.

\section{- PCR (Polymerase Chain Reaction)}

Se utiliza para la detección del ADN de Francisella tularensis directamente a partir de las muestras (humanas, animales o ambientales) ${ }^{12}$.

Nos permite determinar la subespecie o genotipo, tanto en cepas aisladas como en muestras clínicas, aunque principalmente se suele utilizar en brotes aislados y en el diagnóstico de la forma ulceroglandular ${ }^{12}$.

Ventajas de la técnica de PCR ${ }^{3}$ :

a) Mayor rendimiento diagnóstico.

b) Diagnóstico más precoz que con las técnicas serológicas. 
c) Menor riesgo de accidentes.

d) Se puede usar mientras el paciente está con tratamiento antibiótico.

Pruebas de detección de antígenos como WB (inmunoblotting) o PFGE (Pulsedfield Gel Electrophoresis) y otras técnicas especializadas también se pueden usar para identificar Francisella tularensis y definir subespecies ${ }^{10,11}$.

\section{- Diagnóstico microbiológico indirecto $\rightarrow$ Serología}

○ Técnicas de aglutinación:

$\rightarrow$ Aglutinación en tubo

\section{$\rightarrow$ Microaglutinación (MAT)}

Consisten en la detección de anticuerpos aglutinantes frente a Francisella tularensis. Al no existir diferencias antigénicas entre las cepas de las diferentes subespecies, en todas las pruebas serológicas se utiliza para obtener el antígeno la subespecie holarctica, concretamente la cepa de la vacuna viva atenuada (LVS, NCTC 10857) ${ }^{12,15}$

Para que se pueda hablar de la confirmación del diagnóstico de tularemia a través de técnicas de aglutinación debe existir una seroconversión o un aumento de 4 veces entre el título de aglutinación entre dos muestras de suero tomadas con 7-10 días de diferencia ${ }^{37,141}$.

Normalmente títulos de aglutinación altos asociados a clínica compatible y unos antecedentes de contacto con posibles reservorios se consideran como indicativos de enfermedad con una probabilidad alta. En estos casos siempre es necesario tener en cuenta la posibilidad de otras infecciones como brucelosis, con las que algunas formas clínicas de tularemia especialmente en 
sus fases iniciales, pueden presentar sintomatología similar, además de poder presentar reacciones serológicas cruzadas ${ }^{5,143}$.

Los títulos a partir de la cual se considera que un caso de tularemia es probable varían según los autores, pero normalmente se suele tomar como referencia:

- $\quad$ Títulos de aglutinación en tubo $\geq 1: 160$ 5,10,46,141

- Títulos de microaglutinación $\geq 1: 128^{10,46}$

Niveles detectables de anticuerpos aglutinantes suelen aparecer una semana después de la infección (entre 10 y 14 días después), pero los títulos máximos que confieren especificidad al diagnóstico serológico no aparecen hasta pasadas más de 2 semanas (entre 2 y 6 semanas más tarde) ${ }^{34,37,141}$. La respuesta serológica puede ser mitigada con la administración previa de tratamiento antibiótico ${ }^{3737}$. También se ha observado que los niveles de anticuerpos aglutinantes permanecen detectables en suero varios años después de haber sido superada la enfermedad ${ }^{37}$.

La principal desventaja que ofrece esta técnica es que Francisella tularensis puede presentar reacciones cruzadas con Brucella spp, Proteus OX19 y Yersinia spp, de hecho el propio Dr. Edward Francis en sus estudios sobre aglutinación llevados a cabo en 1926 ya determinó que pacientes con brucelosis pueden tener títulos elevados frente a Francisella tularensis ${ }^{5,37}$.

\section{○ ELISA (Enzyme-Linked Inmunosorbent Assay)}

La técnica de ELISA es un inmunoensayo utilizado para detectar y cuantificar anticuerpos o antígenos. Esta técnica ofrece muchas ventajas sobre otro tipo de ensayos, incluyendo mayor facilidad de realización que otros procedimientos, una gran precisión y sensibilidad y ser fuertemente específica. Permite la detección de las diferentes clases de inmunoglobulinas frente a los 
antígenos microbianos, lo que en algunos casos permite conocer si es una infección reciente o antigua.

En el caso de Francisella, la técnica de ELISA es una técnica sensible y específica que permite realizar un diagnóstico serológico de la tularemia, pero no es útil para conocer cuándo fue el inicio de la infección dado que los niveles de inmunoglobulinas descienden lentamente. Además, un nivel alto de $\lg M$ específicas no indica necesariamente una infección reciente ${ }^{141}$.

Tabla 3: Resumen de evolución del nivel de anticuerpos en suero (Elaborado a partir de Koskela et al. ${ }^{34}$ )

\begin{tabular}{|c|c|c|c|}
\hline & 5 días & Nivel max. Ac & Disminución \\
\hline $\lg \mathbf{G}$ & $36 \%$ & $16-90$ días & Mantiene títulos $\uparrow$ \\
\hline $\lg M$ & $18 \%$ & $16-71$ días & $\downarrow$ entre $3-6$ meses \\
\hline Ig A & $9 \%$ & $16-71$ días & $\downarrow$ entre 3-6 meses \\
\hline
\end{tabular}

Como se ha mencionado anteriormente, los anticuerpos específicos aparecen entre 6 y 10 días tras los síntomas ( 2 semanas después del contagio) 3 . Los diferentes tipos de inmunoglobulinas prácticamente aparecen de manera simultánea y se mantienen detectables en suero entre 2 y 11 años ${ }^{34,144-146 .}$

\section{- Inmunocromatografía}

Una de las últimas pruebas serológicas introducidas en el diagnóstico indirecto de la tularemia son las pruebas de inmunocromatografía. Se caracteriza por ofrecer resultados en pocos minutos, aunque tiene el inconveniente de que sólo detecta anticuerpos totales frente al lipopolisacárido de Francisella tularensis y no detecta de forma individualizada los anticuerpos de cada una de las clases de inmunoglobulinas. 


\section{Tratamiento}

El género Francisella presenta una sensibilidad a los antimicrobianos muy estable y el tratamiento es altamente eficaz. Dentro de los antibióticos utilizados en el tratamiento de la tularemia existentes, los aminoglucósidos han mostrado una alta eficacia terapéutica bactericida frente a Francisella tularensis tipo A y B, así como unos mejores resultados y bajas tasas de recidiva ${ }^{11,15,147}$. Concretamente la estreptomicina ha sido considerada durante mucho tiempo como el fármaco de primera elección en pacientes graves, aunque en el momento actual viene siendo sustituido por la gentamicina ${ }^{3,15}$.

Los problemas que presentan los aminoglucósidos están relacionados con su imposibilidad para ser administrados por otra vía que no sea la parenteral, la toxicidad asociada y el hecho de que la estreptomicina no está disponible en muchos países ${ }^{11,147}$.

Tetraciclinas y fluoroquinolonas también se utilizan para el tratamiento de la tularemia en humanos aunque su uso es más frecuente en casos de enfermedad leve o moderada sobre todo en Europa, deberán administrarse durante al menos dos semanas, pero permiten su administración por vía oral facilitando el tratamiento a nivel domiciliario 3,11,15,147. Dentro de los inconvenientes de las fluoroquinolonas está la contraindicación en el embarazo ya que potencialmente pueden inducir malformaciones fetales ${ }^{11,15,147}$.

\section{Profilaxis}

Las medidas que se emplean para prevenir el contagio de tularemia en humanos son variadas y no siempre igualmente efectivas. Siendo obvio que la mejor prevención será siempre evitar la exposición a las bacterias ${ }^{3}$. 


\section{Profilaxis de exposición}

Dentro de las protecciones que se pueden llevar a cabo para evitar la exposición a Francisella tularensis se encuentran:

- Restringir el contacto con los reservorios, en función de cuales sean los animales que puedan actuar como vector de transmisión de la enfermedad en cada área endémica ${ }^{15}$.

- Evitar desollar o preparar animales salvajes sin el uso de guantes, a los que se añadirá el uso de mascarilla y protección ocular en el caso de manipulación de animales muertos de origen desconocido ${ }^{3}$.

- Cocinar adecuadamente la carne de caza antes de su consumo y evitar usar agua de pozos que puedan estar contaminados por heces 0 cadáveres de animales ${ }^{3}$.

- Respecto a las garrapatas y otros artrópodos, evitar las picaduras con el uso de ropa que cubra la mayor parte del cuerpo y sea ajustada en la zona de los puños. En el caso de garrapatas adheridas será necesario eliminarlas rápidamente evitando aplastarlas ${ }^{3}$.

- Al no existir evidencias de contagio de humano a humano, no será necesario tener medidas de aislamiento especiales con los pacientes hospitalizados ${ }^{3}$.

- Aunque haber padecido la enfermedad confiere cierto estado de inmunidad, esta es solo parcial ya que pueden existir reinfecciones ${ }^{1,11}$.

En lo que respecta a la profilaxis antibiótica decir que es útil en aquellos casos en que existe una exposición probada a Francisella tularensis, la OMS reconoce su utilidad solo en caso de exposición accidental de personal de laboratorio ${ }^{11,15}$. 


\section{Profilaxis de disposición}

Dentro de los métodos de bioprofilaxis el único que tiene relevancia es la vacuna. Se trata de una vacuna viva basada en una cepa atenuada de Francisella tularensis subsp. holarctica (LVS), puesto que la vacuna elaborada a partir de bacterias muertas es ineficaz ${ }^{3,15}$. Dentro de las propiedades de la vacuna se pueden destacar: la inducción de inmunidad humoral y celular, ser eficaz frente a la enfermedad de tipo tifoídica y reducir la gravedad de la enfermedad de tipo ulceroglandular, aunque no llega a prevenirla ${ }^{3}$.

La vacuna viva atenuada se utilizó durante décadas como vacuna de la tularemia, especialmente por el personal de laboratorio. Pero en la actualidad su uso no es muy habitual al mostrar normalmente una baja eficacia 3,15. Nuevas vacunas están siendo desarrolladas, pero todavía no están listas para ser empleadas en humanos ${ }^{3,148,149}$.

La inclusión de Francisella tularensis en la lista del gobierno estadounidense de "Biological Select Agents or Toxins" (BSATs), debido a su posible utilización como arma biológica en un ataque terrorista ha provocado que el interés por desarrollar esta vacuna haya aumentado durante los últimos años ${ }^{31,150,151 .}$

La baja dosis de bacterias necesaria para el contagio por vía respiratoria hace que los estudios que se están llevando a cabo en materia de bioseguridad y profilaxis de la tularemia no se centren exclusivamente en el desarrollo de vacunas, sino que exista interés por desarrollar técnicas diagnósticas más rápidas y completas que permitan identificar diversos agentes al mismo tiempo o modelos de actuación después de la exposición a Francisella tularensis ${ }^{152-}$ 154. 

OBJETIVOS 

Dada la capacidad infectiva de Francisella tularensis, la gravedad de algunos de los cuadros clínicos que produce, la tendencia a producir brotes epidémicos de cierta envergadura, y su posible utilización como arma biológica, hace que en los últimos años haya aumentado de forma muy importante la investigación para encontrar nuevas formas de diagnóstico más rápidas y seguras. En este contexto, y consecuencia de los brotes epidémicos de tularemia acaecidos en España, y en particular en Castilla y León, nos hemos planteado como objetivo general de esta tesis doctoral el desarrollo de una técnica de ELISA para el diagnóstico de la tularemia humana y el estudio de la utilidad de las técnicas ELISA y de quimioluminiscencia para el diagnóstico de la tularemia humana. Como objetivos específicos nos hemos planteado:

1. Obtención del antígeno lipopolisacárido de Francisella tularensis para la estandarización de técnicas de ELISA IgM e IgG que permitan el diagnóstico de la tularemia humana.

2. Conocer la utilidad de las pruebas de ELISA y quimioluminiscencia en el diagnóstico de tularemia humana a través del estudio de sensibilidad, especificidad y las razones de probabilidad positiva y negativa (likelihood ratio + y -).

3. Estudiar la utilidad de las pruebas de ELISA y quimioluminiscencia comparándolas con la técnica de referencia en el diagnóstico de la enfermedad, concretamente la microaglutinación en placa.

4. Evaluar el comportamiento de las pruebas de ELISA y quimioluminiscencia frente a una batería de 773 sueros de pacientes con diferentes formas clínicas de tularemia y con diferentes patologías que podrían dar lugar a falsos positivos en las pruebas sometidas a evaluación. 

MATERIAL Y MÉTODOS 

Dentro del apartado de material de esta tesis vamos a diferenciar por un lado el material clínico que se ha utilizado en el estudio, es decir, los diferentes sueros que se han analizado, y por otro lado los métodos empleados incluyendo los antígenos microbianos en cada una de las técnicas utilizadas, así como la estandarización y la ejecución de cada una de las técnicas.

\section{Material clínico}

El material clínico utilizado se compone de 773 sueros obtenidos de diferentes grupos de pacientes.

Dichos sueros forman parte de la colección de sueros existente en el Laboratorio Regional de Referencia en Brucelosis de la Universidad de Valladolid. Dado que el estudio se ha realizado sobre técnicas que permiten el diagnóstico de tularemia en humanos, los sueros seleccionados proceden del brote acaecido en 1997 y 1998 en la región de Castilla y León. Para garantizar la homogeneidad en el estudio el resto de los sueros correspondieron a pacientes de la misma región y fueron obtenidos en el mismo periodo de tiempo. Todas las muestras se mantuvieron congeladas a $-40^{\circ} \mathrm{C}$ hasta el momento de su utilización en el estudio.

Los 773 sueros se clasificaron en cuatro grupos en función de la patología de base que presentaran los pacientes, quedando divididos de la siguiente forma:

- Sueros de pacientes con tularemia como grupo control positivo.

- Sueros de pacientes con sospecha de tularemia no confirmada posteriormente.

- Sueros del grupo control negativo.

- Sueros de pacientes con otras enfermedades, como grupos control de especificidad:

- Sueros de pacientes con brucelosis.

- Sueros de pacientes con otras infecciones.

- Sueros de pacientes con enfermedades autoinmunes. 


\subsection{Sueros de pacientes con tularemia}

Para definir el diagnóstico clínico de tularemia se emplearon los criterios establecidos por el Centro para el Control y Prevención de Enfermedades del Departamento de Salud y Servicios Humanos de los Estados Unidos (CDC) mencionados anteriormente ${ }^{135}$.

Este primer grupo está formado por 364 muestras de suero procedentes de 364 pacientes en los que la tularemia fue diagnosticada y confirmada durante el brote ocurrido en Castilla y León (concretamente en las provincias de Palencia, Valladolid y Zamora) durante los años 1997 y 1998.

En todos los casos estos sueros fueron obtenidos en el momento en que los pacientes acudieron para una primera consulta, en la cual ya existía una sospecha de la enfermedad que posteriormente sería confirmada por los métodos diagnósticos anteriormente mencionados. Concretamente, en 7 de los casos se aisló Francisella tularensis (en dos muestras de exudado de úlceras y en cinco hemocultivos), y el resto de los casos se confirmaron mediante técnicas indirectas de microaglutinación, bien sea a través de seroconversión en los casos que fueron negativos en el primer análisis, o mediante un aumento de al menos 4 veces en el título de microaglutinación frente a Francisella tularensis en un nuevo suero extraído del paciente al menos 7 días más tarde de la primera extracción.

\subsection{Sueros de pacientes con sospecha de tularemia no confirmada}

Para conformar el segundo grupo de estudio se han seleccionado 100 sueros de pacientes que, a pesar de acudir a la consulta con clínica sospechosa de tularemia, la enfermedad no fue confirmada posteriormente. Para aportar solidez al estudio dichos sueros fueron obtenidos de las mismas áreas del brote epidémico de tularemia y durante el mismo período de tiempo en el que se desarrolló dicho brote.

Los criterios establecidos que nos permiten considerar a un paciente como sospechoso de padecer tularemia son: que el cuadro clínico que presenta sea compatible con cualquiera de las formas clínicas en que se 
desarrolla la enfermedad, y un antecedente epidemiológico, esto es, procedentes de una de las áreas con brote epidémico de tularemia por residir en ella o por haber viajado a estas zonas en época epidémica.

\subsection{Sueros del grupo control negativo}

Para poder calcular la especificidad de las pruebas diagnósticas utilizamos un tercer grupo de sueros de personas sanas que nos sirviera de control negativo. Para ello se han seleccionado aleatoriamente las muestras de suero de 152 sujetos sanos procedentes de un conjunto de 4825 sueros obtenidos para la realización de un estudio seroepidemiológico sobre diferentes zoonosis llevado a cabo en la comunidad autónoma de Castilla y León entre los meses de abril de 1996 y abril de 1997. Las muestras de suero se tomaron en centros públicos de extracción de sangre de la Red de Atención Primaria y fueron estratificadas por provincias y área de salud ${ }^{122,155,156 .}$

Todos los sueros utilizados en el estudio procedían de personas sanas, sin ninguna sintomatología ni sospecha de enfermedad infecciosa, incluida infección por Francisella tularensis. Además, los sueros utilizados procedían de personas que vivían en las mismas áreas donde se produjeron los brotes de tularemia de los años 1997 y 1998.

\subsection{Sueros de pacientes con otras enfermedades}

El cuarto grupo de estudio está formado por pacientes con un diagnóstico confirmado de enfermedades diferentes a la tularemia, permitiéndonos estudiar las posibles reacciones cruzadas o falsos positivos que pudieran aparecer con las técnicas utilizadas.

Para estudiar estas posibles reacciones cruzadas se han seleccionado:

- Sueros de pacientes afectados por brucelosis.

- Sueros de sujetos que padecían otras infecciones.

- Sueros de pacientes con enfermedades autoinmunes. 


\section{a) Sueros de pacientes con brucelosis}

Se seleccionaron 97 sueros de pacientes con brucelosis confirmada; de los que 66 sueros corresponden a procesos de brucelosis aguda, 4 sueros de pacientes que presentaron una recurrencia de la enfermedad después de haber sido tratada anteriormente y 27 sueros pertenecen a pacientes que contrajeron la brucelosis en los 24 meses anteriores a la obtención del suero pero que en el momento de la misma se encontraban totalmente curados de la enfermedad.

Los criterios utilizados para la selección de los pacientes con brucelosis son los recogidos por el CDC y la OMS 157,158. Según estos organismos, la brucelosis se define como: "enfermedad infecciosa producida por bacterias de la familia Brucella spp. y caracterizada por la aparición de manera aguda o insidiosa de fiebre y una o más de las siguientes manifestaciones: sudores nocturnos, cansancio, anorexia, mialgia, pérdida de peso, cefalea, dolor de articulaciones, artritis/espondilitis, meningitis, o afectación de órganos focales (endocarditis, orquitis/epididimitis, hepatomegalia, esplenomegalia)".

Desde la última actualización realizada en el año 2010 por el CDC, los criterios de laboratorio que deben cumplirse para su diagnóstico son ${ }^{158}$ :

- Criterios de sospecha: títulos de anticuerpos de Brucella total $\geq 160$ realizando la prueba de seroaglutinación en tubo (SAT) o microaglutinación en placa (BMAT) en uno o más sueros obtenidos después del comienzo de los síntomas.

También se pueden considerar como caso probable de brucelosis aquellas muestras en las que se produzca detección de ADN de Brucella spp. mediante PCR.

- Criterios definitivos: a través del cultivo e identificación de Brucella spp. en muestra clínica; o mediante pruebas indirectas, demostrando evidencia de un aumento de al menos 4 veces el título de anticuerpos de Brucella en los sueros obtenidos entre la fase aguda de la enfermedad y la fase de convalecencia (con dos o más semanas de separación entre ambos). 
Siguiendo estos criterios se llegará a la confirmación del caso, siempre y cuando el paciente tenga una clínica compatible con la enfermedad y existan pruebas de laboratorio definitivas que confirmen la infección por Brucella.

Todos los sueros incluidos en nuestro estudio cumplían los criterios de confirmación de sufrir una brucelosis o de haberla sufrido con anterioridad.

Aunque no se han incluido en nuestro trabajo, el CDC define como caso clínico probable cuando sean compatibles con al menos uno de los siguientes criterios:

- Asociación epidemiológica con casos humanos confirmados o de brucelosis animal.

- Sospecha de evidencias de laboratorio, pero sin una confirmación definitiva de infección por Brucella.

\section{b) Sueros de pacientes con enfermedades autoinmunes}

En lo que respecta al grupo de pacientes con enfermedades autoinmunes se han estudiado: artritis reumatoide (7 sueros), lupus eritematoso sistémico (6 sueros), hepatitis autoinmune ( 3 sueros), cirrosis biliar primaria ( 3 sueros), gastritis atrófica (4 sueros), síndrome de Sjögren (4 sueros), esclerodermia (2 sueros), vasculitis asociada a ANCA (anticuerpos anticitoplasma de neutrófilos) (1 suero).

\section{c) Sueros de pacientes con otras infecciones}

También se estudiaron 30 sueros de pacientes con otras infecciones confirmadas, de los cuales 6 sueros son de paciente con gastroenteritis por Salmonella spp., 2 sueros de pacientes con fiebre tifoidea, 7 sueros de paciente con Helicobacter pylori y 15 sueros de pacientes con toxoplasmosis. 


\section{Métodos}

\subsection{Obtención de los antígenos microbianos}

Los antígenos utilizados en las diferentes pruebas fueron:

- Antígeno corpuscular: utilizado en la técnica de microaglutinación y como base para la obtención de antígeno lipopolisacárido.

- Antígeno lipopolisacárido: utilizado en las pruebas de enzimoinmunoensayo y en las de quimioluminiscencia.

Salvo en el caso de la técnica de quimioluminiscencia, el resto de las pruebas fueron realizadas en el laboratorio, obteniendo y purificando los antígenos de Francisella tularensis en el mismo laboratorio. La prueba serológica de quimioluminiscencia era comercial ("Tularemia VirClia® IgG+lgM monotest"; Vircell, Santa Fe, Granada, España), utilizando para su desarrollo antígeno LPS producido en nuestro laboratorio.

Para la ejecución de la prueba, en todo momento se siguieron las indicaciones del fabricante para la correcta utilización de las pruebas de quimioluminiscencia.

\section{a) Preparación de la suspensión madre de Francisella tularensis}

Todo el antígeno utilizado en las diferentes pruebas se obtuvo a partir de una suspensión madre de Francisella tularensis subsp. holarctica LVS.

La suspensión madre se obtuvo a partir del cultivo de las bacterias en medio líquido Müeller-Hinton suplementado con cisteína (Merck, Darmstand, Alemania), concretamente $1 \mathrm{gr} / \mathrm{l}$, y un vial de Isovitalex (Difco laboratories, Detroit, Michigan, USA). La cepa empleada fue Francisella tularensis subsp. holarctica LVS, ref. NCTC 10857. Todo el procedimiento de inoculación y cultivo se realizó en campana de flujo laminar dentro del laboratorio de 
seguridad biológica nivel 3. Se incubaron 10 matraces de 5 litros durante tres días a $37^{\circ} \mathrm{C}$ con un $10 \%$ de $\mathrm{CO} 2$ y con agitación constante (200 r.p.m.) en incubador agitador orbital.

La pureza del cultivo se comprobó mediante resiembra en placas de agar chocolate con polivitex (BioMerieux, Marcy l'Etoile, Francia) que se incubaron durante 4 días a $37^{\circ} \mathrm{C}$ con un $10 \%$ de $\mathrm{CO}_{2}$.

Tras conocer la pureza de nuestro cultivo, se llevó a cabo la muerte de las bacterias de Francisella tularensis. La suspensión madre de Francisella tularensis se dividió en dos partes. La parte utilizada para la producción de antígeno corpuscular fue tratada con formol al 0,5\% (concentración final) e incubada durante 3 días a $37^{\circ} \mathrm{C}$.

La parte utilizada para la obtención del lipopolisacárido se trató con fenol al $0,5 \%$ durante 2 días a $37^{\circ} \mathrm{C}$.

En ambos casos, posteriormente realizamos un control de su esterilidad (resiembra en placas de agar chocolate con polivitex e incubación durante 3 días a $37^{\circ} \mathrm{C}$ con un $10 \%$ de $\mathrm{CO}_{2}$ ), comprobando la ausencia de crecimiento.

Una vez asegurada la esterilidad se centrifugó la solución madre de Francisella tularensis a 8000 r.p.m. a una temperatura de $4^{\circ} \mathrm{C}$ durante 10 minutos. Tras eliminar el medio de cultivo sobrenadante y realizar 3 lavados con solución salina fisiológica en las mismas condiciones, se recogió el sedimento de Francisella tularensis.

\section{b) Preparación y estandarización del antígeno corpuscular para microaglutinación}

Para llevar a cabo la microaglutinación en placa se procedió a resuspender una parte del sedimento en $100 \mathrm{ml}$ de solución salina fisiológica con formol al 0,5\% hasta ajustar la densidad celular de la preparación al número 4 en la escala de McFarland, siguiendo la técnica de Brown et al. que nos permite la estandarización del proceso ${ }^{159,160}$. 
Una vez resuspendido el antígeno se centrifugó a 9000 r.p.m. durante 10 minutos $y$, tras eliminar el sobrenadante, lo resuspendimos en solución salina fisiológica con formol al $0,5 \%$ y safranina-O al $0,005 \%$ hasta volver a obtener el volumen original. El antígeno corpuscular ya teñido se almacenó en frascos opacos a $4^{\circ} \mathrm{C}$.

Finalmente, para comprobar que la estandarización que se ha realizado del proceso es la adecuada, el antígeno fue ensayado con un panel de 20 sueros control positivo procedentes de pacientes con tularemia y 20 sueros control negativo.

\section{c) Obtención del antígeno lipopolisacárido}

En el caso de las técnicas de ELISA y quimioluminiscencia se utilizó como antígeno el LPS. Para su obtención se partió de la suspensión madre de Francisella tularensis muerta con fenol. Seguimos el método del fenol caliente descrito por Westphal y Jann para enterobacterias ${ }^{161,162}$, modificado por Sandström et al. para Francisella tularensis ${ }^{163}$.

Una vez muertas las bacterias mediante tratamiento con $0,5 \%$ de fenol, se procedió a realizar 3 ciclos de lavado con agua destilada, centrifugándolo a 9000 r.p.m. a una temperatura de $4^{\circ} \mathrm{C}$ durante 15 minutos y eliminando el sobrenadante.

El sedimento obtenido de los lavados se resuspendió en agua destilada con una proporción aproximada de $5 \mathrm{gr}$ de bacterias por cada $200 \mathrm{ml}$ de agua destilada. El matraz con la suspensión se introdujo en un baño maría a $66^{\circ} \mathrm{C}$ y se añadió un volumen igual de fenol al 100\% fundido en el baño maría también a $66^{\circ} \mathrm{C}$. La suspensión resultante fue sometida a agitación violenta con agitador de hélice durante 15 minutos. Todo este proceso se realizó dentro del baño maría a temperatura constante de $66^{\circ} \mathrm{C}$.

La suspensión de bacterias y fenol del baño maría fue enfriada por inmersión de los matraces en hielo picado. Una vez fría se procedió a 
centrifugarla a 13000 r.p.m. durante 30 minutos a $4^{\circ} \mathrm{C}$. Tras la centrifugación se extrajeron la fase acuosa, la interfase y la fase fenólica resultantes, y cada tipo de fracción se volvió a centrifugar a 13000 r.p.m. durante 30 minutos a 4º $\mathrm{C}$ para recuperar el máximo de la fase acuosa. La fase acuosa se filtró para eliminar los restos celulares con papel de filtro. Posteriormente se procedió a la precipitación durante 24 horas con 4 volúmenes de metanol frio $\left(-20^{\circ} \mathrm{C}\right)$. EI LPS crudo se obtuvo del precipitado por centrifugación a 13.000 r.p.m. durante 30 minutos a $4^{\circ} \mathrm{C}$. El precipitado fue disuelto en agua destilada y posteriormente se dializó con 5 litros de agua destilada durante 5 días a $4^{\circ} \mathrm{C}$, con 4 cambios de agua destilada.

EI LPS purificado fue obtenido a partir del LPS crudo, tratándolo 3 veces con $0,1 \mathrm{mg} \mathrm{ml}^{-1}$ de RNasa A (Sigma-Aldrich) y $0,1 \mathrm{mg} \mathrm{ml}^{-1}$ de DNasa II type $\mathrm{V}$ (Sigma-Aldrich) a $37^{\circ} \mathrm{C}$ durante 30 minutos, y posteriormente 3 veces con $1 \mathrm{mg}$ $\mathrm{ml}^{-1}$ de Proteinasa K (Sigma-Aldrich) a 55드 durante 3 horas. El LPS purificado se obtuvo por centrifugación (100 000 r.p.m. durante 6 horas) y después de un nuevo dializado, finalmente procedimos a su liofilización.

\subsection{Pruebas serológicas utilizadas}

\section{a) Prueba de microaglutinación en placa}

- Material de la técnica de microaglutinación:

1) Solución salina fisiológica al $0,9 \%$ (SSF).

2) Antígeno: antígeno corpuscular de Francisella tularensis teñido con safranina.

3) Soporte de la reacción: placas de microtitulación con 96 pocillos de fondo en U estériles (Greiner, Kremsmünster, Austria).

4) Sueros de pacientes a estudio. 
- Realización de la técnica:

Se dispensaron $45 \mu \mathrm{l}$ de SSF en el primer pocillo de la placa y $25 \mu \mathrm{l}$ en el resto de los pocillos, a continuación se añadieron $5 \mu \mathrm{l}$ de suero problema $o$ control en el primer pocillo mezclándolo con la SSF obteniendo una dilución del suero $1 / 10$. Se tomaron $25 \mu \mathrm{l}$ de dicho pocillo y a continuación se introdujeron en el siguiente pocillo (dilución 1/20). Se repitió el proceso hasta completar 10 diluciones, del último pocillo se tomaron $25 \mu$ que se desecharon. Se añadieron $25 \mu \mathrm{l}$ de la solución de antígeno teñido con safranina en cada pocillo, con lo que la primera dilución pasa a ser de 1/20, duplicándose exponencialmente la dilución según se avanza hasta llegar a 1/10 240 en el décimo pocillo. El último pocillo de cada fila (pocillo 12) se utilizó como control de antígeno (conteniendo $25 \mu \mathrm{l}$ de SSF y $25 \mu \mathrm{l}$ de antígeno). Se taparon las placas y se agitaron 20 segundos en agitador. Se incubaron 24 horas a $37^{\circ} \mathrm{C}$, tras lo cual se hizo la lectura de la reacción.

Clasificamos como positivos aquellos pocillos en los que se encontró una malla de más del $50 \%$ de la superficie del pocillo. Siendo considerado como negativo cuando no se cumplía este criterio.

\section{b) Prueba de ELISA frente a lipopolisacárido de Francisella tularensis (ELISA IgG Y ELISA lgM)}

\section{- Material de la técnica de ELISA:}

1) Antígeno: se utilizó el lipopolisacárido purificado (LPS) de Francisella tularensis conservado liofilizado a temperatura ambiente.

2) Soporte de la reacción: microplacas de poliestireno de 96 pocillos con fondo plano (Bioreba F ELISA).

3) Tampón carbonato-bicarbonato $(\mathrm{pH} \mathrm{9,6).}$ 
4) PBS (tampón fosfato salino): por cada tableta de PBS (Oxoid, Basingstoke, Reino Unido) se añadieron $100 \mathrm{ml}$ de agua destilada, disolviéndose mediante agitación a temperatura ambiente. Se conservó en frigorífico a una temperatura entre 2 y $8^{\circ} \mathrm{C}$.

5) PBS-Tween 20: se preparó diluyendo al 0,05\% el Tween 20 (Merck, Darmstand, Alemania) en PBS mediante agitación. Se conservó a una temperatura entre 2 y $8^{\circ} \mathrm{C}$ hasta su uso. Su preparación se realizó diariamente.

6) PBS-T-BSA: se preparó una solución de Tween 20 al 0,05\% en PBS y se añadió fracción $V$ de seroalbúmina bovina (BSA) (Sigma, Taufkirchen, Alemania) hasta una concentración del 1\%. Esta solución se disolvió mediante agitación a temperatura ambiente y se preparó diariamente.

7) Conjugado anti-lgG humana: contiene inmunoglobulinas de conejo antiIgG humana (cadena gamma) conjugadas con peroxidasa de rábano picante (Sigma, Taufkirchen, Alemania).

8) Conjugado anti-IgM humana: inmunoglobulinas de conejo anti-lgM humana (cadena mu) conjugadas con peroxidasa de rábano picante (Sigma, Taufkirchen, Alemania).

Las diluciones de trabajo de cada conjugado se hicieron en PBS-T-BSA inmediatamente antes de su utilización.

9) Solución de substrato: tetrametil-bencidina (TMB) ELISA substrato (BioRad, Hercules, CA, EE. UU.).

10) Solución de parada: ácido sulfúrico $2,5 \mathrm{~N}$.

11) Controles positivos y negativos y sueros de pacientes a estudio.

- Estandarización de la técnica:

Para la estandarización del revestimiento se utilizaron diferentes concentraciones de LPS (desde $50 \mu \mathrm{g} / \mathrm{ml}$ hasta $1,5 \mu \mathrm{g} / \mathrm{ml}$ ) diluido en tampón carbonato-bicarbonato $(\mathrm{pH} 9,6)$ y se incubaron a $37^{\circ} \mathrm{C}$ durante 1 hora. La estandarización de la prueba se llevó a cabo utilizando un panel de sueros control constituido por: 
- Sueros control positivo fuerte: 10 sueros de pacientes diagnosticados de tularemia con títulos de anticuerpos elevados, detectados mediante prueba comercial de aglutinación en tubo (Difco). Los sueros presentaban un título $\geq 1 / 640$.

- Sueros control positivo medio: 10 sueros de pacientes diagnosticados de tularemia con unos títulos de seroaglutinación entre $1 / 160$ y $1 / 640$.

- Sueros control negativo: 25 sueros de donantes sanos con resultados negativos en las pruebas de seroaglutinación frente a Francisella tularensis y sin antecedentes de tularemia.

Para llevar a cabo el revestimiento de las placas dispensamos $100 \mu \mathrm{lde}$ la solución madre a la concentración indicada en cada pocillo e incubamos durante 1 hora a $37^{\circ} \mathrm{C}$. Con el antígeno ya fijado se lavaron las placas cuatro veces con PBS Tween 20, para seguidamente bloquearlas con $100 \mu$ de PBST-BSA durante 1 hora a temperatura ambiente. A continuación, se realizó un nuevo ciclo de cuatro lavados con PBS-Tween 20.

\section{- Realización de la técnica:}

Una vez estandarizadas las condiciones necesarias para el revestimiento de las placas, procedimos a realizar las técnicas de ELISA siguiendo los procedimientos descritos por Porsch-Özcürümez et al. ${ }^{164}$, con ligeras modificaciones.

A cada pocillo se añadieron $100 \mu$ de suero diluido 1/200 en PBS-T-BSA y se incubaron durante 1 hora a $37^{\circ} \mathrm{C}$. Transcurrida la incubación las placas se volvieron a lavar con cuatro ciclos de PBS-Tween 20.

Se prepararon los conjugados anti-lgG y anti-lgM humanas según las instrucciones, se añadieron a razón de $100 \mu$ por pocillo y se incubaron durante una hora a $37^{\circ} \mathrm{C}$. Terminamos esta fase del proceso lavando nuevamente con cuatro ciclos de PBS-Tween 20. 
Para revelar se añadieron $50 \mu \mathrm{l}$ de TMB a cada pocillo y las placas se incubaron durante 10 minutos a temperatura ambiente en oscuridad. Posteriormente se detuvo la reacción con $50 \mu \mathrm{l}$ de ácido sulfúrico 2,5N. Para finalizar, las absorbancias de las placas se leyeron en un espectrofotómetro a una longitud de onda de $405 \mathrm{~nm}$.

Las condiciones de concentración de antígeno LPS que se utilizaron para revestir las placas en los ensayos definitivos fueron aquellas que mayor discriminación producían entre los sueros control positivo y negativo en la estandarización. Esta discriminación se obtuvo con concentraciones de 12,5 $\mu \mathrm{g} / \mathrm{ml}$ para la prueba de ELISA IgG y $25 \mu \mathrm{g} / \mathrm{ml}$ para la prueba de ELISA IgM.

Una vez conocida la concentración óptima para la realización de las pruebas, se revistieron las placas con $12,5 \mu / \mathrm{ml}$ de LPS para las pruebas de ELISA IgG y de $25 \mu \mathrm{g} / \mathrm{ml}$ para la prueba de ELISA IgM.

Para establecer el umbral de positividad de la prueba se utilizaron en cada placa los resultados del grupo de 10 sueros control negativo incluidos en cada una de las placas, tomándose como referencia la media más tres desviaciones (media $+3 \mathrm{ds}$ ) de los valores de absorbancia obtenidos. Concretamente en nuestro caso el valor umbral de positividad fue de 0,3516 para ELISA IgG y 0,3380 para ELISA IgM.

\section{c) Prueba de quimioluminiscencia frente a lipopolisacárido de $F$. tularensis (Tularemia Virclia ${ }^{\circledR} \lg G+\lg M$ monotest)}

La quimioluminiscencia (CHT) es un tipo de luminiscencia (emisión de luz visible generada cuando un electrón pasa de estado excitado a su estado habitual, sin necesidad de un aumento de temperatura), concretamente aquella en la que la emisión de luz se debe a una reacción química ${ }^{165,166}$. Dicha reacción no usa ninguna fuente de luz y puede ser medida con un luminómetro 167. 


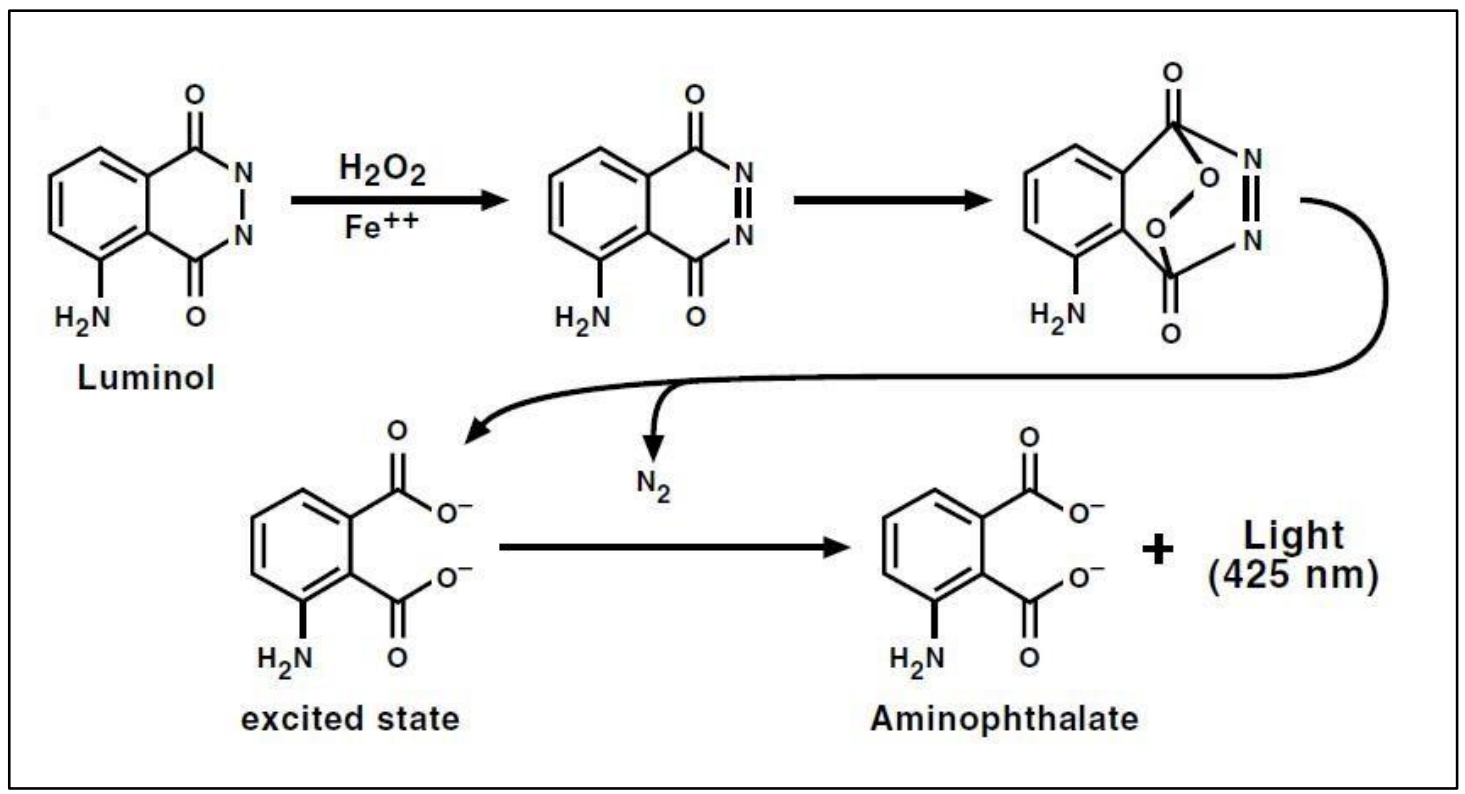

Figura 8: Oxidación del luminol para la emisión de luz (Imagen tomada de Vircell S.L.)

Durante los últimos años se ha popularizado el uso de esta técnica debido principalmente a la alta sensibilidad que presenta y a la sencillez del equipamiento necesario para su uso 167-169. Para nuestro estudio hemos utilizado el equipo de "Tularemia Virclia ${ }^{\circledR} \lg G+\lg M$ monotest" (Vircell S.L., Santa Fe, Granada).

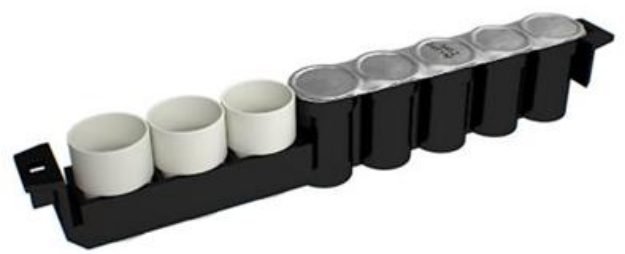

Figura 9: Virclia ${ }^{\circledR} \operatorname{lgG}+\lg M$ monotest (Imagen tomada de Vircell S.L.)

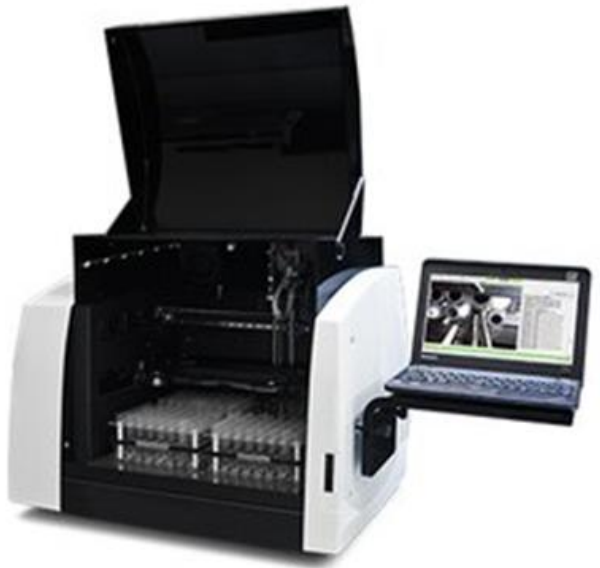

Figura 10: Virclia ${ }^{\circledR}$ System (Imagen tomada de Vircell S.L.) 
Dicho sistema funciona mediante el método de quimioluminiscencia indirecta con la peroxidasa como marcador, el luminol como sustrato e iones de hierro como potenciadores de la reacción.

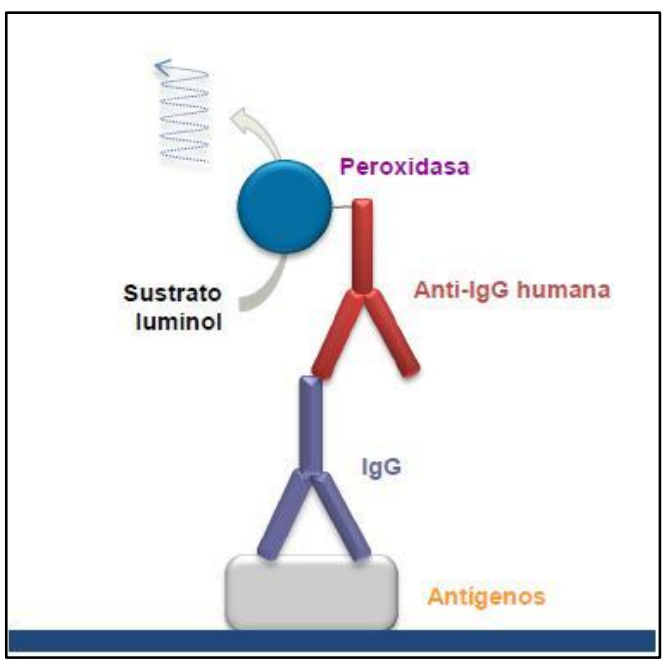

Figura 11: Modelo ensayo IgG (Imagen tomada de Vircell S.L.)

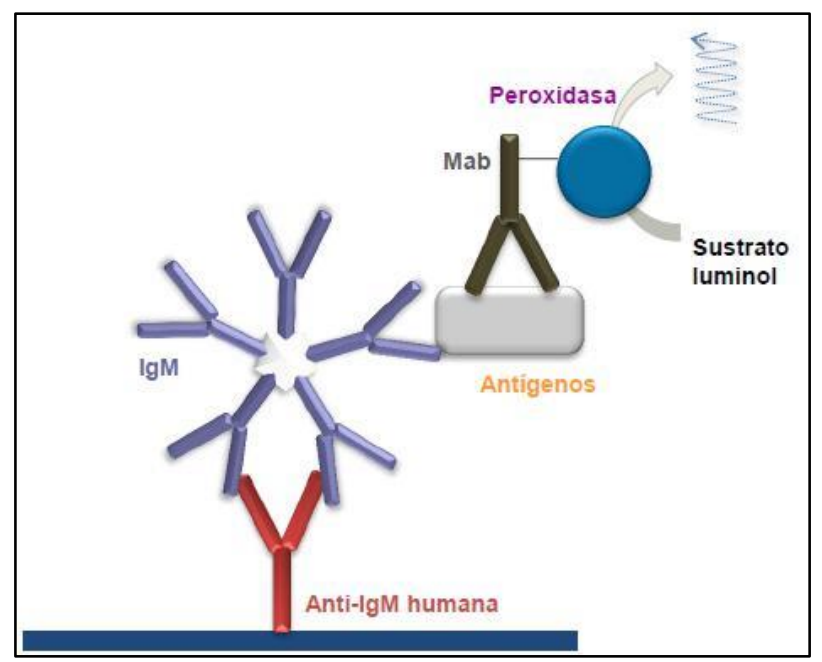

Figura 12: Modelo ensayo IgM (Imagen tomada de Vircell S.L.)

- Material de la técnica de quimioluminiscencia:

1) Tularemia Virclia® IgG+lgM monotest (Vircell S.L., Santa Fe, Granada)

Adicionalmente se requiere de un equipo Vircliaß System (Vircell S.L., Santa Fe, Granada) para la lectura e interpretación de la prueba.

- Realización de la técnica:

La técnica de quimioluminiscencia es automática y la lectura, validación e interpretación de los resultados se establece en cada muestra de manera individual siguiendo las instrucciones del equipo. El equipo establece un valor de RLU individualizado para cada muestra, que en comparación con los valores del calibrador y control negativo ofrece el resultado final de positivo, negativo 0 
dudoso. El resultado es positivo cuando los valores de Index son superiores a 1000 , estableciéndose una zona gris de $\pm 10 \%$ para aquellos resultados que son dudosos.

\subsection{Análisis estadístico}

- Los datos se analizaron con la ayuda de los programas SPSS 24 y EPIDAT 3.1.

- Se estudió la utilidad diagnóstica de las pruebas de microaglutinación en placa, ELISA IgG, ELISA IgM y "Tularemia Virclia® IgG+lgM monotest" en los 773 sueros estudiados. Se calculó la sensibilidad, la especificidad el valor predictivo y el likelihood ratio (LR) para los resultados positivos y negativos en cada estudio. Todas estas pruebas se calcularon con intervalos de confianza al 95\%.

- Los resultados de sensibilidad y especificidad obtenidos para los diferentes puntos de corte con "Tularemia Virclia ${ }^{\circledR} \lg G+\lg M$ monotest", microaglutinación en placa, ELISA IgG y ELISA IgM se representaron gráficamente mediante una Curva de Rendimiento Diagnóstico (CRD, Receive Characteristic Curve o Curva (OR) calculándose además el área bajo la curva con su correspondiente intervalo de confianza.

- El likelihood ratio (LR) del resultado positivo es la razón entre la probabilidad de observar un resultado positivo en los pacientes con la enfermedad frente a la probabilidad de ese resultado en pacientes sin la enfermedad, o lo que es lo mismo la tasa de verdaderos positivos (Sensibilidad) entre la tasa de falsos positivos (1-Especificidad) para conocer el likelihood ratio positivo, y la tasa de falsos negativos (1Sensibilidad) entre la tasa de verdaderos negativos (Especificidad) para el likelihood ratio negativo. Valores de LR positivos por encima de 10 se 
consideran altamente relevantes. El likelihood ratio del resultado negativo es similar solo que compara resultados negativos en pacientes sin la enfermedad frente a pacientes con la enfermedad. Valores de LR negativos por debajo de 0,1 se consideran altamente relevantes.

- Finalmente se comprobó la concordancia entre pruebas mediante el índice Kappa de Cohen, un instrumento creado para ajustar el efecto del azar en la proporción de la concordancia observada en variables categóricas. Esto se obtiene al enfrentar la proporción de concordancia observada a la proporción de concordancia esperada por azar. Los resultados obtenidos se interpretarán como una ínfima concordancia para valores entre 0 y 0,20, escasa concordancia para valores entre 0,20 y 0,40 , moderada concordancia para valores entre 0,40 y 0,60 , buena concordancia para valores entre 0,60 y 0,80 , y muy buena concordancia para valores entre 0,80 y 1,00 . 

RESULTADOS 



\section{Estudio descriptivo}

Se ha analizado un total de 773 sueros, de los cuales 364 sueros pertenecen a pacientes diagnosticados de tularemia, 152 sueros son de personas sanas procedentes de las áreas afectadas de tularemia y constituyen el grupo control negativo, 100 sueros son de pacientes con sospecha de tularemia en los que no se confirmó el diagnóstico de la enfermedad. Un cuarto grupo corresponde a pacientes con diagnóstico de otras enfermedades que se han utilizado para estudiar las reacciones cruzadas de las pruebas serológicas frente a Francisella con otros procesos patológicos, concretamente se trata de 97 sueros de pacientes con diagnóstico de brucelosis aguda, 30 sueros de pacientes con diagnóstico de otras enfermedades infecciosas (gastroenteritis por Salmonella spp., fiebre tifoidea, Helicobacter pylori y toxoplasmosis) y 30 sueros de pacientes con diagnóstico de enfermedades autoinmunes (artritis reumatoide, lupus eritematoso diseminado, hepatitis autoinmune, cirrosis biliar primaria, gastritis atrófica, síndrome de Sjögren, esclerodermia y vasculitis asociada a ANCA) (tabla 4).

Tabla 4: Distribución de los 773 pacientes incluidos en el estudio

Pacientes con tularemia

\begin{tabular}{|l|l|} 
Tularemia glandular & 47 \\
Tularemia neumónica & 28 \\
Tularemia oculoglandular & 5 \\
Tularemia orofaríngea & 12 \\
Tularemia tifoídica & 211 \\
Tularemia ulceroglandular & 55 \\
Forma clínica no especificada & 6
\end{tabular}

Pacientes con sospecha de tularemia no confirmada 
Pacientes con otras infecciones

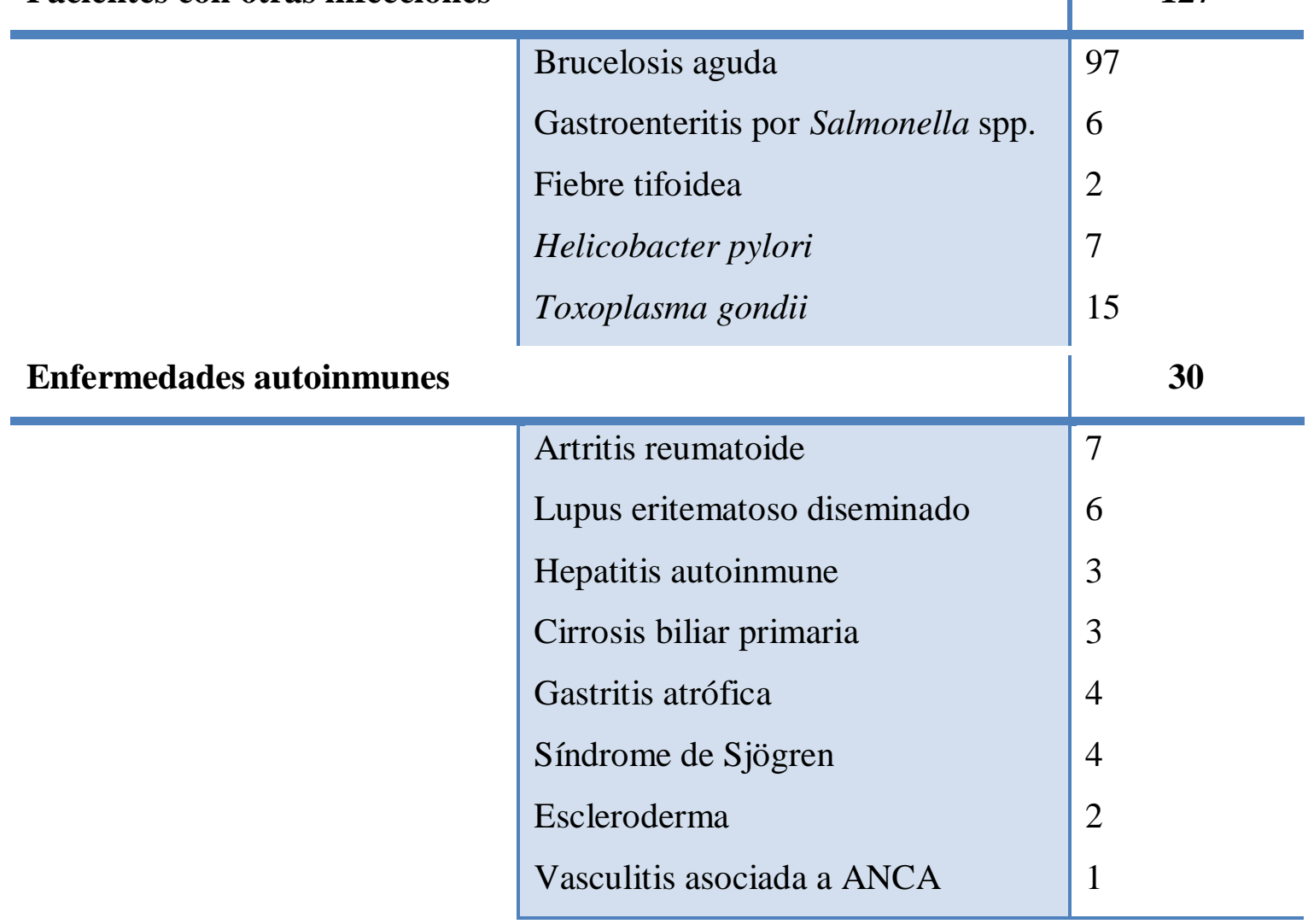

De los 364 pacientes con tularemia, $76(20,8 \%)$ fueron mujeres y 288 $(79,2 \%)$ fueron hombres, con un rango de edad comprendido entre 7 y 80 años, y una edad media de 52,9 \pm 14,5 años en el caso de las mujeres y de 51,9 \pm 15,6 años en los hombres (figura 13).

Los sujetos pertenecientes al grupo control negativo (152 sueros) presentaron una edad media fue de 50,0 $\pm 14,0$ años, 49,0 $\pm 14,3$ años en los hombres y 52,0 $\pm 13,0$ años en las mujeres; datos similares a los de los pacientes con tularemia. 


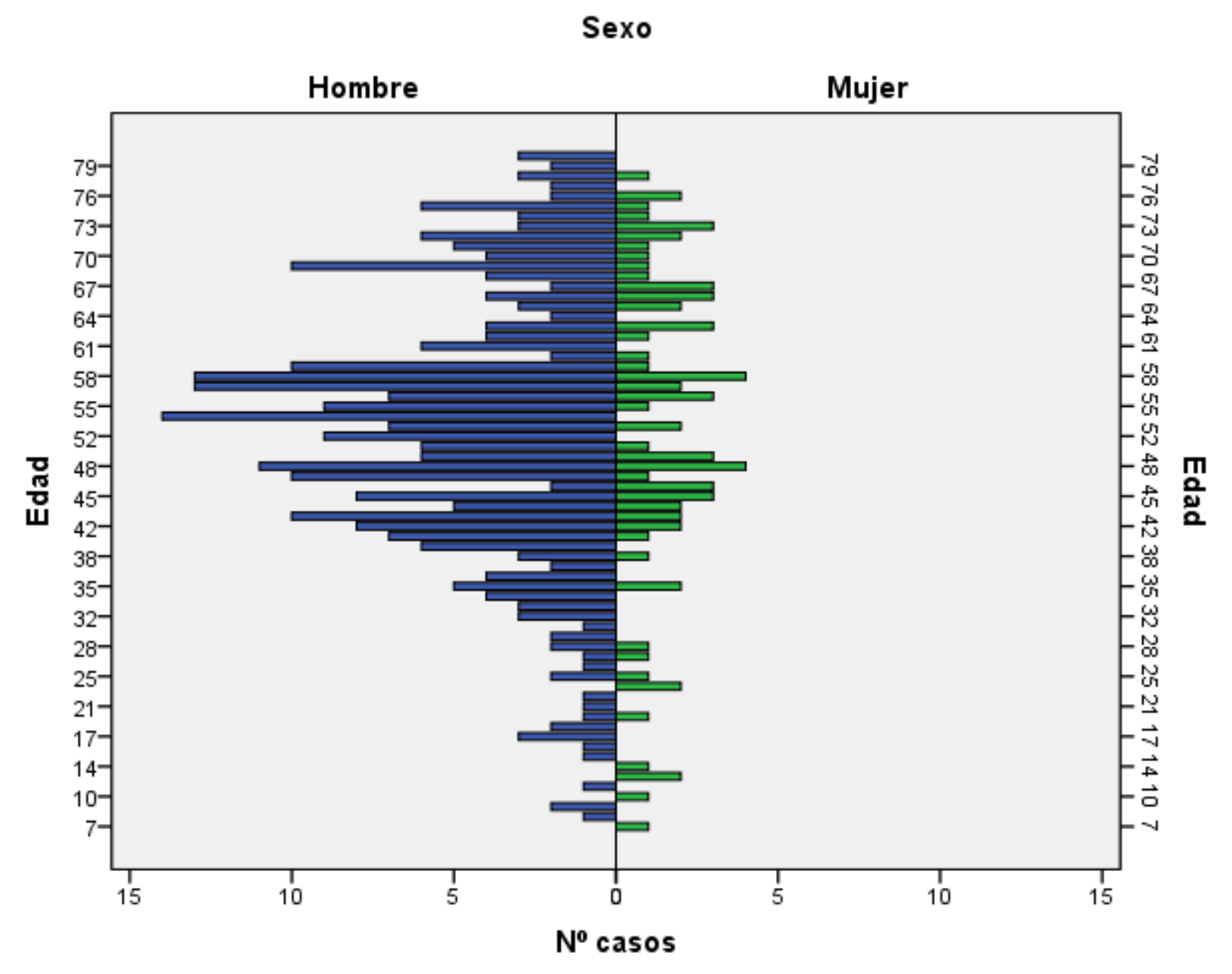

Figura 13: Número de casos de tularemia en función del sexo y la edad

En ambos grupos el grueso de los casos diagnosticados se concentra a partir de los 40 años. En el caso de los hombres, la gráfica adquiere un carácter regresivo a partir de la edad de jubilación relacionándolo directamente con las características de contagio de la enfermedad (con la excepción del número de casos en sujetos de 70 años), mientras que, en caso de las mujeres, el número de casos no marca un patrón definido pues en general se vieron afectadas amas de casa de cualquier edad.

De los 364 pacientes con tularemia, 211 casos (57,96\%) presentaron tularemia tifoídica, siendo ésta la forma clínica más frecuente, seguida por las formas ulceroglandular con 55 casos (15,10\%), glandular (47 casos, 12,91\%) y neumónica (28 casos, 7,7\%). 
Viendo la distribución de las formas clínicas por sexo (figura 14), observamos que la forma clínica tifoídica es también la más frecuente en ambos sexos con 168 casos (58,33\%) en los hombres y 43 casos (56,58\%) en las mujeres. Los casos de tularemia oculoglandular solamente tuvieron lugar entre sujetos de la población masculina; el resto de las formas clínicas se distribuyeron de forma similar entre ambos grupos.

\section{Distribución en hombres}

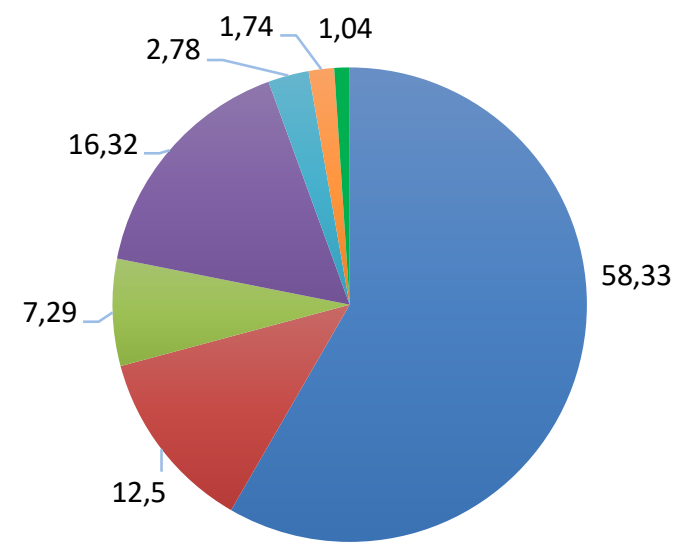

$\begin{array}{ll}\square \text { Tifoídica } & \text { Ganglionar } \quad \text { Neumónica } \quad \text { Ulceroganglionar } \\ \text { Orofaríngea } \quad \text { Oculoganglionar } \quad \text { No especificada }\end{array}$

\section{Distribución en mujeres}

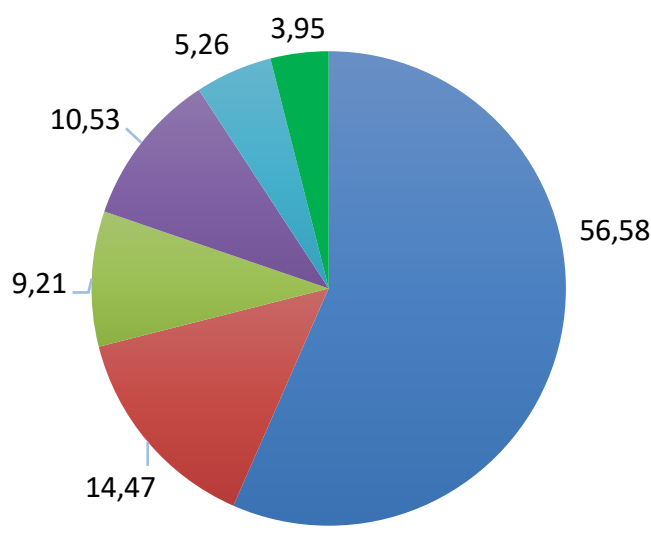

$\begin{array}{ll}\text { - Tifoídica } & \text { Ganglionar } \quad \text { Neumónica } \quad \text { Ulceroganglionar } \\ \text { Orofaríngea } & \text { Oculoganglionar } \quad \text { No especificada }\end{array}$




\section{Utilidad de las pruebas serológicas}

De los 364 sueros iniciales de pacientes con tularemia, 319 sueros $(87,7 \%)$ mostraron resultados positivos en todas las pruebas a las que fueron sometidos, 18 sueros $(4,9 \%)$ fueron negativos en todas las pruebas y 45 $(12,4 \%)$ mostraron resultados negativos en uno o más estudios. Analizando de forma individual cada prueba, la quimioluminiscencia resultó ser el único test positivo en 2 casos, la microaglutinación lo fue en 1 caso y las pruebas de ELISA lo fueron en 3 ocasiones. Todos los test negativos en la muestra inicial fueron positivos en las muestras tomadas a los mismos pacientes entre 10 y 20 días después, confirmando el diagnóstico de tularemia por seroconversión.

La tabla 5 muestra un resumen de los resultados de cada prueba en cada grupo de pacientes y controles.

Tabla 5: Número de sueros positivos/negativos en cada grupo por pruebas y sensibilidad

\begin{tabular}{|c|c|c|c|c|c|c|}
\hline Test & $\begin{array}{c}\text { Tularemia } \\
\text { confirmada } \\
\text { (364 casos) }\end{array}$ & $\begin{array}{c}\text { Control } \\
\text { negativo } \\
\text { (152 casos) }\end{array}$ & $\begin{array}{l}\text { Sospecha } \\
\text { tularemia } \\
\text { (100 casos) }\end{array}$ & $\begin{array}{l}\text { Brucelosis } \\
\text { (97 casos) }\end{array}$ & $\begin{array}{c}\text { Enfermedades } \\
\text { autoinmunes } \\
\text { (30 casos) }\end{array}$ & $\begin{array}{c}\text { Otras } \\
\text { infecciones } \\
\text { (30 casos) }\end{array}$ \\
\hline CHT & $\begin{array}{l}334 / 30 \\
(91,80 \%)\end{array}$ & $\begin{array}{c}5 / 147 \\
(3,29 \%)\end{array}$ & $\begin{array}{l}5 / 95 \\
(5 \%)\end{array}$ & $\begin{array}{c}15 / 82 \\
(15,46 \%)\end{array}$ & $\begin{array}{c}1 / 29 \\
(3,33 \%)\end{array}$ & $\begin{array}{c}1 / 29 \\
(3,33 \%)\end{array}$ \\
\hline MAT & $\begin{array}{l}332 / 32 \\
(91,20 \%)\end{array}$ & $\begin{array}{l}0 / 152 \\
(0 \%)\end{array}$ & $\begin{array}{l}0 / 100 \\
(0 \%)\end{array}$ & $\begin{array}{c}13 / 84 \\
(13,40 \%)\end{array}$ & $\begin{array}{l}0 / 30 \\
(0 \%)\end{array}$ & $\begin{array}{l}0 / 30 \\
(0 \%)\end{array}$ \\
\hline ELISA IgG & $\begin{array}{l}328 / 36 \\
(90,10 \%)\end{array}$ & $\begin{array}{r}4 / 148 \\
(2,63 \%)\end{array}$ & $\begin{array}{l}8 / 92 \\
(8 \%)\end{array}$ & $\begin{array}{c}15 / 82 \\
(15,46 \%)\end{array}$ & $\begin{array}{c}1 / 29 \\
(3,33 \%)\end{array}$ & $\begin{array}{c}1 / 29 \\
(3,33 \%)\end{array}$ \\
\hline ELISA IgM & $\begin{array}{c}328 / 36 \\
(90,10 \%)\end{array}$ & $\begin{array}{r}4 / 148 \\
(2,63 \%)\end{array}$ & $\begin{array}{l}4 / 96 \\
(4 \%)\end{array}$ & $\begin{array}{c}12 / 85 \\
(12,37 \%)\end{array}$ & $\begin{array}{c}1 / 29 \\
(3,33 \%)\end{array}$ & $\begin{array}{c}1 / 29 \\
(3,33 \%)\end{array}$ \\
\hline
\end{tabular}


En la figura 15 y en la tabla 5 se observa cómo se distribuyen los resultados de cada prueba en los sueros de los pacientes con tularemia, diferenciando resultados positivos y negativos. En la gráfica de microaglutinación se han excluido 275 valores (correspondientes a positivos $>1 / 80$ ) para que se puedan apreciar mejor los falsos negativos.
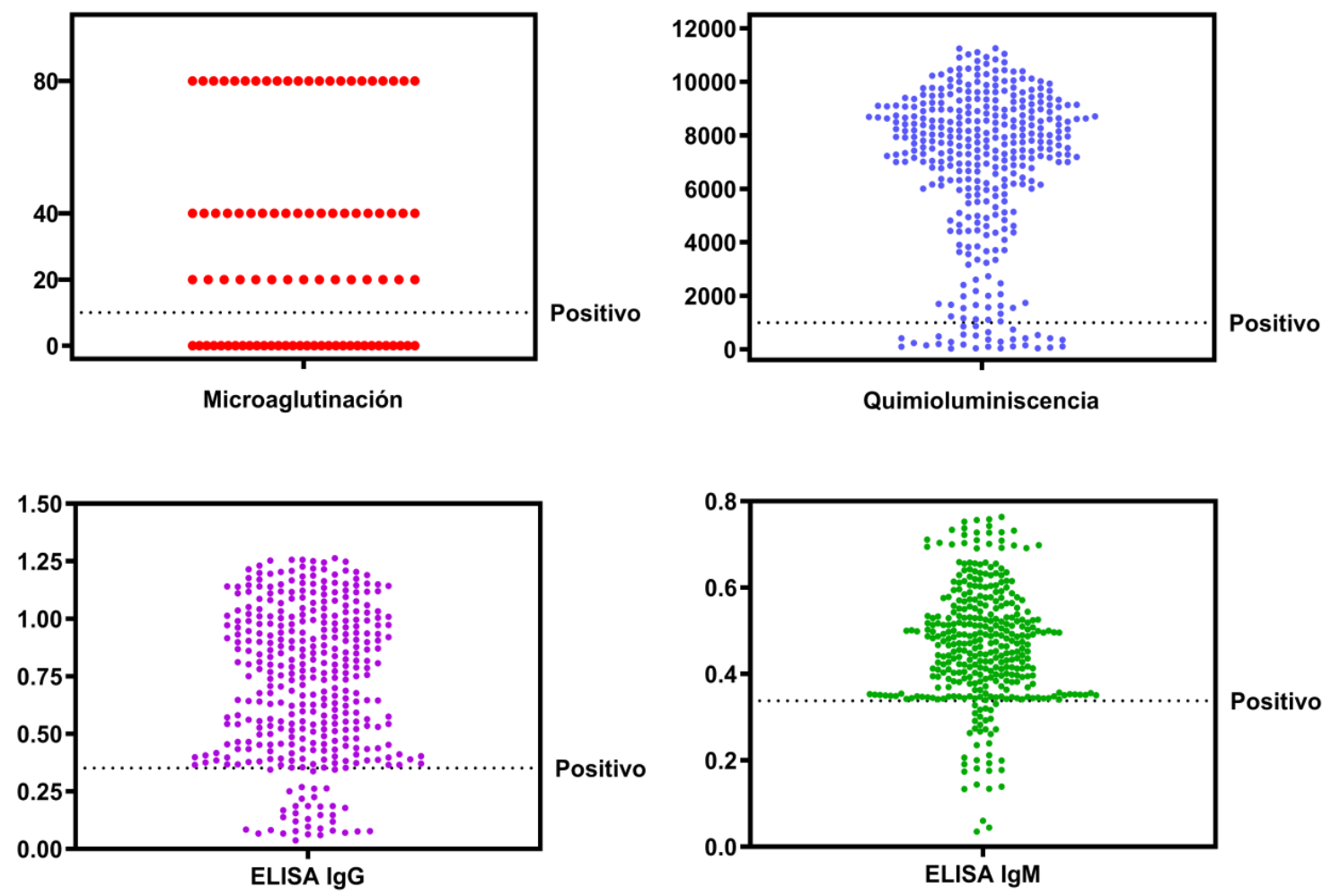

Figura 15: Distribución de resultados obtenidos con los sueros de los pacientes con tularemia por pruebas

Estudiando la sensibilidad de cada una de las pruebas en cada una de las formas clínicas de tularemia encontramos que varía entre el $60 \%$ (tularemia oculoglandular) y el $100 \%$ (tularemia orofaríngea) en las formas clínicas con menor incidencia, y entre el 80,9\% (tularemia ganglionar) y el 94,3\% (tularemia tifoídica) en las de mayor incidencia. Sin embargo, no se observan diferencias significativas entre las sensibilidades obtenidas con las diferentes pruebas ensayadas dentro de cada forma clínica. 
Por otra parte, la sensibilidad obtenida con cada prueba fue similar en todas las formas clínicas, no observándose diferencias significativas cuando se comparan los resultados obtenidos por cada prueba en las diferentes formas clínicas (Tabla 6).

Tabla 6: Sensibilidad de las pruebas serológicas en función de la forma clínica de presentación

\begin{tabular}{l|ccccc}
\hline \multirow{2}{*}{ Forma clínica } & Número (\%) & $\begin{array}{c}\text { CHT } \\
\text { No. (\%) }\end{array}$ & $\begin{array}{c}\text { MAT } \\
\text { No. (\%) }\end{array}$ & $\begin{array}{c}\text { ELISA IgG } \\
\text { No. (\%) }\end{array}$ & $\begin{array}{c}\text { ELISA IgM } \\
\text { No. (\%) }\end{array}$ \\
\hline \multirow{2}{*}{ Tifoídica } & 211 & 199 & 199 & 194 & 197 \\
Glandular & $(58 \%)$ & $(94,3 \%)$ & $(94,3 \%)$ & $(91,9 \%)$ & $(93,4 \%)$ \\
Ulceroglandular & 47 & 40 & 39 & 39 & 38 \\
Neumónica & $(12,9 \%)$ & $(85,1 \%)$ & $(83 \%)$ & $(83 \%)$ & $(80,9 \%)$ \\
Orofaríngea & 55 & 49 & 48 & 49 & 47 \\
& $(15,1 \%)$ & $(89,1 \%)$ & $(87,3 \%)$ & $(89,1 \%)$ & $(85,5 \%)$ \\
Oculoglandular & 28 & 26 & 26 & 25 & 25 \\
& $(7,7 \%)$ & $(92,9 \%)$ & $(92,9 \%)$ & $(89,3 \%)$ & $(89,3 \%)$ \\
No especificado & 12 & 11 & 11 & 12 & 12 \\
& $(1,3 \%)$ & $(91,7 \%)$ & $(91,7 \%)$ & $(100 \%)$ & $(100 \%)$ \\
& 6 & 4 & 3 & 3 & 3 \\
Total & $(1,6 \%)$ & $(83,3 \%)$ & $(100 \%)$ & $(100 \%)$ & $(100 \%)$ \\
\hline & 364 & 334 & 332 & 328 & 328 \\
& $(100,00)$ & $(91,80)$ & $(91,20)$ & $(90,10)$ & $(90,10)$ \\
\hline
\end{tabular}

Del total de sueros iniciales de los pacientes con tularemia, 334 sueros fueron positivos en la prueba de quimioluminiscencia (sensibilidad 91,8\%), 332 (sensibilidad 91,2\%) en microaglutinación y 328 (sensibilidad 90,1\%) en ELISA IgG y en ELISA IgM. (Tablas 6 y 7 ).

Hemos estudiado la especificidad de las diferentes pruebas serológicas, considerando las 152 personas sanas (grupo control negativo) procedentes de las mismas áreas geográficas que los pacientes de tularemia, y encontramos que 5 sueros fueron positivos en quimioluminiscencia (especificidad 96,7\%), 
ningún suero fue positivo en microaglutinación (especificidad 100\%) y 4 sueros fueron positivos en ELISA IgG y en ELISA IgM (especificidad 97,4\%) (Figura 16 y Tablas 5 y 7$)$.

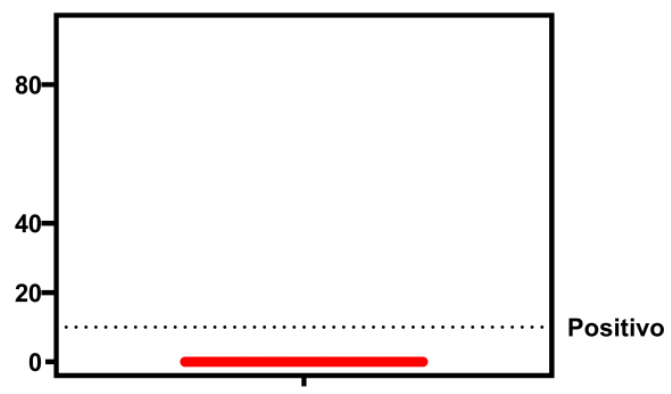

Microaglutinación

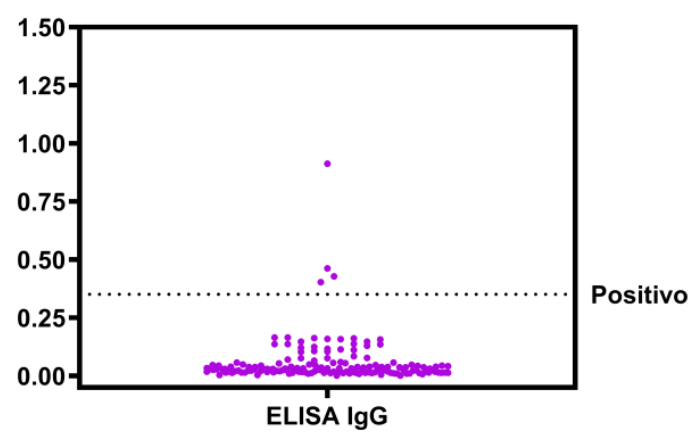

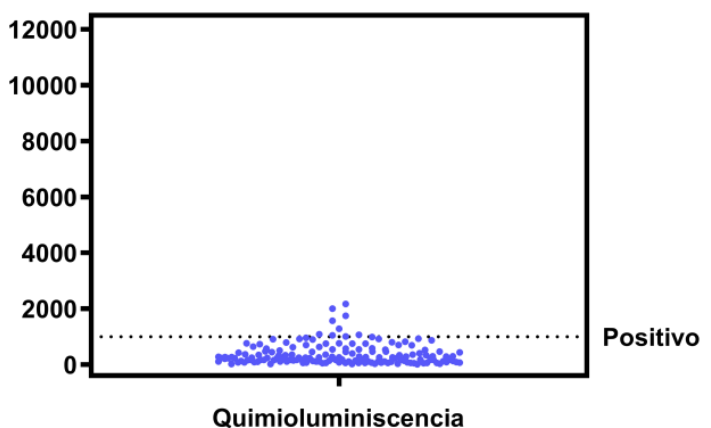

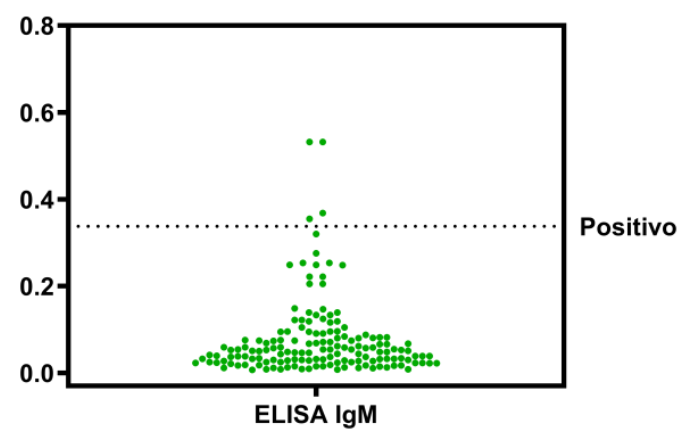

Figura 16: Distribución de resultados obtenidos con los sueros de los pacientes del grupo control negativo por pruebas

La prueba de microaglutinación presentó el mejor valor predictivo positivo (100\%), seguida de las pruebas de ELISA IgG e IgM (98,8\%) y quimioluminiscencia (98,2\%). Por su parte, los mejores resultados para el valor predictivo negativo fueron los de la prueba de quimioluminiscencia (82,9\%), seguido de la microaglutinación (82,6\%) y ELISA IgG e IgM (80,4\%) (Tabla 7).

Los resultados del likelihood ratio positivo son altamente concluyentes (resultados mayores de 10 en todas las pruebas), así como los del likelihood ratio negativo (resultados menores de 0,10 en todas las pruebas) (Tabla 7 ). 
Tabla 7: Sensibilidad, especificidad, valor predictivo y likelihood ratio de las pruebas diagnósticas en los 364 sueros de pacientes con tularemia y en los 152 sueros del grupo control negativo.

\begin{tabular}{|c|c|c|c|c|}
\hline Test & CHT & MAT & ELISA IgG & ELISA IgM \\
\hline Sensibilidad & $\begin{array}{c}91,80 \% \\
(88,8-94,7)\end{array}$ & $\begin{array}{c}91,20 \% \\
(88,2-94,3)\end{array}$ & $\begin{array}{c}90,10 \% \\
(86,9-93,3)\end{array}$ & $\begin{array}{c}90,10 \% \\
(86,9-93,3)\end{array}$ \\
\hline Especificidad & $\begin{array}{c}96,70 \% \\
(92,6-99,5)\end{array}$ & $\begin{array}{c}100 \% \\
(99,7-100)\end{array}$ & $\begin{array}{c}97,40 \% \\
(94,5-100)\end{array}$ & $\begin{array}{c}97,40 \% \\
(94,5-100)\end{array}$ \\
\hline VP positivo & $\begin{array}{c}98,2 \\
(96,7-99,8)\end{array}$ & $\begin{array}{c}100 \\
(99,8-100)\end{array}$ & $\begin{array}{c}98,8 \\
(97,5-100)\end{array}$ & $\begin{array}{c}98,8 \\
(97,5-100)\end{array}$ \\
\hline VP negativo & $\begin{array}{c}82,9 \\
(77,1-88,8)\end{array}$ & $\begin{array}{c}82,6 \\
(76,9-88,4)\end{array}$ & $\begin{array}{c}80,4 \\
(74,4-86,4)\end{array}$ & $\begin{array}{c}80,4 \\
(74,4-86,4)\end{array}$ \\
\hline LR positivo & $\begin{array}{c}23,3 \\
(10,6-50,9)\end{array}$ & $\mathbf{\infty}$ & $\begin{array}{c}34,2 \\
(13,0-90,1)\end{array}$ & $\begin{array}{c}34,2 \\
(13,0-90,1)\end{array}$ \\
\hline LR negativo & $\begin{array}{c}0,09 \\
(0,06-0,12)\end{array}$ & $\begin{array}{c}0,09 \\
0,06-0,12)\end{array}$ & $(0,07-0,14)$ & $(0,07-0,14)$ \\
\hline
\end{tabular}

\section{Eficiencia diagnóstica}

\subsection{Eficiencia diagnóstica de la prueba de quimioluminiscencia}

El área bajo la curva (curva COR) en la prueba de quimioluminiscencia fue de 0,953 (IC: 95\%, 0,935-0,971) (Figura 17 y Tabla 8).

Los mejores resultados de sensibilidad $(91,8 \%)$ y especificidad $(96,2-$ $98,1 \%$ ) se obtienen para valores de Index entre 1037,50 y 1092,50. (Tabla 9). Estos valores son similares a los obtenidos siguiendo las instrucciones de Virclia que establece como valor umbral de positividad un valor de Index de 1000. 


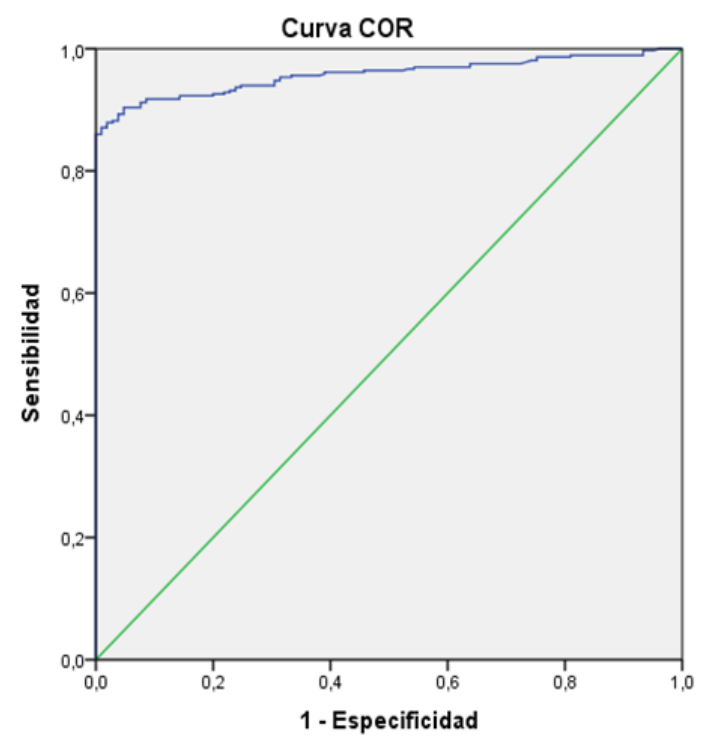

Figura 17: Curva COR Quimioluminiscencia

Tabla 8: Área bajo la curva Quimioluminiscencia

\section{Área bajo la curva}

Variables resultado de contraste:

Quimioluminiscencia

\begin{tabular}{|r|c|r|r|r|}
\hline Área & $\begin{array}{c}\text { Error } \\
\text { típ. }^{\text {Q }}\end{array}$ & $\begin{array}{c}\text { Sig. } \\
\text { asintótica } \\
\text { b }\end{array}$ & \multicolumn{2}{|c|}{$\begin{array}{c}\text { Intervalo de } \\
\text { confianza } \\
\text { asintótico al 95\% }\end{array}$} \\
\cline { 4 - 5 } & & & $\begin{array}{c}\text { Límite } \\
\text { inferior }\end{array}$ & $\begin{array}{c}\text { Límite } \\
\text { superior }\end{array}$ \\
\hline, 953 &, 008 &, 000 &, 935 &, 971 \\
\hline
\end{tabular}

Tabla 9: Coordenadas de la curva

Quimioluminiscencia

Coordenadas de la curva

Variables resultado de contraste: Quimioluminiscencia

\begin{tabular}{|c|c|c|}
\hline $\begin{array}{c}\text { Positivo si es } \\
\text { mayor o igual } \\
\text { que }^{a}\end{array}$ & Sensibilidad & $\begin{array}{c}1- \\
\text { Especificidad }\end{array}$ \\
\hline 8,00 & 1,000 & 1,000 \\
\hline 15,00 & 1,000 & ,990 \\
\hline 21,50 & 1,000 & ,981 \\
\hline 837,50 &, 923 & , 105 \\
\hline 863,50 &, 920 & , 105 \\
\hline 884,50 & ,918 & , 105 \\
\hline 906,00 &, 918 & 095 \\
\hline 920,00 &, 918 & 076 \\
\hline 965,00 &, 918 &, 067 \\
\hline 1004,00 & ,918 & ,057 \\
\hline 1018,50 &, 918 &, 048 \\
\hline 1037,50 &, 918 & 038 \\
\hline 1063,00 &, 918 &, 029 \\
\hline 1092,50 & ,918 &, 019 \\
\hline 1111,50 & ,915 &, 019 \\
\hline 11172,50 &, 005 &, 000 \\
\hline 11247,50 &, 003 &, 000 \\
\hline 11255,00 &, 000 &, 000 \\
\hline
\end{tabular}

\subsection{Eficiencia diagnóstica de la prueba de microaglutinación en placa}

El área bajo la curva (curva COR) en la prueba de microaglutinación fue de 0,956 (IC: 95\%, 0,939-0,974) (Tabla 10). La especificidad de la prueba siempre fue del $100 \%$, pues en el grupo control negativo no se encontraron falsos positivos, razón por la que la curva la curva COR dibuja un modelo completamente recto (Figura 18). 
Los mejores resultados de sensibilidad (91,2\%) y especificidad (100\%) se obtienen para una dilución teórica de 1/10 (Tabla 11). Estos valores de sensibilidad y especificidad a la dilución teórica de 1/10 coinciden con los valores obtenidos con la dilución 1/20 utilizada en nuestro estudio.

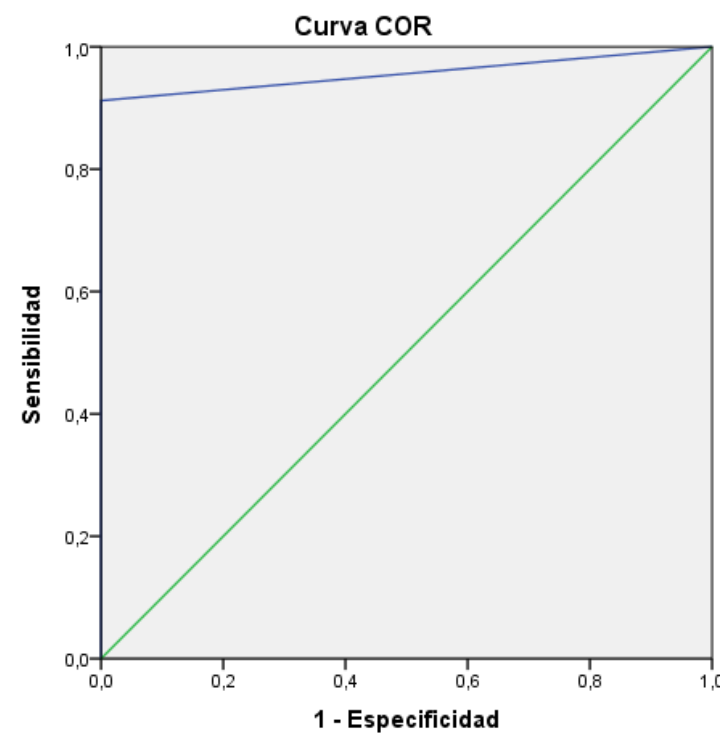

Figura 18: Curva COR Microaglutinación

Tabla 10: Área bajo la curva Microaglutinación

\section{Área bajo la curva}

Variables resultado de contraste:

Microaglutinación

\begin{tabular}{|r|r|r|r|r|}
\hline Área & $\begin{array}{c}\text { Error } \\
\text { típ. }^{\text {a }}\end{array}$ & $\begin{array}{c}\text { Sig. } \\
\text { asintótica }^{\mathrm{b}}\end{array}$ & \multicolumn{2}{|c|}{$\begin{array}{r}\text { Intervalo de } \\
\text { confianza } \\
\text { asintótico al 95\% }\end{array}$} \\
\cline { 4 - 6 } & & & $\begin{array}{c}\text { Límite } \\
\text { inferior }\end{array}$ & $\begin{array}{c}\text { Límite } \\
\text { superior }\end{array}$ \\
\hline, 956 &, 009 &, 000 &, 939 &, 974 \\
\hline
\end{tabular}

Tabla 11: Coordenadas de la curva

Microaglutinación

Coordenadas de la curva

Variables resultado de contraste: Microaglutinación

\begin{tabular}{|r|r|r|}
\hline $\begin{array}{c}\text { Positivo si es } \\
\text { mayor o igual } \\
\text { que }^{\text {a }}\end{array}$ & Sensibilidad & 1 - Especificidad \\
\hline$-1,00$ & 1,000 & 1,000 \\
10,00 &, 912 &, 000 \\
30,00 &, 879 &, 000 \\
60,00 &, 835 &, 000 \\
120,00 &, 777 &, 000 \\
200,00 &, 635 &, 000 \\
280,00 &, 610 &, 000 \\
480,00 &, 462 &, 000 \\
960,00 &, 299 &, 000 \\
1920,00 &, 107 &, 000 \\
3840,00 &, 041 &, 000 \\
7680,00 &, 005 &, 000 \\
10241,00 &, 000 &, 000 \\
\hline
\end{tabular}




\subsection{Eficiencia diagnóstica de las pruebas de ELISA IgG-lgM}

Los valores del área bajo la curva son iguales para ELISA IgG y ELISA IgM 0,970 (IC: 95\%, 0,954-0,986) (Tablas 12 y 14), pero el patrón que dibujan sus respectivas curvas COR es diferente (Figuras 19 y 20).

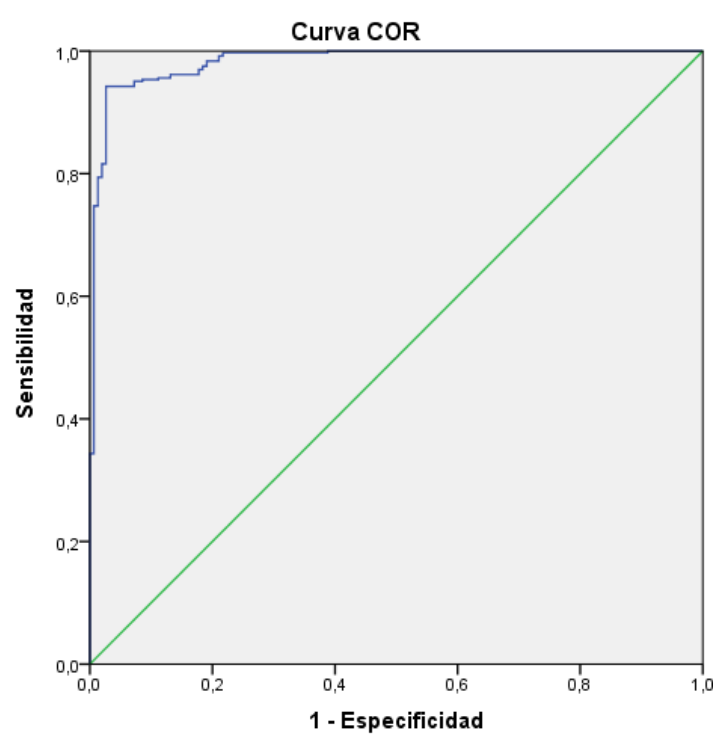

Tabla 13: Coordenadas de la curva ELISA IgG

Coordenadas de la curva

Variables resultado de contraste: ELISA IgG

Figura 19: Curva COR ELISA IgG

Tabla 12: Área bajo la curva ELISA IgG

Área bajo la curva

Variables resultado de contraste: ELISA IgG

\begin{tabular}{|r|r|r|r|r|}
\hline Área & Error & \multicolumn{1}{c|}{$\begin{array}{c}\text { Sig. } \\
\text { típ. }\end{array}$} & & \multicolumn{2}{|c|}{$\begin{array}{c}\text { Intervalo de confianza } \\
\text { asintóticab }\end{array}$} & \multicolumn{2}{|c|}{ asintótico al $95 \%$} \\
\cline { 4 - 5 } & & & $\begin{array}{c}\text { Límite } \\
\text { inferior }\end{array}$ & $\begin{array}{c}\text { Límite } \\
\text { superior }\end{array}$ \\
\hline, 970 &, 008 &, 000 &, 954 &, 986 \\
\hline
\end{tabular}

\begin{tabular}{|c|c|c|}
\hline $\begin{array}{l}\text { Positivo si es } \\
\text { mayor o igual } \\
\text { que }^{\mathrm{a}}\end{array}$ & Sensibilidad & 1 - Especificidad \\
\hline,- 998800 & 1,000 & 1,000 \\
\hline, 002800 & 1,000 & ,987 \\
\hline ,303400 &, 909 &, 026 \\
\hline, 341500 & ,907 &, 026 \\
\hline ,349050 &, 901 &, 026 \\
\hline .353350 & .898 & .026 \\
\hline, 353967 & ,896 &, 026 \\
\hline, 354517 & ,893 &, 026 \\
\hline ,359400 &, 890 &, 026 \\
\hline, 364550 & ,887 &, 026 \\
\hline, 365250 & ,885 &, 026 \\
\hline, 365600 & ,882 &, 026 \\
\hline ,366400 & 879 &, 026 \\
\hline 1,254600 &, 008 &, 000 \\
\hline 1,255900 &, 005 &, 000 \\
\hline
\end{tabular}

En ELISA IgG los mejores resultados de sensibilidad (89,8 - 90,9\%) y especificidad $(97,4 \%)$ se obtienen para valores entre 0,303400 y 0,353350 (Tabla 13). 
Mientras que en ELISA IgM la mejor sensibilidad $(89,8$ - 90,7\%) y especificidad $(97,4 \%)$ corresponde a los valores entre 0,323900 y 0,340350 (Tabla 15).

Estos valores son similares a los que se habían calculado previamente utilizando como umbral de positividad la media +3 ds de un panel de 10 sueros negativos (0,3516 para ELISA IgG y 0,3380 para ELISA IgM).

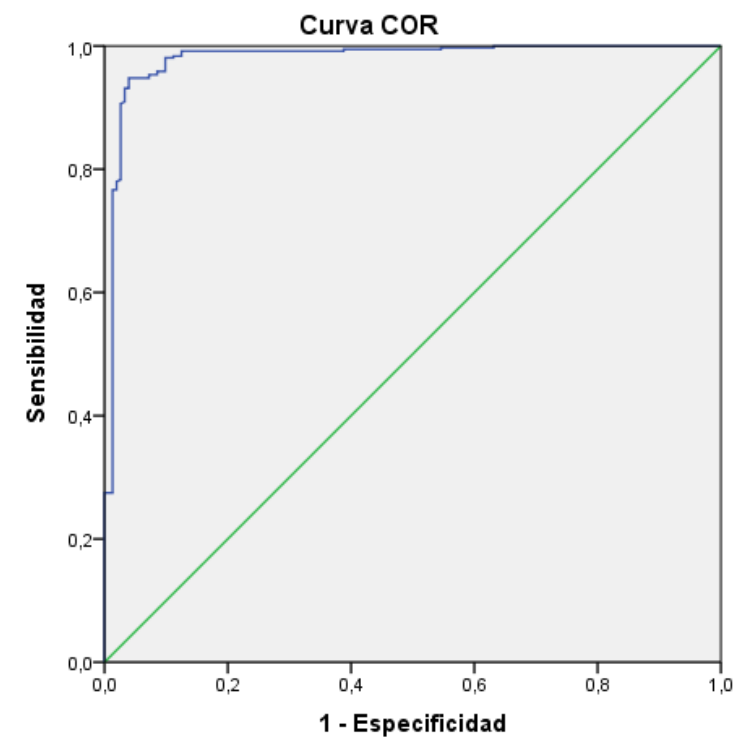

Figura 20: Curva COR ELISA IgM

Tabla 14: Área bajo la curva ELISA IgM

\section{Área bajo la curva}

Variables resultado de contraste: ELISA IgM

\begin{tabular}{|r|r|r|r|r|}
\hline Área & Error & \multicolumn{1}{c|}{$\begin{array}{c}\text { Sig. } \\
\text { típ. }\end{array}$} & & \multicolumn{2}{|c|}{$\begin{array}{c}\text { Intervalo de confianza } \\
\text { asintóticab }\end{array}$} & \multicolumn{2}{|c|}{ asintótico al $95 \%$} \\
\cline { 4 - 5 } & & & $\begin{array}{c}\text { Límite } \\
\text { inferior }\end{array}$ & $\begin{array}{c}\text { Límite } \\
\text { superior }\end{array}$ \\
\hline, 970 &, 008 &, 000 &, 954 &, 986 \\
\hline
\end{tabular}

Tabla 15: Coordenadas de la curva ELISA IgM

\section{Coordenadas de la curva}

Variables resultado de contraste: ELISA IgM

\begin{tabular}{|c|c|c|}
\hline $\begin{array}{l}\text { Positivo si es } \\
\text { mayor o igual } \\
\text { que }^{\Omega}\end{array}$ & Sensibilidad & 1 - Especificidad \\
\hline, 000000 & 1,000 & 1,000 \\
\hline 007450 & 1,000 &, 993 \\
\hline ,305300 & ,918 &, 033 \\
\hline ,312950 & ,915 & 033 \\
\hline ,317000 &, 912 &, 033 \\
\hline ,318650 &, 909 &, 033 \\
\hline ,323900 & ,907 &, 026 \\
\hline, 329250 &, 904 &, 026 \\
\hline ,335350 & 901 &, 026 \\
\hline ,340350 & 898 &, 026 \\
\hline ,341100 & 896 &, 026 \\
\hline ,341600 & 893 &, 026 \\
\hline ,342050 & 890 &, 026 \\
\hline ,342600 &, 885 &, 026 \\
\hline ,343050 & 882 &, 026 \\
\hline ,754450 &, 008 &, 000 \\
\hline ,757150 & 005 &, 000 \\
\hline ,761100 &, 003 & 000 \\
\hline 1,000000 &, 000 & 000 \\
\hline
\end{tabular}




\section{Estudio de especificidad}

Analizando en su conjunto todos los sueros incluidos en el estudio de especificidad de las pruebas observamos que el porcentaje de positividades fue muy bajo en todos los casos (entre el $0 \%$ y el $8 \%$ ) con la excepción de los sueros pacientes con brucelosis donde aumentaron hasta valores cercanos al 15\% (Tabla 16).

Tabla 16: Especificidad de los test diagnósticos en individuos sanos y sueros de pacientes con sospecha de tularemia no confirmada, brucelosis, enfermedades autoinmunes y otras enfermedades infecciosas

\begin{tabular}{|c|c|c|c|c|c|}
\hline Test & $\begin{array}{l}\text { Control } \\
\text { negativo } \\
\text { (152 casos) }\end{array}$ & $\begin{array}{l}\text { Sospecha } \\
\text { tularemia } \\
\text { (100 casos) }\end{array}$ & $\begin{array}{l}\text { Brucelosis } \\
\text { (97 casos) }\end{array}$ & $\begin{array}{l}\text { Enfermedades } \\
\text { autoinmunes } \\
\text { (30 casos) }\end{array}$ & $\begin{array}{c}\text { Otras } \\
\text { infecciones } \\
\text { (30 casos) }\end{array}$ \\
\hline CHT & $5(96,7 \%)$ & 5 (95\%) & $15(84,5 \%)$ & $1(96,7 \%)$ & $1(96,7 \%)$ \\
\hline MAT & 0 (100\%) & 0 (100\%) & $13(86,6 \%)$ & 0 (100\%) & $0(100 \%)$ \\
\hline ELISA IgG & $4(97,4 \%)$ & $8(92 \%)$ & $15(84,5 \%)$ & $1(96,7 \%)$ & $1(96,7 \%)$ \\
\hline ELISA IgM & $4(97,4 \%)$ & 4 (96\%) & $12(87,6 \%)$ & $1(96,7 \%)$ & $1(96,7 \%)$ \\
\hline
\end{tabular}

\subsection{Pacientes con sospecha de tularemia no confirmada $y$ otras patologías}

En el grupo de pacientes con sospecha de tularemia no confirmada, 5 muestras fueron positivas en la prueba de quimioluminiscencia (especificidad del 95\%), ELISA IgG fue positiva en 8 muestras (especificidad del 92\%) y ELISA IgM fue positiva en 4 muestras (especificidad del 96\%), mientras que la microaglutinación fue negativa en todos los sueros (Figura 21). 

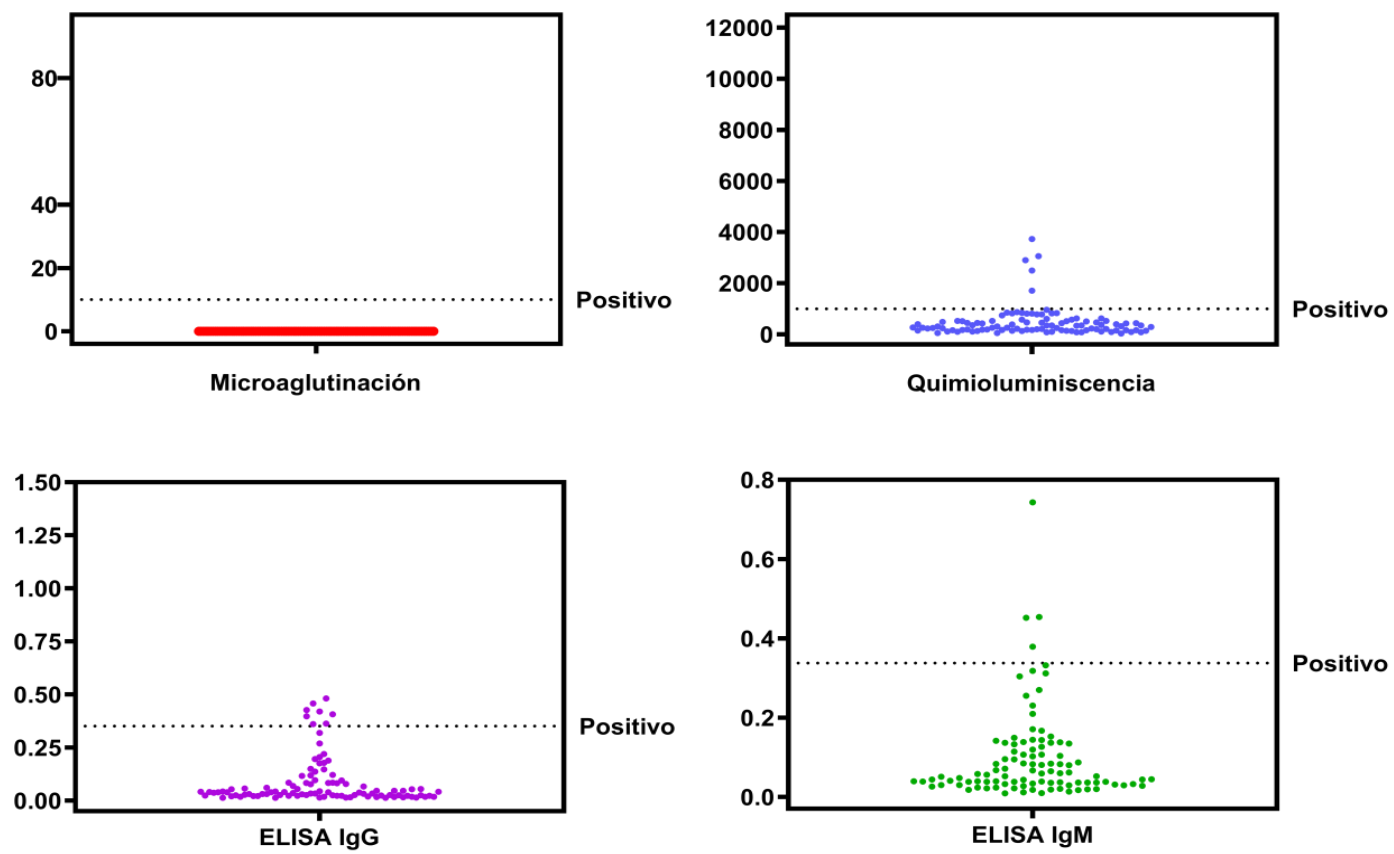

Figura 21: Distribución de resultados obtenidos con los sueros de los pacientes con sospecha de tularemia no confirmada por pruebas

De los 30 pacientes con otras infecciones, solo uno (con fiebre tifoidea) fue positivo en todas las pruebas, excepto en la microaglutinación (Figura 22).
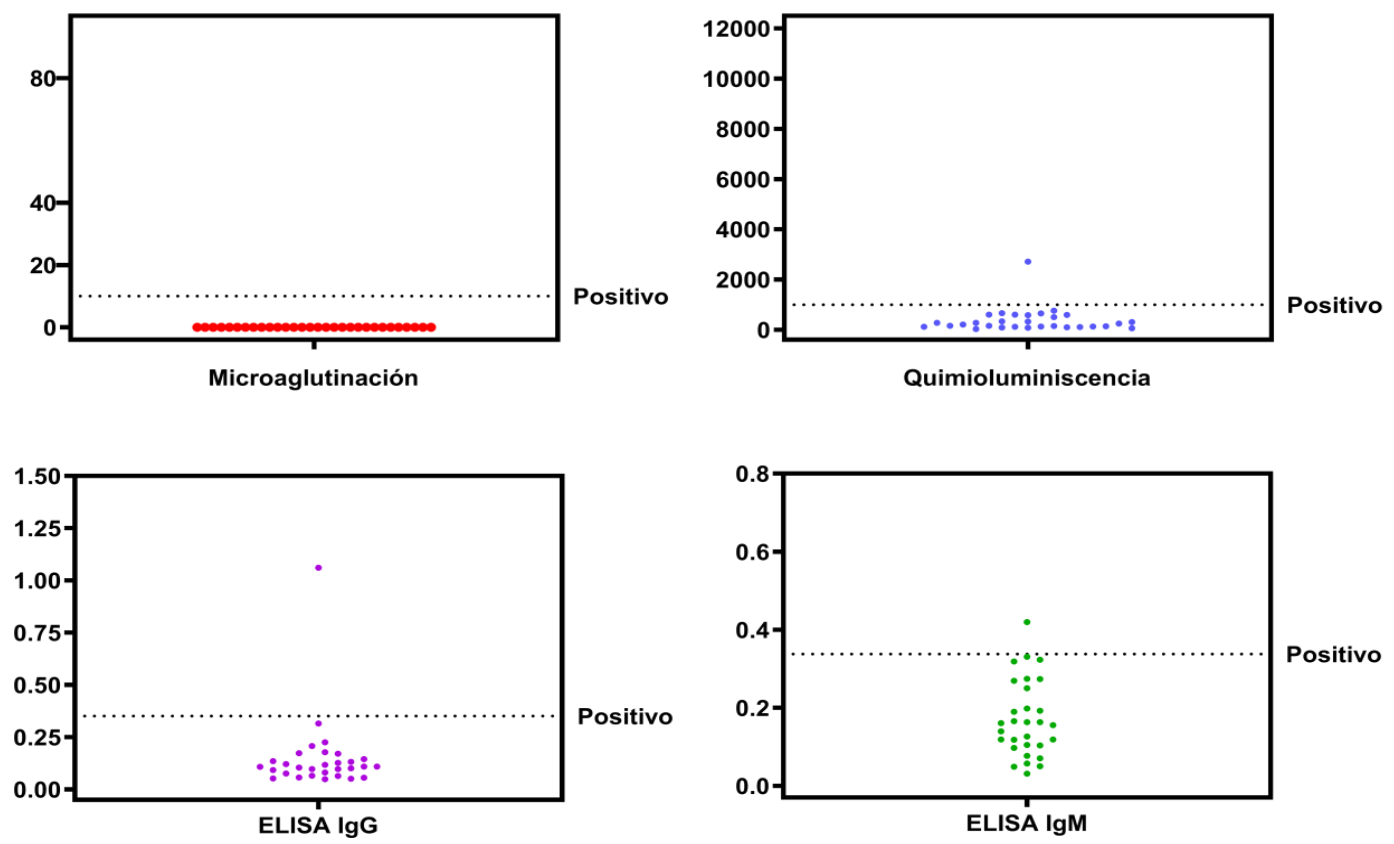

Figura 22: Distribución de resultados obtenidos con los sueros de los pacientes con otras infecciones por pruebas 
De los 30 pacientes con enfermedades autoinmunes, solo un paciente con artritis reumatoide (anticuerpos antinucleares positivos) fue positivo en todas las pruebas, excepto en microaglutinación (Figura 23).
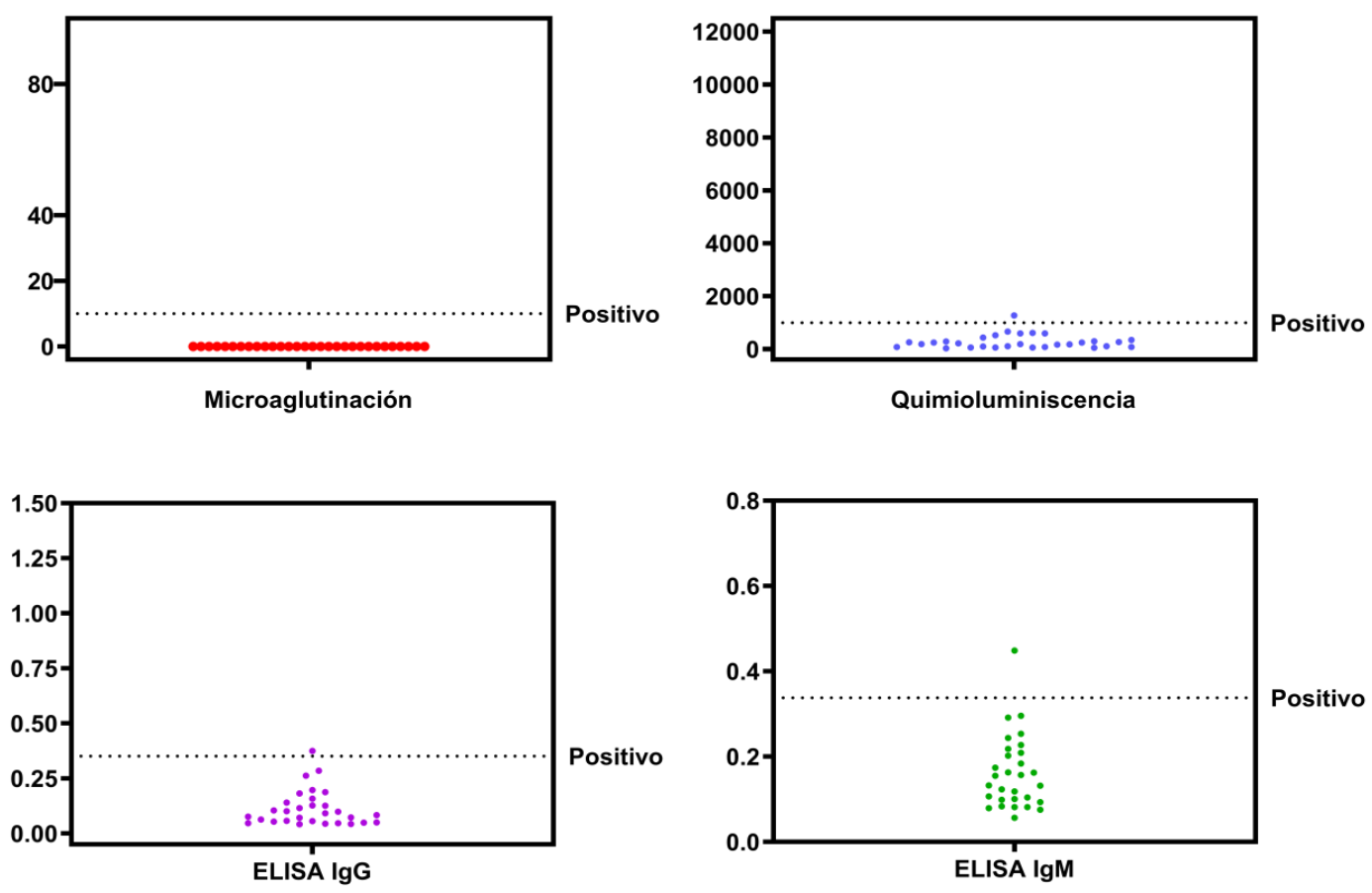

Figura 23: Distribución de resultados obtenidos con los sueros de los pacientes con enfermedades autoinmunes por pruebas

\subsection{Pacientes con brucelosis}

De los 97 sueros con serología positiva para Brucella, 15 sueros (15,5\%) fueron positivos para Francisella tularensis en una o más pruebas serológicas. La prueba de ELISA IgM arrojó el menor número de sueros positivos para Francisella tularensis, con $12,4 \%$ de sueros positivos, seguida de la microaglutinación con un 13,4\%, y ELISA IgG y quimioluminiscencia, ambas con $15,5 \%$ (Figura 24 y Tabla 17). 

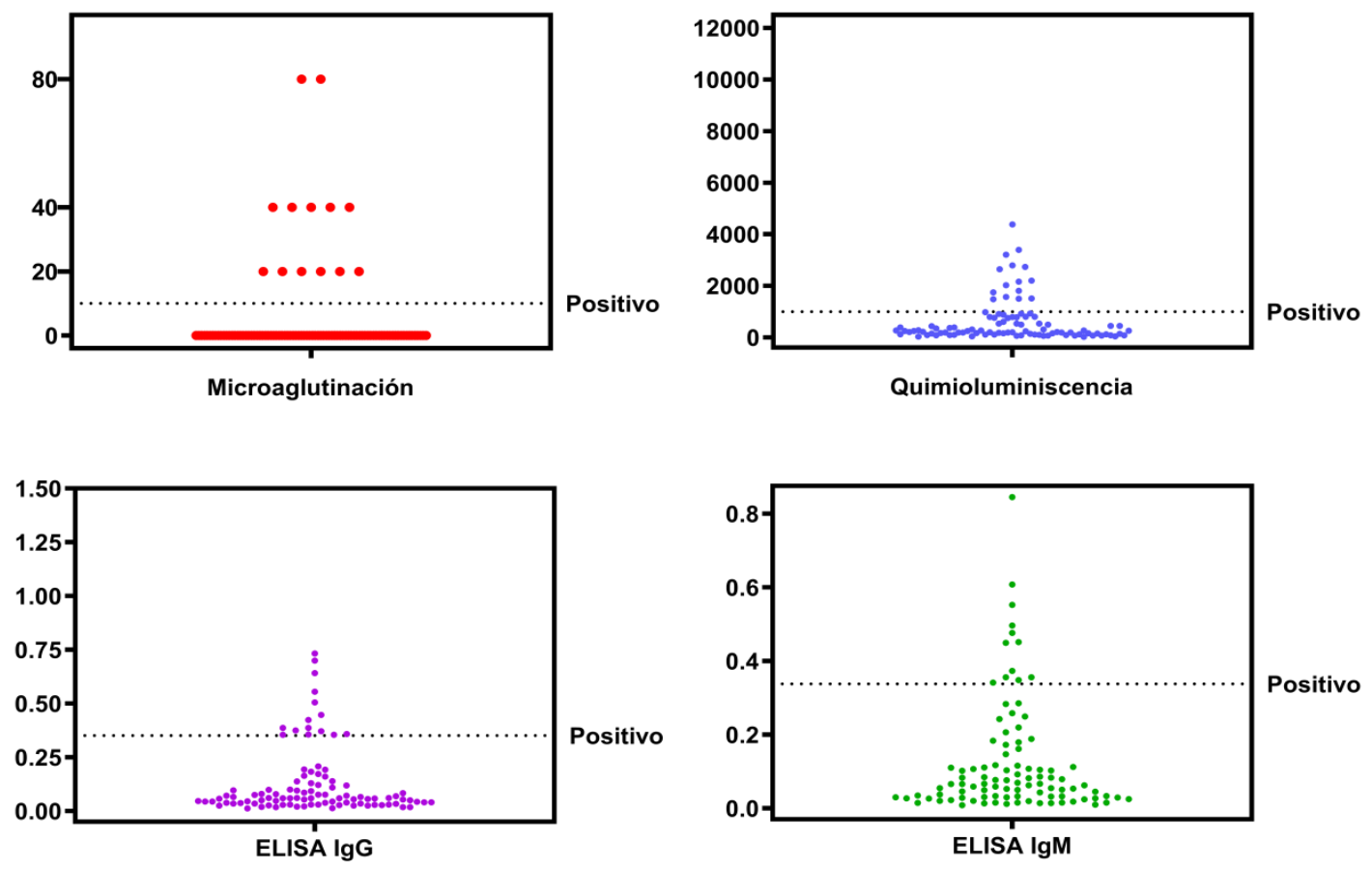

Figura 24: Distribución de resultados obtenidos con los sueros de los pacientes con brucelosis por pruebas

De los 66 sueros de pacientes con brucelosis aguda, $12(18,2 \%)$ presentaron resultados positivos en alguna de las pruebas de Francisella tularensis. De éstos, 9 (13,6\%) fueron positivos en todas las pruebas, siendo un paciente $(1,5 \%)$ negativo en la prueba de microaglutinación y un paciente $(1,5 \%)$ en la prueba de ELISA IgM.

Mientras que, de los cuatro pacientes con recidiva de brucelosis por fracaso del tratamiento, uno fue positivo en todas las pruebas frente a Francisella tularensis; y de los 27 pacientes con brucelosis tratados y curados en los 24 meses anteriores, 2 (7,4\%) fueron positivos en ELISA IgG y quimioluminiscencia, uno de los cuales también fue positivo en microaglutinación. 
Ninguno de los sueros con títulos inferiores a 1/80 en la prueba de Coombs anti-Brucella fue positivo en ninguna de las pruebas serológicas frente a Francisella tularensis. Cuanto más altos fueron los títulos obtenidos en la prueba de Coombs anti-Brucella, mayor fue el porcentaje de seropositividad en todas las pruebas frente a Francisella tularensis; sin embargo, no hubo diferencias estadísticamente significativas (Tabla 17).

Tabla 17: Relación entre títulos en la prueba de Coombs anti-Brucella y resultados en los diferentes test diagnósticos de los 97 sueros con serología positiva para Brucella.

\begin{tabular}{|c|c|c|c|c|c|c|c|c|}
\hline \multirow{2}{*}{$\begin{array}{l}\text { Test Coombs } \\
\text { anti-Brucella }\end{array}$} & \multicolumn{2}{|c|}{ CHT } & \multicolumn{2}{|c|}{ MAT } & \multicolumn{2}{|c|}{ ELISA IgG } & \multicolumn{2}{|c|}{ ELISA IgM } \\
\hline & Positivo & $\begin{array}{l}\text { Negativ } \\
0\end{array}$ & Positivo & $\begin{array}{l}\text { Negativ } \\
0\end{array}$ & Positivo & $\begin{array}{l}\text { Negativ } \\
0\end{array}$ & Positivo & $\begin{array}{c}\text { Negativ } \\
0\end{array}$ \\
\hline $1 / 80$ & $\begin{array}{c}2 \\
(15 \%)\end{array}$ & 11 & $\begin{array}{l}1 \\
(7,7 \%)\end{array}$ & 12 & $\begin{array}{c}2 \\
(15 \%)\end{array}$ & 11 & 0 & 13 \\
\hline $1 / 160$ & $\begin{array}{c}2 \\
(13 \%)\end{array}$ & 13 & $\begin{array}{c}2 \\
(13,3 \%)\end{array}$ & 13 & $\begin{array}{c}2 \\
(13 \%)\end{array}$ & 13 & $\begin{array}{l}1 \\
(6 \%)\end{array}$ & 14 \\
\hline $1 / 320$ & $\begin{array}{c}4 \\
(17 \%)\end{array}$ & 19 & $\begin{array}{c}3 \\
(13 \%)\end{array}$ & 20 & $\begin{array}{c}4 \\
(17 \%)\end{array}$ & 19 & $\begin{array}{c}4 \\
(17 \%)\end{array}$ & 19 \\
\hline $1 / 640$ & $\begin{array}{c}3 \\
(23 \%)\end{array}$ & 10 & $\begin{array}{c}3 \\
(23,1 \%)\end{array}$ & 10 & $\begin{array}{c}3 \\
(23 \%)\end{array}$ & 10 & $\begin{array}{c}3 \\
(23 \%)\end{array}$ & 10 \\
\hline $1 / 1280$ & $\begin{array}{c}4 \\
(19 \%)\end{array}$ & 17 & $\begin{array}{c}4 \\
(19 \%)\end{array}$ & 17 & $\begin{array}{c}4 \\
(19 \%)\end{array}$ & 17 & $\begin{array}{c}4 \\
(19 \%)\end{array}$ & 17 \\
\hline $\begin{array}{l}\text { P valor } \\
<1 / 80- \\
\geq 1 / 80\end{array}$ & 0,391 & & 0,231 & & 0,391 & & 0,115 & \\
\hline Total & $\begin{array}{l}15 \\
(15,5 \%)\end{array}$ & 82 & $\begin{array}{l}13 \\
(13,4 \%)\end{array}$ & 84 & $\begin{array}{l}15 \\
(15,5 \%)\end{array}$ & 82 & $\begin{array}{c}12 \\
(12,4 \%)\end{array}$ & 85 \\
\hline
\end{tabular}




\section{Concordancia entre las pruebas}

Para su análisis hemos optado por utilizar coeficiente kappa de Cohen. En el caso de nuestro estudio, los datos del índice Kappa de Cohen nunca fueron inferiores a 0,70; demostrando que la concordancia entre las diferentes pruebas es buena o muy buena (Tabla 18).

Tabla 18: Resultados del índice Kappa de Cohen y concordancia en las pruebas diagnósticas empleadas

\begin{tabular}{|l|c|c|}
\hline & Índice Kappa de Cohen & Concordancia \\
\hline $\begin{array}{l}\text { Microaglutinación } \\
\text { Quimioluminiscencia }\end{array}$ & 0,824 & Muy Buena \\
\hline Microaglutinación & 0,838 & Muy Buena \\
\hline $\begin{array}{l}\text { Microaglutinación } \\
\text { ELISA IgM }\end{array}$ & 0,903 & Muy Buena \\
\hline $\begin{array}{l}\text { Quimioluminiscencia } \\
\text { ELISA IgG }\end{array}$ & 0,700 & Buena \\
\hline $\begin{array}{l}\text { Quimioluminiscencia } \\
\text { ELISA IgM }\end{array}$ & 0,734 & Buena \\
\hline $\begin{array}{l}\text { ELISA IgG } \\
\text { ELISA IgM }\end{array}$ & 0,877 & Muy Buena \\
\hline
\end{tabular}





\section{DISCUSIÓN}





\section{Sensibilidad pruebas diagnósticas}

Las dificultades que plantea Francisella tularensis para ser aislada en cultivo, el riesgo de accidente que supone su manipulación y la falta de estandarización en las técnicas de PCR, hacen que las técnicas de diagnóstico microbiológico directo sean en general poco utilizadas ${ }^{37,62,170}$.

En nuestro estudio observamos que los resultados que presentan las técnicas indirectas de ELISA y quimioluminiscencia no discrepan respecto a los ensayos serológicos tradicionales, tales como la microaglutinación. Si analizamos los datos más en profundidad vemos que la sensibilidad nunca bajó del $90 \%$, llegando hasta el $91,8 \%$ en quimioluminiscencia y al $90,1 \%$ en ambos tipos de ELISA, mientras que en la microaglutinación en placa alcanzó un $91,2 \%$.

Diversos autores 164,171,172 han encontrado datos de sensibilidad superiores al 95\% utilizando un método de ELISA desarrollado por ellos con el lipopolisacárido purificado como antígeno y basándose en la técnica desarrollada por Porsch-Özcürümez et al. ${ }^{164}$, estos autores obtuvieron una sensibilidad y especificidad del $98 \%$ con una población de 50 controles positivos y 50 controles negativos. Del mismo grupo de investigación es el artículo de Schmitt et al. ${ }^{171}$, en el cual trabajan sobre una muestra de pacientes con tularemia demostrada y otro grupo inmunizado meses antes, encontrando una sensibilidad del $85,3 \%$ para IgG y $89,3 \%$ para IgM en pacientes con tularemia y del $100 \%$ en ambos casos en los pacientes vacunados.

Chaignat et al. ${ }^{172}$, utilizando LPS purificado de Francisella, refieren hasta un $95,6 \%$ de sensibilidad con el método de ELISA desarrollado por ellos y hasta un $97 \%$ con pruebas de ELISA comerciales (cuyo antígeno también es el LPS). Por el contrario, Yanes et al. ${ }^{173}$ describen una sensibilidad de $88,2 \%$ en pruebas comerciales de ELISA-IgM y 86,3\% en ELISA-IgG.

Los bajos resultados de sensibilidad hallados en los estudios de Schmitt ${ }^{171}$ y Yanes ${ }^{173}$ probablemente se deban a que en ambos casos se presentan los datos de lgG e IgM independientemente, mientras que en el caso de 
Schmitt ${ }^{171}$ se suman los resultados de $\lg G$, $\lg M$ e $\lg A$ lo que explica que la sensibilidad aumente hasta un $98,7 \%$.

En lo que respecta a la microaglutinación en placa, la mayoría de estudios utilizan esta técnica como "gold standard" con unos resultados de sensibilidad y especificidad del 100\% 164,172,173. La diferencia entre los resultados de sensibilidad $(91,2 \%)$ de nuestro estudio y los de estos autores puede explicarse por el hecho de que ellos utilizaron muestras de sueros de cada paciente tomadas en diferentes momentos de la evolución de la enfermedad cuando la respuesta inmune ya se había establecido. En muchos casos los sueros se obtuvieron hasta pasadas dos semanas o más desde la aparición de la sintomatología, permitiendo la aparición de anticuerpos y dando lugar a que todos los sueros fueran positivos en la prueba de microaglutinación. Sin embargo, nuestro estudio incluyó solo los sueros iniciales, tomados cuando los pacientes acudieron a la consulta médica por primera vez. Cabe recordar que el brote de tularemia de 1997-1998 fue el primer brote reconocido en España, lo que generó un estado de alarma en la población y que muchos de los pacientes acudieran a las consultas de atención primaria antes de los 7 días posteriores a la aparición de los síntomas.

Ello ha dado lugar a que al analizar nuestros resultados nos encontremos que 18 de los sueros iniciales, lo que equivale a un 4,9\%, fueron negativos en todas las pruebas a pesar de corresponder a pacientes con diagnóstico de tularemia confirmado; que 45 sueros (el 12,4\%) fueron negativos en una o más pruebas y que 35 sueros presentaron resultados de microaglutinación inferiores a 1/80. Estos resultados concuerdan con los obtenidos en otros estudios, como los de Kiliç et al. ${ }^{65}$, que encontraron que solo el $20 \%$ de los sueros obtenidos dentro de los primeros 7 días después del inicio de la enfermedad fueron positivos en pruebas de microaglutinación e inmunocromatografía. Sin embargo, después de 14 días desde la aparición de los síntomas, el porcentaje de sueros positivos aumentó hasta el 82\%. También Yanes et al. ${ }^{173}$ tuvieron en cuenta la evolución de las positividades en función del método diagnóstico. Así durante la primera semana no encontraron ningún positivo con la prueba de microaglutinación y solo el $14,3 \%$ con ELISA, datos 
que aumentaron al $33,3 \%$ y $66,7 \%$ a las 2 semanas y al $75 \%$ y $100 \%$ respectivamente después de 14 días. Es importante tener este detalle en cuenta, ya que un diagnóstico precoz de la tularemia posibilita un tratamiento precoz específico, disminuyendo la gravedad del cuadro clínico, así como la duración de la enfermedad y la convalecencia. De ahí que sea importante conocer que aproximadamente el $9 \%$ de los pacientes que acuden a la consulta pueden ser todavía seronegativos, pero que una segunda muestra de suero tomada unos 10 - 15 días más tarde nos dará casi siempre un resultado positivo en todas las pruebas.

\section{Utilidad de las pruebas diagnósticas}

En el siguiente apartado nos disponemos a analizar los puntos a favor y en contra que presentan las técnicas de ELISA y quimioluminiscencia, así como elaborar una pauta de uso para cada método en función de las circunstancias.

En relación con las pruebas ELISA encontramos que los datos de sensibilidad y especificidad se ven refrendados en todos los valores (tanto en datos bajos como elevados) por los resultados que presenta su área bajo la curva, concretamente 0,970 (IC 95\%, 0,954-0,986) para IgG e IgM; aunque el patrón que dibujan sus respectivas curvas COR es diferente (Figuras 19 y 20), esto se debe a que los puntos de corte entre sensibilidad y especificidad para los distintos valores de la muestra son diferentes entre ambas pruebas, pero el número total de positivos y negativos es el mismo en ambos casos. Por otro lado, Ios altos valores predictivo positivo $(98,8)$ y negativo $(80,4)$ obtenidos nos permiten avalar que los resultados positivos que aparecen en las pruebas van a ser realmente de pacientes enfermos en una proporción muy alta, al menos si los pacientes no tienen antecedentes de tularemia o de brucelosis. También el likelihood ratio positivo y negativo nos demuestra que los resultados de ELISA son altamente concluyentes al superar los valores que demuestran la idoneidad de la prueba. 
Como hemos visto, los resultados de la prueba de quimioluminiscencia Tularemia VirClia IgG+lgM son muy similares a los obtenidos con las pruebas de microaglutinación y ELISA tanto en sensibilidad como en especificidad, también el área bajo la curva está ajustado a unos datos de calidad buenos, concretamente 0,953 (IC 95\%, 0,935 - 0,971). En lo que respecta al valor predictivo positivo la quimioluminiscencia es un $1,8 \%$ inferior a la microaglutinación y en el valor predictivo negativo es la prueba con mejores resultados (82,9). Al igual que en ELISA el likelihood ratio de la quimioluminiscencia entra dentro de la categoría de prueba altamente concluyente tanto para valores positivos como negativos.

Nuestros datos, pues, muestran que tanto las pruebas de ELISA IgG e IgM como la de quimioluminiscencia son buenas técnicas para diagnosticar tularemia humana. Ambas presentan ventajas respecto a las pruebas de aglutinación como la automatización y evitar el fenómeno prozona, si bien son de difícil cuantificación.

Centrándonos en sus características podemos concluir que las pruebas de ELISA son especialmente útiles durante epidemias y en estudios seroepidemiológicos cuando el número de sueros para analizar es elevado, pues se puede analizar un gran número de muestras en cada placa ${ }^{164,171}$. Sin embargo, ofrecen la desventaja de que en los períodos entre epidemias, cuando la tularemia aparece como casos esporádicos, las pruebas de ELISA aumentan de manera considerable los costes asociados al análisis de cada muestra. Esto es debido principalmente a que el tiempo que requieren para su realización es más elevado, y al hecho de que se necesitan varios controles para analizar los resultados de la prueba, concretamente las pruebas comerciales de ELISA requieren entre 3 y 4 controles para interpretar los resultados de la prueba.

Por su parte, la prueba de quimioluminiscencia comercializada por Vircell es más rápida y requiere una menor cantidad de suero para el análisis, al tratarse de cartuchos monotest se consigue que con una sola muestra de suero se lleven a cabo los controles internos necesarios para interpretar los resultados, esta ventaja en su diseño hace que no sean necesarios los 
controles externos por lo que se pueden analizar sueros de manera individual sin disparar los gastos. Uno de los hándicaps que presenta el sistema de quimioluminiscencia es que requiere del uso de un luminómetro adaptado para la lectura e interpretación de los resultados.

\section{Especificidad pruebas diagnósticas}

También se estudió si las diferentes formas clínicas de tularemia presentaban resultados dispares en función de las pruebas diagnósticas utilizadas. Sin embargo, no se encontraron diferencias estadísticamente significativas en ninguno de los casos (Tabla 6), mostrando ELISA y quimioluminiscencia una buena respuesta en todos los casos.

Los resultados de especificidad arrojados por la prueba de quimioluminiscencia en la mayoría de los casos fueron similares a los del resto de las pruebas diagnósticas.

Así, en las pruebas llevadas a cabo sobre los sueros del grupo control negativo (individuos sanos provenientes de zonas endémicas de tularemia) encontramos un $100 \%$ de especificidad con la prueba de microaglutinación. Mientras que ELISA IgG e IgM presentaron un $97,4 \%$ y la quimioluminiscencia un $96,7 \%$. Los estudios de Chaignat ${ }^{172}$ y Yanes ${ }^{173}$ obtuvieron unos resultados inferiores a los obtenidos en nuestro estudio en las diferentes pruebas de ELISA que evalúan. Yanes et al. 173 refieren una sensibilidad desde aproximadamente el $95 \%$ en positivos débiles hasta el $98,5 \%$ con valores positivos más elevados, y Chaignat et al. ${ }^{172}$ consiguen resultados similares a Ios nuestros con los test comerciales de ELISA $(96,8 \%)$, pero sus resultados con el método de ELISA casero obtienen resultados inferiores al $87,2 \%$ en el mejor de los casos.

Con los sueros del grupo de pacientes con sospecha no confirmada de tularemia, pacientes con enfermedades autoinmunes y pacientes con otras enfermedades infecciosas, los resultados de especificidad obtenidos con la 
prueba de quimioluminiscencia son similares a los obtenidos con las demás pruebas, llegando a ser dicha especificidad mayor del $95 \%$ en la mayoría de los casos (Tabla 16).

\section{Reacciones cruzadas}

Sin embargo, la especificidad de todas las pruebas disminuyó considerablemente en pacientes con serología de Brucella positiva, llegando hasta valores cercanos al $85 \%$. Para poder interpretar estos resultados debemos analizarlos de manera estratificada, recordemos que en total se ha trabajado con una batería de 97 sueros de brucelosis confirmada; de los que 66 sueros corresponden a procesos de brucelosis aguda, 4 sueros están relacionados con situaciones de recurrencia de la enfermedad después de haber sido tratada anteriormente y 27 sueros pertenecen a pacientes que contrajeron la brucelosis en los 24 meses anteriores a la obtención del suero pero que en el momento de la misma se encontraban totalmente curados de la enfermedad.

En primer lugar observamos que 2 de los 27 sueros de pacientes con brucelosis tratada y curada en los 24 meses anteriores a la toma de la muestra fueron positivos en las pruebas de quimioluminiscencia y ELISA (7,4\%), y uno $(3,70 \%)$ en las de microaglutinación. Resultados similares a los encontrados por Kiliç et al. 65 en su estudio con técnicas comerciales de inmunocromatografía donde encontró un $8 \%$ de positivos.

Por otra parte, el porcentaje de pacientes con brucelosis aguda que presentaron una serología positiva frente a Francisella tularensis en alguno de los test fue mucho mayor, concretamente del 18.2\% (12 positivos de 66 sueros). Existen pocos estudios que relacionen este tipo de respuesta cruzada, Behan et al. 174 utilizaron técnicas de aglutinación como referencia y encontraron títulos positivos de Francisella tularensis en 8 de 34 sueros de paciente con brucelosis, o lo que es lo mismo, en el $23,52 \%$ de los casos. En la 
misma línea está otro estudio de Kiliç et al. ${ }^{175}$ en el que el porcentaje de sueros positivos disminuyó hasta el 9,1\%.

Si analizamos los resultados en su conjunto, es decir interpretando los datos de los 97 sueros que componen el grupo (tanto los de pacientes con brucelosis actual como con brucelosis curada), nos encontramos que el número de positivos por prueba oscila entre los 12 casos de ELISA IgM $(12,4 \%)$ y los 15 casos de ELISA IgG y quimioluminiscencia (15,5\%).

Además, la positividad en las pruebas serológicas frente a Francisella tularensis ocurrió generalmente en sueros con un nivel de títulos medio o alto en el test de Coombs anti-Brucella, ya que la proporción de positivos en todos los test de tularemia que analizamos fue del $23 \%$ para títulos de $1 / 640$ y del $19 \%$ para títulos de 1/1280. En total encontramos 10 positivos en los sueros con títulos $\geq 1 / 320(9,7 \%)$, una proporción mucho más alta que la encontrada en títulos inferiores a 1/320 (ver tabla 15 en el apartado de resultados). También sucede lo mismo en el estudio de Behan et al. ${ }^{174}$, de hecho en su caso no encuentran títulos de reacciones cruzadas inferiores a 1/640.

Los valores superiores a 1/320 en la prueba de Coombs anti-Brucella servirían potencialmente para el diagnóstico de brucelosis. Que dichos sueros presenten resultados positivos en las pruebas de tularemia provoca una dificultad añadida a la hora de establecer un diagnóstico definitivo. El hecho de que la tularemia humana (especialmente en la forma tifoídica) se presente a menudo con síntomas inespecíficos similares a los de otras enfermedades infecciosas, en particular la brucelosis, y de otra etiología, plantea un problema de diagnóstico. Esto es especialmente relevante en la población de áreas rurales, y entre ganaderos y agricultores, grupos de riesgo entre los que la brucelosis es endémica en muchas regiones y hasta hace pocos años en nuestra región; puesto que son áreas en las que la tularemia se presenta con frecuencia con brotes epidémicos ${ }^{11,13}$. Por ello es importante diferenciar entre la positividad en el resultado de la prueba y el significado que ese título tiene (si es enfermedad actual, recuerdo inmunológico, reacción cruzada o falso positivo), el CDC establece como caso probable de tularemia un título de 1/160, mientras que el test se considera positivo con el título que establezca la 
dilución más baja que dé positiva, esta dilución puede ser de hasta 1/20 en la práctica puesto que la dilución $1 / 10$ no se utiliza habitualmente en las pruebas de seroaglutinación.

En lo que respecta a las reacciones cruzadas con otras enfermedades, los estudios llevados a cabo en Castilla y León no encontraron relación con Yersinia enterocolitica ni con Proteus OX19 ${ }^{155,176}$, aunque otros autores ${ }^{25,177}$ han descrito casos de reacciones cruzadas con los antígenos de estas bacterias.

El principal problema diagnóstico por reacciones cruzadas es entre Brucella y Francisella por cuanto son bacterias que afectan a los mismos grupos de riesgo humanos compartiendo con mucha frecuencia áreas geográficas. Pero, además, no solo los pacientes con brucelosis presentan anticuerpos que reaccionan con las pruebas serológicas de Francisella, si no que sueros de pacientes con tularemia presentan con frecuencia resultados positivos en las pruebas serológicas frente a Brucella ${ }^{143}$. Garrote et al. ${ }^{176}$ encuentran un $9,7 \%$ de positivos en las pruebas de seroaglutinación de Wright (SAW) y en el test de Coombs. 
CONCLUSIONES 

1. La sensibilidad de todas las pruebas diagnósticas en los sueros de pacientes con tularemia confirmada fue superior al $90 \%$ (91,8\% en CHT / 91,20\% en MAT / 90,10\% en ELISA IgG y ELISA IgM).

2. La especificidad de todas las pruebas fue superior al $92 \%$ en los sueros de pacientes con sospecha de tularemia no confirmada (95\% en CHT / $100 \%$ en MAT / $92 \%$ en ELISA IgG / $96 \%$ en ELISA IgM), llegando a valores de más del $97 \%$ cuando fueron testados sobre el grupo control negativo (96,70\% en CHT / 100\% en MAT / 97,4\% en ELISA IgG y ELISA $\lg M)$.

3. Todas las pruebas ensayadas mostraron una correlación buena o muy buena en sus resultados analizándolos con el índice Kappa de Cohen.

4. Todas las pruebas ensayadas presentaron un valor predictivo positivo superior al 98\% (98,2\% en CHT / 100\% en MAT / 98,8\% en ELISA IgG y ELISA IgM) y un valor predictivo negativo próximo al $82 \%(82,9 \%$ en CHT / 82,6\% en MAT / 80,4\% en ELISA IgG y ELISA IgM), de la misma forma que los valores de likelihood ratio fueron altamente concluyentes tanto en valores positivos como negativos para todos los test analizados.

5. Padecer una brucelosis o haberla padecido puede dar origen a serología positiva frente a Francisella, lo que ha de ser tenido en cuenta en algunos casos como motivo de diagnóstico diferencial en función del cuadro clínico y las condiciones epidemiológicas.

6. Los pacientes con otras enfermedades autoinmunes $u$ otras enfermedades infecciosas, en nuestra experiencia, sólo presentaron reacciones cruzadas débiles en el suero de un paciente con artritis reumatoide y en el de un paciente con fiebre tifoidea.

7. La posibilidad de analizar un gran número de sueros al mismo tiempo, así como el menor tiempo de lectura que requieren, hacen que ELISA 
sea la prueba de elección durante epidemias y en estudios seroepidemiológicos.

8. Las pruebas de quimioluminiscencia en monotest han mostrado ser una excelente herramienta para el diagnóstico de la tularemia humana cuando el número de sueros a estudiar es bajo, en particular en los períodos interepidémicos. 
BIBLIOGRAFÍA 

1. Sjöstedt A, Tärnvik A, Sandström G. Francisella tularensis: Host-parasite interaction. FEMS Immunol Med Microbiol. 1996;13(3):181-4.

2. Mccoy GW, Chapin CW. Further Observations on a Plague-Like Disease of Rodents with a Preliminary Note on the Causative Agent, Bacterium Tularense. J Infect Dis. 1912 Jan 1;10(1):61-72.

3. Penn R. Francisella tularensis (Tularemia). In: Mandell, Douglas, Bennett ed Principles and practice of infectious disease. 8. ${ }^{a}$ ed. 2016. p. 2730-42.

4. Weinberg AN. COMMENTARY : Wherry WB, Lamb BH . Infection of man with Bacterium tularense. J Infect Dis. 2004;189:1317-31.

5. Evans ME, Gregory DW, Schaffner W, McGee ZA. Tularemia: a 30-year experience with 88 cases. Medicine (Baltimore). 1985 Jul;64(4):251-69.

6. Sjöstedt A. Tularemia: History, epidemiology, pathogen physiology, and clinical manifestations. Ann N Y Acad Sci. 2007;1105:1-29.

7. Hirschmann J V. From Squirrels to Biological Weapons: The Early History of Tularemia. Vol. 356, American Journal of the Medical Sciences. 2018. p. 319-28.

8. Allred D, Lavender J, Stagg G. Experimental Transmission of Pasteurella tularensis by the Tick, Dermacentor parumapertus. J Infect Dis. 1956;99(2):143-5.

9. Garrity GM. Bergey's manual of systematic bacteriology. Vol. 2, The proteobacteria. Springer; 2004. 100 p.

10. Dennis DT, Inglesby T V, Henderson DA, Bartlett JG, Ascher MS, Eitzen $E$, et al. Tularemia as a biological weapon: medical and public health management. Jama. 2001 Jun;285(21):2763-73.

11. World Health Organization WHO. WHO Guidelines on Tularaemia. 2007. $115 \mathrm{p}$.

12. OIE (World Organisation for Animal Health). Manual de las pruebas de diagnóstico y de las vacunas para los animales terrestres (mamíferos, 
aves y abejas). $7^{a}$ ed. Manual de las pruebas de diagnostico y de las vacunas para los animales terrestres. Office International Des Epizooties; 2012. $1404 \mathrm{p}$.

13. Centro de Coordinación de Alertas y Emergencias sanitarias (CCAES). Informe de situación y evaluación del riesgo de la tularemia en España. 2013;

14. Dempsey MP, Nietfeldt J, Ravel J, Hinrichs S, Crawford R, Benson AK. Paired-end sequence mapping detects extensive genomic rearrangement and translocation during divergence of Francisella tularensis subsp. tularensis and Francisella tularensis subsp. holarctica populations. J Bacteriol. 2006;188(16):5904-14.

15. Maurin M, Gyuranecz M, Infectieux A. Tularaemia: clinical aspects in Europe. Lancet Infect Dis. 2016;16(1):113-24.

16. Keim P, Johansson A, Wagner DM. Molecular epidemiology, evolution, and ecology of Francisella. Ann N Y Acad Sci. 2007;1105:30-66.

17. Gurycova D. First isolation of Francisella tularensis subsp. tularensis in Europe. Eur J Epidemiol. 1998;14(8):797-802.

18. Gurycova D. Epidemiologic characteristics of tularemia in Slovakia. Bratisl Lek Listy. 2006;107(5):224.

19. Vaissaire J, Mendy C. La Tularémie. La maladie et son épidémiologie en France Tularemia. The disease and its epidemiology in France. Médecine Mal Infect. 2005;35:273-80.

20. Sjöstedt A. Intracellular survival mechanisms of Francisella tularensis, a stealth pathogen. Vol. 8, Microbes and Infection. 2006. p. 561-7.

21. Ellis J, Oyston PCF, Green M, Titball RW. Tularemia. ClinMicrobiolRev. 2002;15(0893-8512):631-46.

22. Rowe H, Huntley JF. From the Outside-In: The Francisella tularensis Envelope and Virulence. Front Cell Infect Microbiol. 2015;5(5). 
23. Dueñas Al, Aceves M, Orduña A, Díaz R, Sánchez Crespo M, GarcíaRodríguez C. Francisella tularensis LPS induces the production of cytokines in human monocytes and signals via Toll-like receptor 4 with much lower potency than E. coli LPS. Int Immunol. 2006;18(5):785-95.

24. Kilmury SLN, Twine SM. The Francisella tularensis proteome and its recognition by antibodies. Vol. 1, Frontiers in Microbiology. 2011.

25. Nakajima R, Escudero R, Molina DM, Rodríguez-Vargas M, Randall A, Jasinskas $A$, et al. Towards development of improved serodiagnostics for tularemia by use of francisella tularensis proteome microarrays. J Clin Microbiol. 2016;54(7).

26. Krocova Z, Macela A, Kubelkova K. Innate Immune Recognition: Implications for the Interaction of Francisella tularensis with the Host Immune System. Front Cell Infect Microbiol. 2017 Oct 16;7:446.

27. Celli J, Zahrt TC. Mechanisms of Francisella tularensis intracellular pathogenesis. Cold Spring Harb Perspect Med. 2013 Apr 1;3(4).

28. Kinkead LC, Allen LAH. Multifaceted effects of Francisella tularensis on human neutrophil function and lifespan. Vol. 273, Immunological Reviews. 2016. p. 266-81.

29. Ziveri J, Barel M, Charbit A. Importance of Metabolic Adaptations in Francisella Pathogenesis. Front Cell Infect Microbiol. 2017;7:96.

30. Radomski N, Rebbig A, Leonhardt RM, Knittler MR. Xenophagic pathways and their bacterial subversion in cellular self-defense - таvта $\rho \varepsilon 1$ - everything is in flux. Vol. 308, International Journal of Medical Microbiology. 2018. p. 185-96.

31. Roberts LM, Powell DA, Frelinger JA. Adaptive Immunity to Francisella tularensis and Considerations for Vaccine Development. Front Cell Infect Microbiol. 2018 Apr 6;8(115).

32. Fainboim L, Geffner J. Introducción a la Inmunología Humana. 6ª edición. Buenos Aires: Panamericana; 2013. 
33. Rodríguez Ferri E-F. Tularemia: una aproximación a su estudio integral en Castilla y León. León: Academia de Ciencias Veterinarias de Castilla y León. Junta de Castilla y León; 2017. 353 p.

34. Koskela $P$, Salminen A. Humoral immunity against Francisella tularensis after natural infection. J Clin Microbiol . 1985 Dec 1;22(6):973-9.

35. Picard A, Bano D, Maurin M, Pelloux I, Brion JP, Bano JN Del, et al. Human tularemia in France, 2006-2010. Clin Infect Dis. 2011 Nov;53(10):e133-41.

36. Perez-Castrillon JL, Bachiller-Luque $\mathrm{P}$, Martin-Luquero $\mathrm{M}$, Mena-Martin FJ, Herreros V, Pérez-Castrillón JL, et al. Tularemia epidemic in northwestern Spain: clinical description and therapeutic response. Clin Infect Dis. 2001;33(4):573-6.

37. Evans ME, Friedlander AM. Chapter 24 Tularemia. In: Sidell FR, Takafuji ET, David R. Franz DV., editors. Medical Aspects of Chemical and Biological Warfare. Washington, DC: Office of The Surgeon General at TMM Publications; 1997. p. 503-12.

38. Johansson A, Berglund L, Eriksson U, Göransson I, Wollin R, Forsman M, et al. Comparative analysis of PCR versus culture for diagnosis of ulceroglandular tularemia. J Clin Microbiol. 2000;38(1):22-6.

39. Chitadze N, Kuchuloria T, Clark D V, Tsertsvadze E, Chokheli M, Tsertsvadze $\mathrm{N}$, et al. Water-borne outbreak of oropharyngeal and glandular tularemia in Georgia: investigation and follow-up. Infection. 2009;37(6):514-21.

40. Maurin M, Castan B, Roch N, Gestin B, Pelloux I, Mailles A, et al. RealTime PCR for Diagnosis of Oculoglandular Tularemia. Emerg Infect Dis. 2010;16(1):152-3.

41. Djordjevic-Spasic M, Potkonjak A, Kostic V, Lako B, Spasic Z. Oropharyngeal tularemia in father and son after consumption of undercooked rabbit meat. Scand J Infect Dis. 2011;43(11-12):977-81. 
42. Uyar M, Cengiz B, Unlu M, Celebi B, Kilic S, Eryilmaz A. Evaluation of the oropharyngeal tularemia cases admitted to our hospital from the provinces of Central Anatolia. Mikrobiyol Bul. 2011;45(1):58-66.

43. Sencan I, Sahin I, Kaya D, Oksuz S, Ozdemir D, Karabay O. An outbreak of oropharyngeal tularemia with cervical adenopathy predominantly in the left side. Yonsei Med J. 2009 Feb;50(1):50-4.

44. Willke A, Meric M, Grunow R, Sayan M, Finke EJ, Splettstöber W, et al. An outbreak of oropharyngeal tularaemia linked to natural spring water. $J$ Med Microbiol. 2009;58(1):112-6.

45. Feldman KA, Enscore RE, Lathrop SL, Matyas BT, McGuill M, Schriefer ME, et al. An Outbreak of Primary Pneumonic Tularemia On Martha's Vineyard. N Engl J Med. 2001;345(22):1-6.

46. Ulu-Kilic A, Doganay M. An overview: tularemia and travel medicine. Travel Med Infect Dis. 2014 Jan 1;12(6):609-16.

47. Posautz A, Gyuranecz M, Dénes B, Knauer F, Dier H, Walzer C. Seroprevalence of Francisella tularensis in Austrian Hunting Dogs. Vector-Borne Zoonotic Dis. 2018 Feb;18(2):117-9.

48. Muller W, Hotzel H, Otto P, Karger A, Bettin B, Bocklisch H, et al. German Francisella tularensis isolates from European brown hares (Lepus europaeus) reveal genetic and phenotypic diversity. BMC Microbiol. 2013 Mar;13:61.

49. Goethert HK, Telford SR. Nonrandom distribution of vector ticks (Dermacentor variabilis) infected by Francisella tularensis. PLoS Pathog. 2009;5(2).

50. Lundström JO, Andersson AC, Bäckman S, Schäfer ML, Forsman M, Thelaus J. Transstadial transmission of francisella tularensis holarctica in mosquitoes, Sweden. Emerg Infect Dis. 2011;17(5):794-9.

51. Ryden P, Bjork R, Schafer ML, Lundstrom JO, Petersen B, Lindblom A, et al. Outbreaks of tularemia in a boreal forest region depends on mosquito 
prevalence. J Infect Dis. 2012;205(2):297-304.

52. Anda P, del Pozo JS, Garcia JMD, Escudero R, Pena FJG, Velasco MCL, et al. Waterborne outbreak of tularemia associated with crayfish fishing. Emerg Infect Dis. 2001;7(3 Suppl):575-82.

53. Ryden $\mathrm{P}$, Sjostedt $\mathrm{A}$, Johansson $\mathrm{A}$. Effects of climate change on tularaemia disease activity in Sweden. Glob Health Action. 2009 Nov;2(1).

54. El-Etr SH, Margolis JJ, Monack D, Robison RA, Cohen M, Moore E, et al. Francisella tularensis type $A$ strains cause the rapid encystment of Acanthamoeba castellanii and survive in amoebal cysts for three weeks postinfection. Appl Environ Microbiol. 2009;75(23).

55. Feldman KA, Stiles-Enos D, Julian K, Matyas BT, Telford SR, Chu MC, et al. Tularemia on Martha's Vineyard: Seroprevalence and Occupational Risk. Emerg Infect Dis J. 2003;9(3):350.

56. Servicio de Vigilancia Epidemiológica y Enfermedades Transmisibles. Dirección General de Salud Pública, Investigación D e I. Informe sobre la situación epidemiológica de los casos confirmados de tularemia en Castilla y León. Año 2007. 2008;1-5.

57. Jenzora A, Jansen A, Ranisch H, Lierz M, Wichmann O, Grunow R. Seroprevalence study of Francisella tularensis among hunters in Germany. FEMS Immunol Med Microbiol. 2008;53(2):183-9.

58. Mailles A, Madani N, Maurin M, Garin-Bastuji B, Vaillant V. Excès de cas humains et animaux de tularémie en France au cours de l'hiver 20072008: émergence ou phénomène isolé? Med Mal Infect. 2010;40(5):279_ 84.

59. Pike RM. Laboratory-associated infections: summary and analysis of 3921 cases. Heal Lab Sci. 1976;13(2):105-14.

60. Pike RM. Laboratory-associated infections: incidence, fatalities, causes, and prevention. Annu Rev Microbiol. 1979;33:41-66.

61. Singh K. Laboratory-acquired infections. Clin Infect Dis. 2009;49(1). 
62. López Ramos I, Galván Fernández J, Orduña Domingo A. Fever of unknown origin in a laboratory worker. Enferm Infecc Microbiol Clin. 2018 Oct;36(8):527-8.

63. Switaj K, Olszynska-Krowicka M, Zarnowska-Prymek H, Zaborowski P. Tularaemia after tick exposure - typical presentation of rare disease misdiagnosed as atypical presentation of common diseases: a case report. Cases J. 2009 Jul;2:7954.

64. Revich B, Tokarevich N, Parkinson AJ. Climate change and zoonotic infections in the Russian Arctic. Int J Circumpolar Health. 2012 Jul;71:18792.

65. Kiliç S, Çelebi B, Yeşilyurt M. Evaluation of a commercial immunochromatographic assay for the serologic diagnosis of tularemia. Diagn Microbiol Infect Dis. 2012;74(1):1-5.

66. Whipp MJ, Davis JM, Lum G, de Boer J, Zhou Y, Bearden SW, et al. Characterization of a novicida-like subspecies of Francisella tularensis isolated in Australia. J Med Microbiol. 2003 Sep;52(9):839-42.

67. Jackson J, McGregor A, Cooley L, $\mathrm{Ng} \mathrm{J}$, Brown $\mathrm{M}$, Ong $\mathrm{CW}$, et al. Francisella tularensis Subspecies holarctica, Tasmania, Australia, 2011. Emerg Infect Dis. 2012 Sep;18(9):1484-6.

68. Eden J-S, Rose K, Ng J, Shi M, Wang Q, Sintchenko V, et al. Francisella tularensis ssp. holarctica in Ringtail Possums, Australia. Emerg Infect Dis. 2017 Jul;23(7):1198-201.

69. Njeru J, Tomaso H, Mertens K, Henning K, Wareth G, Heller R, et al. Serological evidence of Francisella tularensis in febrile patients seeking treatment at remote hospitals, northeastern Kenya, 2014-2015. New Microbes New Infect. 2017 Sep;19:62-6.

70. Farlow J, Wagner DM, Dukerich M, Stanley M, Chu M, Kubota K, et al. Francisella tularensis in the United States. Emerg Infect Dis. 2005;11(12):1835-41. 
71. Centers for Disease Control and Prevention (CDC). Tularemia - Missouri, 2000-2007. MMWR Morb Mortal Wkly Rep. 2009;58(27):744-8.

72. Pedati C, House J, Hancock-Allen J, Colton L, Bryan K, Ortbahn D, et al. Notes from the Field: Increase in Human Cases of Tularemia - Colorado, Nebraska, South Dakota, and Wyoming, January-September 2015. MMWR Morb Mortal Wkly Rep. 2015;64(47):1317-8.

73. Tularemia—united states, 1990-2000. JAMA. 2002 Mar 27;287(12):151920.

74. Tularemia - United States, 2001-2010. Morb Mortal Wkly Rep Centers Dis Control Prev MMWR. 2013;62.

75. Statistics | Tularemia | CDC [Internet]. [cited 2019 Feb 6]. Available from: https://www.cdc.gov/tularemia/statistics/index.html

76. Goethert HK, Telford III SR. Quantum of infection of Francisella tularensis tularensis in host-seeking Dermacentor variabilis. Ticks Tick Borne Dis. 2010;1(1).

77. Goethert HK, Shani I, Telford III SR. Genotypic Diversity of Francisella tularensis Infecting Dermacentor variabilis Ticks on Martha's Vineyard, Massachusetts. J Clin Microbiol. 2004;42(11):4968-73.

78. Bystrom M, Bocher S, Magnusson A, Prag J, Johansson A. Tularemia in Denmark: identification of a Francisella tularensis subsp. holarctica strain by real-time PCR and high-resolution typing by multiple-locus variablenumber tandem repeat analysis. J Clin Microbiol. 2005 Oct;43(10):53558.

79. Splettstoesser WD, Mätz-Rensing K, Seibold E, Tomaso H, Al Dahouk S, Grunow R, et al. Re-emergence of Francisella tularensis in Germany: fatal tularaemia in a colony of semi-free-living marmosets (Callithrix jacchus). Epidemiol Infect. 2007;135(8):1256-65.

80. Kaysser P, Seibold E, Matz-Rensing K, Pfeffer M, Essbauer S, Splettstoesser WD. Re-emergence of tularemia in Germany: presence of 
Francisella tularensis in different rodent species in endemic areas. BMC Infect Dis. 2008 Nov;8:157.

81. Müller W, Hotzel H, Otto P, Karger A, Bettin B, Bocklisch H, et al. German Francisella tularensis isolates from European brown hares (Lepus europaeus) reveal genetic and phenotypic diversity. BMC Microbiol. 2013;13(1):61.

82. Schubert A, Splettstoesser W, Bätzing-Feigenbaum J. Tularaemia in Berlin - two independent cases in travellers returning from central Anatolia, Turkey, February 2011. Eurosurveillance. 2011;16(18):2-4.

83. D'Alessandro D, Napoli C, Nusca A, Bella A, Funari E. Human tularemia in Italy. Is it a re-emerging disease? Epidemiol Infect. 2015 Jul;143(10):2161-9.

84. Pilo P, Johansson A, Frey J. Identification of Francisella tularensis cluster in central and western Europe. Emerg Infect Dis. 2009;15(12):2049-51.

85. Lyko C, Chuard C. Tularemia, an emerging disease in Switzerland. Rev Med Suisse. 2013 Oct;9(401):1816-1818,1820.

86. Maraha B, Hajer G, Sjodin A, Forsman M, Paauw A, Roeselers G, et al. Indigenous Infection with Francisella tularensis holarctica in The Netherlands. Case Rep Infect Dis. 2013;2013:916985.

87. Janse I, van der Plaats RQJ, de Roda Husman AM, van Passel MWJ. Environmental Surveillance of Zoonotic Francisella tularensis in the Netherlands. Front Cell Infect Microbiol. 2018 May 8;8:140.

88. Sigaloff KCE, Chung PK, Koopmans J, Notermans DW, van Rijckevorsel GGC, Koene M, et al. First case of severe pneumonic tularemia in an immunocompetent patient in the Netherlands. Neth J Med. 2017 Sep;75(7):301-3.

89. Lopes de Carvalho I, Nascimento P, Núncio MS, Toscano Rico M. First Case of Tularemia Reported in Portugal: Probably of Imported Origin. Front Public Heal. 2018 Nov 19;6:325. 
90. Akhvlediani N, Burjanadze I, Baliashvili D, Tushishvili T, Broladze M, Navdarashvili A, et al. Tularemia transmission to humans: a multifaceted surveillance approach. Epidemiol Infect. 2018 Dec 25;146(16):2139-45.

91. Lang S, Kleines M. Two at one blow: reemergence of tularemia in Upper Austria. New Microbiol. 2012 Jul;35(3):349-52.

92. Vaissaire J, Mendy C, Doujet C Le, Coustumier A Le. Tularemia. The disease and its epidemiology in France. Med Mal Infect. 2005 May;35(5):273-80.

93. Mailles A, Vaillant V. 10 years of surveillance of human tularaemia in France. Euro Surveill. 2014 Nov;19(45):20956.

94. Mailles A, Madani N, Maurin M, Garin-Bastuji B, Vaillant V. Unexpected increase of human and animal tularemia cases during winter 2007/2008 in France: Emergence or short-lasting episode? Med Mal Infect. 2010 May;40(5):279-84 .

95. Hightower J, Kracalik IT, Vydayko N, Goodin D, Glass G, Blackburn JK. Historical distribution and host-vector diversity of Francisella tularensis, the causative agent of tularemia, in Ukraine. Parasit Vectors. 2014 Oct;7:452-3.

96. Eliasson H, Lindback J, Nuorti JP, Arneborn M, Giesecke J, Tegnell A. The 2000 tularemia outbreak: a case-control study of risk factors in disease-endemic and emergent areas, Sweden. Emerg Infect Dis. 2002 Sep;8(9):956-60.

97. Payne L, Arneborn M, Tegnell A, Giesecke J. Endemic tularemia, Sweden, 2003. Emerg Infect Dis. 2005 Sep;11(9):1440-2.

98. Svensson K, Back E, Eliasson H, Berglund L, Granberg M, Karlsson L, et al. Landscape epidemiology of tularemia outbreaks in Sweden. Emerg Infect Dis. 2009;15(12):1937-47.

99. Desvars A, Furberg M, Hjertqvist M, Vidman L, Sjostedt A, Ryden P, et al. Epidemiology and ecology of tularemia in Sweden, 1984-2012. Emerg 
Infect Dis. 2015;21(1):32-9.

100. Wik O. Large tularaemia outbreak in Varmland, central Sweden, 2006. Euro Surveill. 2006 Sep;11(9):E060921.1.

101. Karlsson E, Svensson K, Lindgren P, Bystrom M, Sjodin A, Forsman M, et al. The phylogeographic pattern of Francisella tularensis in Sweden indicates a Scandinavian origin of Eurosiberian tularaemia. Environ Microbiol. 2013 Feb;15(2):634-45.

102. Rossow H, Sissonen S, Koskela KA, Kinnunen PM, Hemmila $H$, Niemimaa $\mathrm{J}$, et al. Detection of Francisella tularensis in voles in Finland. Vector Borne Zoonotic Dis. 2014 Mar;14(3):193-8.

103. Rossow H, Ollgren J, Hytönen J, Rissanen $\mathrm{H}$, Huitu $\mathrm{O}$, Henttonen $\mathrm{H}$, et al. Incidence and seroprevalence of tularaemia in Finland, 1995 to 2013: Regional epidemics with cyclic pattern. Eurosurveillance. 2015;20(33):110.

104. Ekdahl K, Twisselmann B. Epidemics of tularaemia in Sweden and Finland. Euro Surveill. 2001;5(2).

105. Hagen IJ, Aandahl E, Hasseltvedt V. Five case histories of tularaemia infection in Oppland and Hedmark Counties, Norway. Euro Surveill. 2005 Mar;10(3):E050317.4.

106. Brantsaeter AB, Krogh $T$, Radtke A, Nygard K. Tularaemia outbreak in northern Norway. Euro Surveill. 2007 Mar;12(3):E070329.2.

107. Larssen KW, Bergh K, Heier BT, Vold L, Afset JE. All-time high tularaemia incidence in Norway in 2011: report from the national surveillance. Eur J Clin Microbiol Infect Dis. 2014 Nov;33(11):1919-26.

108. Kantardjiev T, Ivanov I, Velinov T, Padeshki P, Popov B, Nenova R, et al. Tularemia outbreak, Bulgaria, 1997-2005. Emerg Infect Dis. 2006;12(4):678-80.

109. Marinov KT, Georgieva ED, Ivanov IN, Kantardjiev T V. Characterization and genotyping of strains of Francisella tularensis isolated in Bulgaria. $J$ 
Med Microbiol. 2009;58(Pt 1):82-5.

110. Pikula J, Treml F, Beklová M, Holešovská Z, Pikulová J. Ecological conditions of natural foci of tularaemia in the Czech Republic. Eur $\mathrm{J}$ Epidemiol. 2003;18(11):1091-5.

111. Cerny Z. Tularemia - An old and a new problem in the South Moravia Region. Bratisl Lek Listy. 2000;101(7):402-8.

112. Cerny Z. Changes of the epidemiology and the clinical picture of tularemia in Southern Moravia (the Czech Republic) during the period 1936-1999. Eur J Epidemiol. 2001;17(7):637-42.

113. Gyuranecz M, Reiczigel J, Krisztalovics K, Monse L, Szabone GK, Szilagyi $A$, et al. Factors influencing emergence of tularemia, Hungary, 1984-2010. Emerg Infect Dis. 2012;18(8):1379-81.

114. Kreizinger Z, Hornok S, Dan A, Hresko S, Makrai L, Magyar T, et al. Prevalence of Francisella tularensis and Francisella-like endosymbionts in the tick population of Hungary and the genetic variability of Francisellalike agents. Vector Borne Zoonotic Dis. 2013 Mar;13(3):160-3.

115. Grunow R, Kalaveshi A, Kuhn A, Mulliqi-Osmani G, Ramadani N. Surveillance of tularaemia in Kosovo, 2001 to 2010. Euro Surveill. 2012 Jul;17(28):20217.

116. Reintjes R, Dedushaj I, Gjini A, Jorgensen TR, Cotter B, Lieftucht A, et al. Tularemia outbreak investigation in Kosovo: case control and environmental studies. Emerg Infect Dis. 2002;8(1):69-73.

117. Grunow R, Finke EJ. A procedure for differentiating between the intentional release of biological warfare agents and natural outbreaks of disease: its use in analyzing the tularemia outbreak in Kosovo in 1999 and 2000. Clin Microbiol Infect. 2002;8(8):510-21.

118. Zajmi D, Berisha M, Kalaveshi A, Begolli I, Ramadani N, Hoxha R. Epidemiological characteristics of tularemia in kosova in the period 20062011. Mater Sociomed. 2013;25(4):220-2. 
119. Tarnvik A, Priebe HS, Grunow R. Tularaemia in Europe: an epidemiological overview. Scand J Infect Dis. 2004;36(5):350-5.

120. Dudarev AA, Dorofeyev VM, Dushkina E V, Alloyarov PR, Chupakhin VS, Sladkova YN, et al. Food and water security issues in Russia III: foodand waterborne diseases in the Russian Arctic, Siberia and the Far East, 2000-2011. Int J Circumpolar Health. 2013;72:21856.

121. Revich B, Tokarevich N, Parkinson AJ. Climate change and zoonotic infections in the Russian Arctic. Int $J$ Circumpolar Health. 2012;71(6):18792.

122. Gutierrez MP, Orduña A, Dueñas A, Bratos MA, Almaraz A, Alamo R, et al. Prevalence of antibodies against Francisella tularensis in Castilla y Leon (Spain) before 1997. Med Clin (Barc). 2003 Feb;120(3):97-8.

123. Allue M, Sopena CR, Gallardo MT, Mateos L, Vian E, Garcia MJ, et al. Tularaemia outbreak in Castilla y Leon, Spain, 2007: an update. Euro Surveill. 2008;13(32):18948.

124. Martin C, Gallardo MT, Mateos L, Vian E, Garcia MJ, Ramos J, et al. Outbreak of tularaemia in Castilla y Leon, Spain. Euro Surveill. 2007 Nov;12(11):E071108.1.

125. Aldea-Mansilla C, Nebreda T, de Cruz SG, Dodero E, Escudero R, Anda $P$, et al. Tularemia: a decade in the province of Soria (Spain). Enferm Infecc Microbiol Clin. 2010;28(1):21-6.

126. Ariza-Miguel J, Johansson A, Fernandez-Natal Ml, Martinez-Nistal C, Orduña A, Rodriguez-Ferri EF, et al. Molecular investigation of tularemia outbreaks, Spain, 1997-2008. Emerg Infect Dis. 2014 May;20(5):754-61.

127. Larssen KW, Afset JE, Heier BT, Krogh T, Handeland K, Vikoren T, et al. Outbreak of tularaemia in central Norway, January to March 2011. Euro Surveill. 2011 Mar;16(13):19828.

128. Hukić $M$, Numanović $F$, Šiširak $M$, Moro A, Dervović $E$, Jakovac $S$, et al. Surveillance of wildlife zoonotic diseases in the Balkans Region. Med 
Glas (Zenica). 2010;7(2):96-105.

129. Rodríguez-Pastor R, Escudero R, Vidal D, Mougeot F, Arroyo B, Lambin $X$, et al. Density-Dependent Prevalence of Francisella tularensis in Fluctuating Vole Populations, Northwestern Spain. Emerg Infect Dis. 2017 Aug;23(8):1377-9.

130. García Del Blanco N, Dobson ME, Vela Al, De La Puente VA, Gutiérrez $\mathrm{CB}$, Hadfield TL, et al. Genotyping of Francisella tularensis strains by pulsed-field gel electrophoresis, amplified fragment length polymorphism fingerprinting, and 16S rRNA gene sequencing. J Clin Microbiol. 2002;40(8).

131. Ohara $\mathrm{Y}$, Sato $\mathrm{T}$, Homma M. Epidemiological analysis of tularemia in Japan (yato-byo). FEMS Immunol Med Microbiol. 1996;13(3):185-9.

132. Gurcan S. Epidemiology of tularemia. Balkan Med J. 2014 Mar;31(1):310.

133. Akalin $\mathrm{H}$, Helvaci $\mathrm{S}$, Gedikoglu $\mathrm{S}$. Re-emergence of tularemia in Turkey. Int J Infect Dis. 2009 Sep;13(5):547-51.

134. Helvaci S, Gedikoglu S, Akalin H, Oral HB. Tularemia in Bursa, Turkey: 205 cases in ten years. Eur J Epidemiol. 2000 Mar;16(3):271-6.

135. Centers for Disease Control. Case Definitions for Infectious Conditions. Vol. 46. 1997.

136. Protocolos de la red nacional de vigilancia epidemiológica. Madrid: Red Nacional de Vigilancia Epidemiológica, Instituto de Salud Carlos III, CIBER Epidemiología y Salud Pública (CIBERESP); 2015.

137. Guide pour l'investigation épidémiologique. Tularémie. Institut de Veille Sanitaire. Santé Publique France; 2001. p. 1-5.

138. Tularemia Investigation Guideline. Kansas: Department of Health and Environment; 2015. p. 1-15.

139. Alberta Health. Notifiable Disease Report (NDR) Manual. Alberta; 2015. 
140. CDC. Basic laboratory protocols for the presumptive Francisella tularensis. 2001. p. 1-16.

141. Johansson $A$, Forsman $M$, Sjöstedt $A$. The development of tools for diagnosis of tularemia and typing of Francisella tularensis. APMIS. 2004;112(11-12):898-907.

142. Gyuranecz M, Szeredi L, Makrai L, Fodor L, Mészáros ÁR, Szépe B, et al. Tularemia of European brown hare (lepus europaeus): A pathological, histopathological, and immunohistochemical study. Vet Pathol. 2010;47(5).

143. Dueñas Al, Ortega $M$, Garrote I, de Frutos $M$, Gutiérrez P, GarcíaPascual $A$, et al. Diagnóstico de laboratorio y evolución serológica de pacientes con tularemia. Med Clin (Barc). 2000;114(11):407-10.

144. Viljanen MK, Nurmi T, Salminen A. Enzyme-linked immunosorbent assay (ELISA) with bacterial sonicate antigen for $\lg M, \lg A$, and $\lg G$ antibodies to Francisella tularensis: Comparison with bacterial agglutination test and ELISA with lipopolysaccharide antigen. J Infect Dis. 1983;148(4):715-20.

145. Koskela P. Humoral immunity induced by a live Francisella tularensis vaccine. Complement fixing antibodies determined by an enzyme-linked immunosorbent assay (CF-ELISA). Vaccine. 1985;3(5):389-91.

146. Carlsson HE, Lindberg AA, Lindberg G, Hederstedt B, Karlsson K-A, Agell BO. Enzyme-Linked Immunosorbent Assay for Immunological Diagnosis of Human Tularemia. J Clin Microbiol. 1979 Nov 1;10(5):615-21.

147. Boisset S, Caspar Y, Sutera V, Maurin M. New therapeutic approaches for treatment of tularaemia: A review. Front Cell Infect Microbiol. 2014;5(MAR).

148. Conlan JW. Tularemia vaccines: Recent developments and remaining hurdles. Future Microbiol. 2011;6(4):391-405.

149. Place DE, Williamson DR, Yuzefpolskiy Y, Katkere B, Sarkar S, Kalia V, et al. Development of a novel Francisella tularensis live vaccine strain 
expressing ovalbumin provides insight into antigen-specific CD8+T cell responses. PLoS One. 2017 Dec 28;12(12).

150. Jia $Q$, Bowen R, Dillon BJ, Masleša-Galić $S$, Chang BT, Kaidi AC, et al. Single vector platform vaccine protects against lethal respiratory challenge with Tier 1 select agents of anthrax, plague, and tularemia. Sci Rep. 2018 Dec 3;8(1):7009.

151. Jia Q, Horwitz MA. Live Attenuated Tularemia Vaccines for Protection Against Respiratory Challenge With Virulent F. tularensis subsp. tularensis. Front Cell Infect Microbiol. 2018 May 15;8:154.

152. Mechaly A, Vitner E, Levy H, Weiss S, Bar-David E, Gur D, et al. Simultaneous Immunodetection of Anthrax, Plague, and Tularemia from Blood Cultures by Use of Multiplexed Suspension Arrays. J Clin Microbiol. 2018 Jan 31;56(4).

153. Dunbar J, Gallegos-Graves LV, Gans J, Morse SA, Pillai S, Anderson K, et al. Evaluation of DNA extraction methods to detect bacterial targets in aerosol samples. J Microbiol Methods. 2018 Oct;153:48-53.

154. McClellan G, Coleman M, Crary D, Thurman A, Thran B. Human DoseResponse Data for Francisella tularensis and a Dose- and TimeDependent Mathematical Model of Early-Phase Fever Associated with Tularemia After Inhalation Exposure. Risk Anal. 2018 Aug;38(8):1685700 .

155. Gutiérrez MP, Bratos MA, Garrote Jl, Dueñas A, Almaraz A, Alamo R, et al. Serologic evidence of human infection by Francisella tularensis in the population of Castilla y Leon (Spain) prior to 1997. FEMS Immunol Med Microbiol. 2003 Mar;35(2):165-9.

156. Garrote $\mathrm{JI}$, Gutiérrez MP, Izquierdo RL, Dueñas MAI, Zarzosa $P$, Canavate $\mathrm{C}$, et al. Seroepidemiologic study of Leishmania infantum infection in Castilla-Leon, Spain. Am J Trop Med Hyg. 2004;71(4):403-6.

157. Corbel MJ. Brucellosis in humans and animals. WHO. 2006. p. 1-102. 
158. Centers for Disease Control and Prevention (CDC). Brucellosis Reference Guide: Exposures, Testing and Prevention. 2017.

159. Brown SL, McKinney FT, Klein GC, Jones WL. Evaluation of a safraninO-stained antigen microagglutination test for Francisella tularensis antibodies. J Clin Microbiol. 1980;11(2):146-8.

160. Sato $T$, Fujita $H$, Ohara $Y$, Homma M. Microagglutination test for early and specific serodiagnosis of tularemia. J Clin Microbiol. 1990;28(10):2372-4.

161. Westphal O, Jann K. Bacterial Lipopolysaccharides: Extraction with phenol-water and further applications of the procedure. Methods Carbohydr Chem Whistler, RL, ed, Acadamic Press New York. 1965;5:83-91.

162. Fulop MJ, Webber T, Manchee RJ, Kelly DC. Production and Characterization of Monoclonal Antibodies Directed against the Lipopolysaccharide of Francisella tularensis. J Clin Microbiol. 1991;29(7):1407-12.

163. Sandström G, Sjöstedt A, Johansson T, Kuoppa K, Williams J. Immunogenicity and toxicity of lipopolysaccharide from Francisella tularensis LVS. FEMS Microbiol Immunol. 1992;5(4):201-10.

164. Porsch-Ozcürümez $M$, Kischel N, Priebe $H$, Splettstösser W, Finke E-J, Grunow R. Comparison of enzyme-linked immunosorbent assay, Western blotting, microagglutination, indirect immunofluorescence assay, and flow cytometry for serological diagnosis of tularemia. Clin Diagn Lab Immunol. 2004;11(6):1008-15.

165. Créton R, Jaffe LE. Chemiluminescence microscopy as a tool in biomedical research. Vol. 31, BioTechniques. 2001. p. 1098-105.

166. Cinquanta L, Fontana DE, Bizzaro N. Chemiluminescent immunoassay technology: what does it change in autoantibody detection? Autoimmun Highlights. 2017 Dec 24;8(1):9. 
167. Wang YF, Kobayashi M. Antibody Detection: Principles and Applications. In: Advanced Techniques in Diagnostic Microbiology. Boston, MA: Springer US; 2013. p. 53-73.

168. Su Y, Chen H, Wang Z, Lv Y. Recent advances in chemiluminescence. Vol. 42, Applied Spectroscopy Reviews. 2007. p. 139-76.

169. Kricka LJ. Clinical applications of chemiluminescence. In: Analytica Chimica Acta. 2003. p. 279-86.

170. Splettstoesser W, Guglielmo-Viret V, Seibold E, Thullier P. Evaluation of an immunochromatographic test for rapid and reliable serodiagnosis of human tularemia and detection of Francisella tularensis-specific antibodies in sera from different mammalian species. J Clin Microbiol. 2010;48(5):1629-34.

171. Schmitt $P$, Splettstösser $W$, Porsch-Özcürümez M, Finke EJ, Grunow R. A novel screening ELISA and a confirmatory Western blot useful for diagnosis and epidemiological studies of tularemia. Epidemiol Infect. 2005;133(4):759-66.

172. Chaignat V, Djordjevic-Spasic M, Ruettger A, Otto P, Klimpel D, Müller W, et al. Performance of seven serological assays for diagnosing tularemia. BMC Infect Dis. 2014;14(1):234.

173. Yanes H, Hennebique A, Pelloux I, Boisset S, Bicout DJ, Caspar Y, et al. Evaluation of in-house and commercial serological tests for diagnosis of human tularemia. J Clin Microbiol. 2018;56(1).

174. Behan KA, Klein GC. Reduction of Brucella species and Francisella tularensis cross-reacting agglutinins by dithiothreitol. J Clin Microbiol. 1982 Oct;16(4):756-7.

175. Kiliç S, Celebi B, Bayram Y, Citil B. Investigation of cross-reactions with Francisella tularensis antibodies to Brucella. Turkish Bull Hyg Exp Biol. 2013;70(2):65-70.

176. Garrote Moreno JI, Orduña Domingo A dir. Utilidad en el diagnóstico y en 
estudios seropidemiológicos en atención primaria de la serologia frente a la tularemia : estudio seroepidemiológico en Castilla y León / José Ignacio Garrote Moreno; trabajo realizado bajo la dirección de Antonio Orduña Domingo y Purificación Gutiérrez Rodríguez. [s.I. : s.n.]; 2006.

177. Golkocheva-Markova E, Christova I, Stoilov R, Najdenski H. Crossreaction between Yersinia outer membrane proteins and anti- Borrelia antibodies in sera of patients with Lyme disease. Clin Microbiol Infect. 2008 Sep;14(9):873-5. 

ANEXOS 



\title{
Usefulness of a single-assay chemiluminescence test (Tularaemia VIRCLIA IgG + IgM monotest) for the diagnosis of human tularemia. Comparison of five serological tests
}

\author{
África Cubero ${ }^{1} \cdot$ Carlos Durántez $^{1} \cdot$ Ana Almaraz ${ }^{1} \cdot$ Luis Fernández-Lago $^{2} \cdot$ María P. Gutiérrez $^{1} \cdot$ María J. Castro $^{3}$. \\ Miguel A. Bratos ${ }^{1,4}$ - María Simarro ${ }^{1}$ - Gabriel A. March ${ }^{1,4}$. Antonio Orduña ${ }^{1,4}$
}

Received: 4 September 2017 / Accepted: 28 November 2017 / Published online: 27 December 2017

C Springer-Verlag GmbH Gemany, part of Springer Nature 2017

\begin{abstract}
The aim of this work was to ascertain the usefulness of a new commercially-available single-assay chemiluminescence test (CHT) for the diagnosis of human tularemia (Tularaemia VIRCLIA IgG + IgM monotest, Vircell, Santa Fe, Granada, Spain). A total of 773 sera from 773 patients including 364 initial sera from patients with diagnosed tularemia, patients with suspected tularemia not confirmed (100), healthy people (152), patients with serology positive to Brucella (97), patients diagnosed with other infectious diseases (30), and patients diagnosed with autoimmune diseases (30) were included. All sera were tested by CHT, "in-house" microagglutination test (MAT), immunochromatographic test (ICT) (Virapid Tularaemia, Vircell, Santa Fe Granada, Spain), and "in-house" ELISA IgG, and ELISA IgM. Of the total initial sera, 334 (sensitivity 91.8\%) were positive in the CHT, 332 (sensitivity $91.2 \%$ ) in the MAT, 330 (sensitivity 90.7\%) in the ICT, and 328 (sensitivity 90.1\%) in the ELISA IgG and ELISA IgM tests. The specificity of the CHT was $96.7 \%$; of the MAT, 100\%; of the ICT, $98.7 \%$; and of the ELISA IgG and ELISA IgM, $97.4 \%$. In the group of patients with serology positive to Brucella, at least $12.4 \%$ of sera were positive in tularemia tests (12.4\% in ELISA IgM, $13.4 \%$ in MAT, $14.4 \%$ in ICT, and $15.5 \%$ in CHT and ELISA IgG). In conclusion, CHT presents a sensitivity and specificity in early diagnosis of human tularemia, similar to MAT, ICT, and ELISA IgG and ELISA IgM. Its single assay design allows lower costs, especially in areas of low endemicity or inter-epidemic periods.
\end{abstract}

\section{Introduction}

Tularemia is a zoonosis endemic in certain areas of the northern hemisphere. It is caused by Francisella tularensis, facultative intracellular gram negative coccobacillus. Four subspecies have been described (F. tularensis subsp. tularensis, F. tularensis subsp. holarctica, F. tularensis subsp.

Gabriel A. March

gmr810@ hotmail.com

1 Department of Microbiology, Faculty of Medicine, University of Valladolid, Valladolid, Spain

2 Department of Microbiology, University of Salamanca, Salamanca, Spain

3 Faculty of Nursery, University of Valladolid, Valladolid, Spain

4 Service of Microbiology, Hospital Clínico Universitario, Ramón y Cajal avenue, Number 3, 47003 Valladolid, Spain mediasiatica, and F. tularensis subsp. novicida), but only F. tularensis subsp. tularensis and F. tularensis subsp. holarctica are of epidemiological importance as agents causing human disease. F. tularensis subsp. tularensis is principally found in North America and, to a lesser extent, in Europe. In contrast, F. tularensis subsp. holarctica is basically distributed throughout Europe and Asia and less often found in North America [1]. Although human tularemia normally presents as sporadic cases, important epidemic outbreaks have recently occurred in various countries. In Finland, outbreaks of human tularemia have appeared every 3 or 4 years, with a maximum incidence of around 18/100,000 inhabitants in 2000 [2]. Similar outbreaks appeared in Sweden in 2000, 2003, and 2012 [3], in France in 2008 [4], and in Turkey [5]. Spain has seen two important outbreaks produced by $F$. tularensis subs. Holartica over the last few years. The first was in 19971998 , with 604 cases [6, 7], and the second, in 2007-2008, with 507 confirmed cases [8].

F. tularensis can be transmitted to humans by direct contact with infected animals, inhalation of contaminated aerosols or 
farm dust, bites by infective arthropods, and by ingestion of contaminated water or food [9]. The reservoir consists of more than 200 animal species, including rabbits, hares, and small rodents. The facts that the bacteria can produce serious diseases in humans, that it has a very low infectious dose (10-50 bacteria), and that it can use multiple transmission mechanisms make $F$. tularensis a class 3 biological risk agent of potential use as a terrorist weapon in biological warfare [9].

Patients usually present with at least one of six classic clinical forms: ulceroglandular, glandular, oculoglandular, pneumonic, typhoidal, and pharyngeal. Although it is principally diagnosed on a clinical basis, confirmation requires microbiological diagnosis, especially in the pneumonic, typhoidal, and pharyngeal forms [10]. Laboratory diagnosis is essentially based on the culture or determination of F. tularensis-specific antibodies. Other techniques such as PCR using clinical samples are moderately sensitive, the percentage varying depending on technical methods and sample types [11]. Culturing is difficult because the bacteria grow slowly and need enriched media to develop, making the percentage of isolation low. Risk of accidental contamination among laboratory staff is also very high $[1,12]$. These difficulties have led to diagnosing human tularemia based mainly on the clinical picture and serology $[1,13]$. However, serology poses important problems of interpretation due to the facts that antibodies to $F$. tularensis remain elevated for years after the disease is cured and that there are cross reactions with other bacterial groups, such as bacteria of the genus Brucella [14-16]. To date, several serological methods for the diagnosis of human tularemia have been described, the most used being agglutination assays and enzyme-linked immunosorbent assays (ELISA).

The objectives of this study were to ascertain the usefulness of a new single-assay format chemiluminescence test (CHT) for the diagnosis of human tularemia (Tularaemia VIRCLIA IgG + IgM monotest, Vircell, Santa Fe, Granada, Spain) and to compare it with well-established human tularemia diagnostic assays such as the commercial assay microagglutination test, ELISA IgG and ELISA IgM assays, and immunochromatographic lateral flow test (ICT) (Virapid Tularaemia, Vircell, Santa Fe, Granada, Spain).

\section{Materials and methods}

\section{Clinical material}

A total of 773 sera from 773 patients belonging to different groups were studied (Table 1). All the sera came from aliquots stored at $-40{ }^{\circ} \mathrm{C}$ in the sera collection in the Valladolid Regional Reference Laboratory on Brucellosis at the University of Valladolid (Spain). All sera were tested by microagglutination test (MAT), immunochromatographic lateral flow test (ICT) (Virapid Tularaemia, Vircell), ELISA IgG, ELISA IgM, and the new single-assay chemiluminescence test (CHT) (Tularaemia VIRCLIA IgG + IgM monotest, Vircell).

The first group consisted of 364 sera from 364 patients with diagnosed tularemia from the 1997-1998 outbreak in the Castilla y León Region (Spain) [7]. All these sera (henceforth called initial sera) were obtained at the time the patients came for the first consultation, in which tularemia was suspected and later confirmed. Of the 364 patients, $76(20.8 \%)$ were female, with a mean age of $52.9 \pm$ 14.5 years, and 288 were male, with a mean age of $51.9 \pm$ 15.6 years. In agreement with the WHO case definition [1], tularemia diagnosis was clinically suspected and was confirmed by isolation of $F$. tularensis in blood culture (5 cases) or ulcer exudate ( 2 cases), seroconversion when the initial sera were negative in the microagglutination test, or an increase of four times the microagglutination titer between the initial serum and a second serum taken between 10 and 20 days later [7, 10, 13].

The second serum group constituted the negative control group. It consisted of the sera from 152 individuals living in the same villages and geographical area in which the 19971998 tularemia outbreak appeared. These 152 sera came from samples of 4,825 sera from healthy individuals randomly selected from a seroepidemiological study on zoonosis carried out in the Castilla y León Region (Spain) between April 1996 and April 1997 [17]. Mean age was $50.0 \pm 14.0$ years (males, $49.0 \pm 14.3$; females, $52.0 \pm 13.0$ ). None of these people presented a clinical picture or suspicion of tularemia.

The third group of sera from 1997 and 1998 corresponded to 100 patients that came to medical consultation with suspected tularemia in which the disease was not confirmed. None of them had a history of tularemia. This patient group came from the same geographical area as the group of patients with tularemia.

To study possible cross-reactions with other processes, 97 sera from patients with serology positive to Brucella were included. Of these, 66 presented acute brucellosis, four presented as a recurrence of treated brucellosis, and 27 patients had had brucellosis within the previous 24 months but were currently brucellosis-free. In addition, 30 patients diagnosed with other infectious diseases and 30 patients diagnosed with autoimmune diseases were included in the study (Table 1). Similarly, none of them had a history of tularemia.

\section{Methods}

\section{Microagglutination test (MAT)}

An in-house microagglutination test (MAT) was performed following the previously described technique [18]. 
Table 1 Distribution of the 773 study patients

\begin{tabular}{|c|c|c|}
\hline Distribution of patients & Type & $\begin{array}{l}\text { Number of } \\
\text { patients, } n\end{array}$ \\
\hline \multirow[t]{8}{*}{ Patients with tularemia } & All types & 364 \\
\hline & Glandular tularemia & 47 \\
\hline & Pneumonic tularemia & 28 \\
\hline & Oculoglandular tularemia & 5 \\
\hline & Oropharyngeal tularemia & 12 \\
\hline & Typhoidal tularemia & 55 \\
\hline & Ulceroglandular tularemia & 211 \\
\hline & Clinical form not specified & 6 \\
\hline \multicolumn{2}{|c|}{ Patients with unconfirmed but suspected tularemia } & 100 \\
\hline \multicolumn{2}{|l|}{ Negative control group } & 152 \\
\hline \multicolumn{2}{|c|}{ Patients with serology positive for Brucella ${ }^{\mathrm{a}}$} & 97 \\
\hline \multirow[t]{4}{*}{ Patients with other infections } & Gastroenteritis from Salmonella spp. & 6 \\
\hline & Typhoid fever & 2 \\
\hline & Helicobacter pylori & 7 \\
\hline & Toxoplasma gondii & 15 \\
\hline \multirow[t]{8}{*}{ Autoimmune diseases } & Rheumatoid arthritis & 7 \\
\hline & Systemic lupus erythematosus & 6 \\
\hline & Autoimmune hepatitis & 3 \\
\hline & Primary biliary cirrhosis & 3 \\
\hline & Atrophic gastritis & 4 \\
\hline & Sjögren's Syndrome & 4 \\
\hline & Scleroderma & 2 \\
\hline & $\begin{array}{l}\text { Antineutrophil cytoplasmic antibody } \\
\text { (ANCA)-associated vasculitis }\end{array}$ & 1 \\
\hline
\end{tabular}

${ }^{a} 66$ patients with acute brucellosis, 4 patients with recurrence of treated brucellosis, and 27 patients seen and treated within the previous 24 months and currently cured

\section{ELISA IgG and ELISA IgM assay}

The in-house ELISA tests were designed to detect IgG and IgM anti-LPS F. tularensis antibodies. LPS was extracted by Westphal and Jann's hot phenol-water method modified for F. tularensis [19]. The ELISA techniques were performed following the procedure described by Porsch-Ozcurumez et al. [20].

\section{Immunochromatographic lateral flow test (ICT) and chemiluminescence test (CHT)}

To detect anti-LPS F. tularensis antibodies, a commerciallyavailable immunochromatographic lateral flow test (ICT) (Virapid Tularaemia, Vircell) and a single-assay chemiluminescence test (CHT) (Tularaemia VIRCLIA IgG + IgM monotest, Vircell) were obtained from the manufacturer and were used according to the manufacturer's instructions.

\section{Statistical analysis}

Data were analyzed with the help of SPSS 24 and EPIDAT 3.1 programs. The CHT results were compared with those from the MAT, ELISA IgG, ELISA IgM, and ICT in all 773 sera studied. Sensitivity, specificity, and likelihood ratio (LR) for positive and negative results were calculated in every study. The $95 \%$ confidence intervals (CI) were calculated for sensitivity, specificity, and LR. The sensitivity and specificity results obtained with MAT, CHT, ELISA IgG, and ELISA IgM for different cutoff points were graphically represented by a diagnostic efficiency curve (receiver operating characteristic curve or ROC curve). The area under the curve was calculated with a corresponding $\mathrm{CI}$.

\section{Results}

Of the 364 initial sera from patients with tularemia, 319 sera $(87.7 \%)$ showed positive in the five tests, 18 sera $(4.9 \%)$ were negative in all the tests, and $45(12.4 \%)$ showed negative in one or more tests. The CHT, MAT, ICT, and ELISA IgG were the only tests positive in 2, 1, 5, and 3 cases, respectively. All the tests that were negative with the initial serum were positive with the sera from the same patient taken 10-20 days later (data not shown). 
Of the total initial sera, 334 (sensitivity $91.8 \%$ ) were positive in the CHT, 332 (sensitivity $91.2 \%$ ) in the MAT, 330 (sensitivity $90.7 \%$ ) in the ICT, and 328 (sensitivity $90.1 \%$ ) in the ELISA IgG and ELISA IgM tests (Table 2). No statistically significant differences were seen in the percentage of seropositivity for each test based on age, sex, or tularemia clinical presentation form.

In the negative control group, the CHT was positive in 5 sera (specificity $96.7 \%$ ), the MAT was negative in all sera, the ICT was positive in 2 sera (specificity $98.7 \%$ ), and the ELISA IgG and ELISA IgM were positive in 4 sera (specificity $97.4 \%$ ) (Table 2). The positive LR values were above 10 in all tests and the negative LR values were lower than 0.1 in all tests (Table 2).

The diagnostic efficiency of the tests against $F$. tularensis was analyzed in our study (Fig. 1). The area below the ROC curve for the CHT was 0.953 (95\% CI, 0.935-0.971); for the MAT, it was 0.956 (95\% CI, 0.939-0.974); and for the ELISA IgM and for the ELISA IgG, it was 0.970 (95\% CI, 0.954 0.986).

In the group of patients with unconfirmed but suspected tularemia, the CHT was positive in five samples (specificity 95\%), ELISA IgG was positive in eight samples (specificity 92\%), and ELISA IgM was positive in four (specificity 96\%), while the MAT and ICT tests were negative in all sera (Table 3).

Of the 30 patients with other infections, only one (with typhoid fever) was positive in all the tests except the MAT. Of the 30 patients with autoimmune diseases, only one patient with rheumatoid arthritis (positive antinuclear antibodies) was positive in all the tests except the MAT (Table 3).

Of the 97 sera with serology positive for Brucella, 15 $(15.5 \%)$ patients were positive for F. tularensis in one or more serological tests (Table 4). The ELISA IgM test returned the least number of $F$. tularensis-positive sera, with $12.4 \%$ positive sera. Next, in descending order, were the MAT (13.4\%), ICT (14.4\%), and ELISA IgG and CHT, both with $15.5 \%$. Of the 66 patients with acute brucellosis, $12(18.2 \%)$ presented positive results in some of the $F$. tularensis tests. Of these, 9 $(13.6 \%)$ were positive in all the tests against $F$. tularensis. Of the remaining three, one patient $(1.5 \%)$ was negative in the
MAT, one patient $(1.5 \%)$ in the ELISA IgM test, and one patient $(1.5 \%)$ in the ICT. Of the four patients with brucellosis recurrence from therapy failure, one was positive in all tests against $F$. tularensis. Of the 27 patients with brucellosis treated and cured in the previous 24 months, 2 (7.4\%) were positive in the ICT, ELISA IgG, and CHT, one of whom was also positive in the MAT. None of the sera with titers lower than 1/80 in the Coombs anti-Brucella test was positive in any of the serological tests against $F$. tularensis. The higher the titers obtained in the Coombs anti-Brucella test were, the higher the percentage of seropositivity in all the tests against $F$. tularensis was; however, there were no statistically significant differences (Table 4).

\section{Discussion}

The CHT used in our study showed good sensitivity (91.8\%) for diagnosing human tularemia, similar to the rest of the study serological tests (ranging from $90.1 \%$ in the ELISA IgG assay to $91.2 \%$ in the MAT). This sensitivity is slightly lower than that found by other authors, who reported sensitivity higher than $94 \%$ in all the tests studied $[15,21]$. The differences between our study results and those of other authors can be explained by the fact that most authors [15, 16, 21] used one or more serum samples from each patient taken at different times in the disease evolution, when the immune response had consequently already been established. However, our study included only the initial sera, taken when the patients came for medical consultation the first time. It should be remembered that the 1997-1998 tularemia outbreak was the first recognized outbreak in Spain. Consequently, the concern created in the population in the villages affected caused many patients in our study to come to the primary care surgery before 7 days after fever or any other symptoms appeared. That is why $18(4.9 \%)$ of the initial sera in our study were negative in all tests, and $45(12.4 \%)$ showed negative in one or more tests. Kiliç et al. [16] found that only $20 \%$ of the sera obtained within the first 7 days after disease onset were positive in MAT and immunochromatographic tests.

Table 2 Sensitivity, specificity, predictive value, and likelihood ratio (LR) of the MAT, ICT, ELISA IgG, ELISA IgM, and CHT in the 364 initial sera from tularemia patients and 152 sera from healthy people

\begin{tabular}{|c|c|c|c|c|c|c|}
\hline Test & Sensitivity $^{\mathrm{a}}$ & Specificity $^{\mathrm{a}}$ & Positive predictive value ${ }^{a}$ & Negative predictive value ${ }^{a}$ & Positive LR & Negative LR \\
\hline CHT & $91.8 \%(88.8-94.7)$ & $96.7 \%(92.6-99.5)$ & $98.2(96.7-99.8)$ & $82.9(77.1-88.8)$ & $23.3(10.6-50.9)$ & $0.09(0.06-0.12)$ \\
\hline MAT & $91.2 \%(88.2-94.3)$ & $100 \%(99.7-100)$ & $100(99.8-100)$ & $82.6(76.9-88.4)$ & $\infty$ & $0.09(0.06-0.12)$ \\
\hline ICT & $90.7 \%(87.5-93.8)$ & $98.7 \%(96.5-100)$ & $99.4(98.4-100)$ & $81.5(75.6-87.4)$ & $68.9(17.4-273.1)$ & $0.90(0.07-0.13)$ \\
\hline ELISA IgG & $90.1 \%(86.9-93.3)$ & $97.4 \%(94.5-100)$ & $98.8(97.5-100)$ & $80.4(74.4-86.4)$ & $34.2(13.0-90.1 .9)$ & $0.10(00.7-0.14)$ \\
\hline ELISA IgM & $90.1 \%(86.9-93.3)$ & $97.4 \%(94.5-100)$ & $98.8(97.5-100)$ & $80.4(74.4-86.4)$ & $34.2(13.0-90.1 .9)$ & $0.10(00.7-0.14)$ \\
\hline
\end{tabular}

${ }^{\text {a }}$ Values are given as percentage with the value in parentheses indicating the $95 \%$ confidence interval 

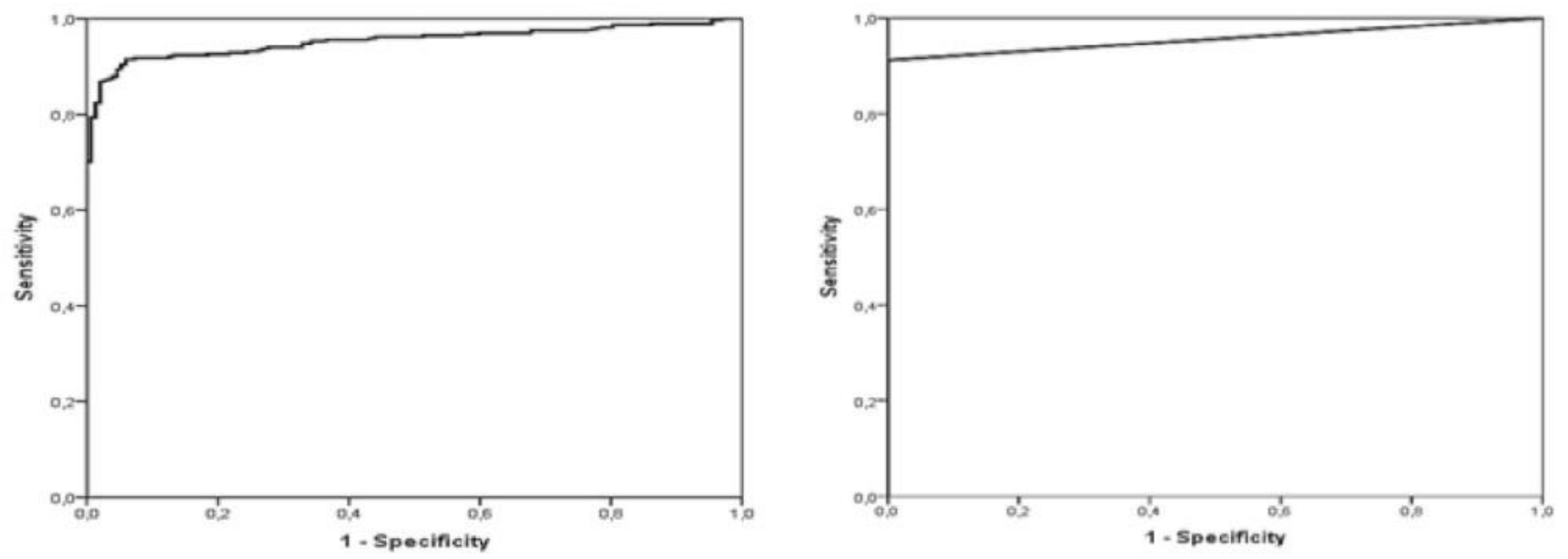

$\mathrm{CHT}$

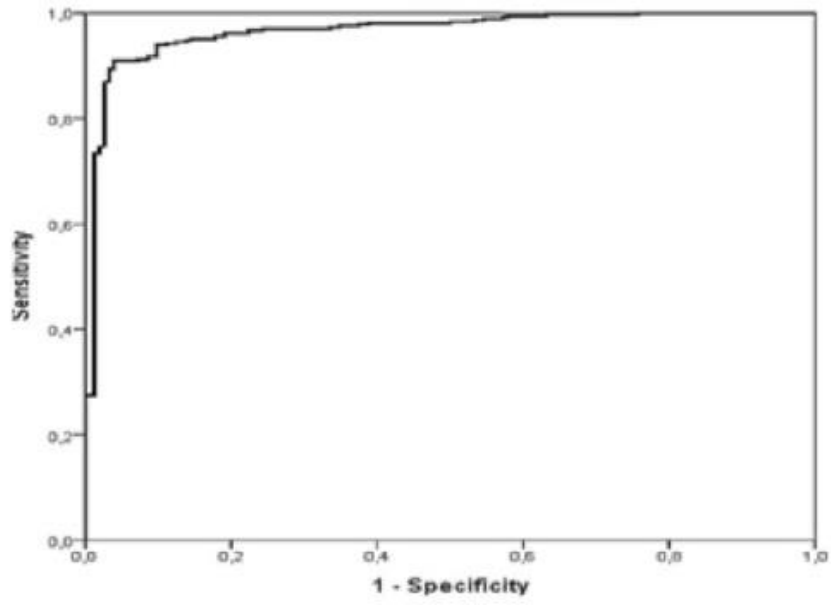

MAT

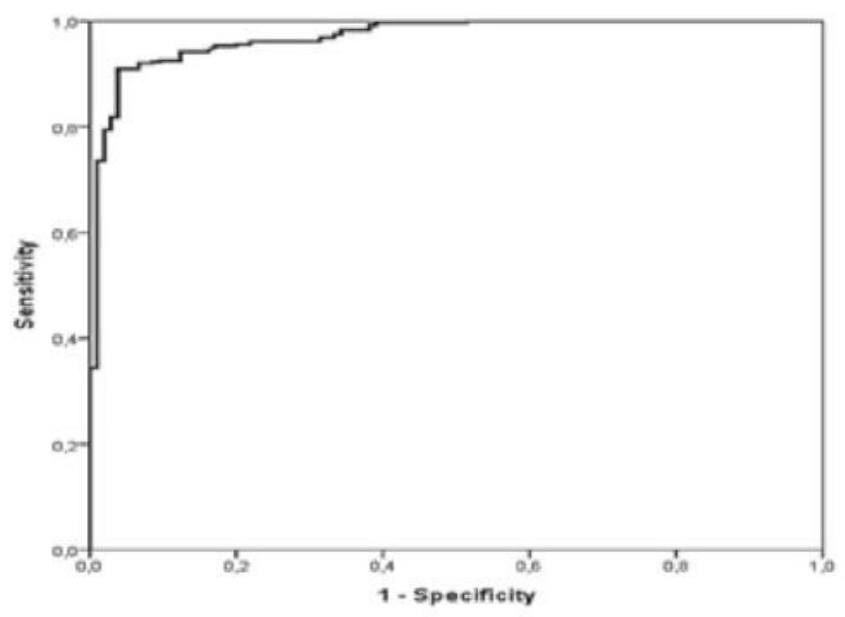

\section{ELISA IgM}

ELISA IgG

Fig. 1 Diagnostic efficiency curves (ROC curves) for the CHT, MAT, ELISA IgM, and ELISA IgG. Area below the ROC curve: CHT, 0.953 ( $95 \%$ CI, 0.935-0.971); MAT, 0.956 (95\% CI, 0.939-0.974); ELISA IgM, 0.970 (95\% CI, 0.954-0.986); ELISA IgG, 0.970 (95\% CI, 0.954-0.986)

However, after 14 days from symptom appearance, the percentage of positive sera rose to $82 \%$.

Techniques such as ELISA are good tools for diagnosing human tularemia, especially during epidemics and in seroepidemiological studies when the number of sera to analyze is elevated $[20,22]$. However, in periods between epidemics, when tularemia appears as sporadic cases, ELISA tests are expensive because of how long they take to perform and the fact that three or four controls reaction wells (positive, negative, quality control and cut-off sera) and the patient sera reaction well are needed to be included for one serum sample assay (Table 5). In contrast, the single-assay
Table 3 Specificity to sera from 100 patients with unconfirmed but suspected tularemia, 97 patients with brucellosis or serology positive for Brucella, 30 patients with other infections, and 30 patients with autoimmune diseases

\begin{tabular}{lllll}
\hline Test & $\begin{array}{l}\text { Patients with unconfirmed } \\
\text { but suspected tularemia }\end{array}$ & $\begin{array}{l}\text { Patients with brucellosis }_{\text {or serology positive for }} \\
\text { Brucella }^{\mathrm{a}}\end{array}$ & Other infections $^{\mathrm{a}}$ & $\begin{array}{l}\text { Autoimmune } \\
\text { diseases }^{\mathrm{a}}\end{array}$ \\
\hline CHT & $5(95.0 \%)$ & $15(84.5 \%)$ & $1(96.7 \%)$ & $1(96.7 \%)$ \\
MAT & $0(100 \%)$ & $13(86.6 \%)$ & $0(100 \%)$ & $0(100 \%)$ \\
ICT & $0(100 \%)$ & $14(85.6 \%)$ & $1(96.7 \%)$ & $1(96.7 \%)$ \\
ELISA IgG & $8(92.0 \%)$ & $15(84.5 \%)$ & $1(96.7 \%)$ & $1(96.7 \%)$ \\
ELISA IgM & $4(96.0 \%)$ & $12(87.6 \%)$ & $1(96.7 \%)$ & $1(96.7 \%)$ \\
\hline
\end{tabular}

aNo. of tularemia positive sera (specificity) 
Table 4 Relationship between the Coombs anti-Brucella test titers and the results of the serological F. tularensis tests in the 97 patients seropositive for Brucella

\begin{tabular}{|c|c|c|c|c|c|c|c|c|c|c|}
\hline \multirow[t]{2}{*}{ Coombs anti-Brucella test } & \multicolumn{2}{|l|}{$\mathrm{CHT}^{\mathrm{a}}$} & \multicolumn{2}{|l|}{ MAT $^{a}$} & \multicolumn{2}{|l|}{$\mathrm{ICT}^{\mathrm{a}}$} & \multicolumn{2}{|l|}{ ELISA IgG ${ }^{\mathrm{a}}$} & \multicolumn{2}{|l|}{ ELISA IgM ${ }^{a}$} \\
\hline & Positive & Negative & Positive & Negative & Positive & Negative & Positive & Negative & Positive & Negative \\
\hline $1 / 80$ & $2(15 \%)$ & 11 & $1(7.7 \%)$ & 12 & $2(15 \%)$ & 11 & $2(15 \%)$ & 11 & 0 & 13 \\
\hline $1 / 160$ & $2(13 \%)$ & 13 & $2(13.3 \%)$ & 13 & $2(13 \%)$ & 13 & $2(13 \%)$ & 13 & $1(6 \%)$ & 14 \\
\hline $1 / 320$ & $4(17 \%)$ & 19 & $3(13.0 \%)$ & 20 & $3(13 \%)$ & 20 & $4(17 \%)$ & 19 & $4(17 \%)$ & 19 \\
\hline $1 / 640$ & $3(23 \%)$ & 10 & $3(23.1 \%)$ & 10 & $3(23 \%)$ & 10 & $3(23 \%)$ & 10 & $3(23 \%)$ & 10 \\
\hline $1 / 1280$ & $4(19 \%)$ & 17 & $4(19.0 \%)$ & 17 & $4(19 \%)$ & 17 & $4(19 \%)$ & 17 & $4(19 \%)$ & 17 \\
\hline$P$ value $<1 / 80-\geq 1 / 80$ & 0.391 & & 0.231 & & 0.392 & & 0.391 & & 0.115 & \\
\hline Total & $15(15.5 \%)$ & 82 & $13(13.4 \%)$ & 84 & $14(14.4 \%)$ & 83 & $15(15.5 \%)$ & 82 & $12(12.4 \%)$ & 85 \\
\hline
\end{tabular}

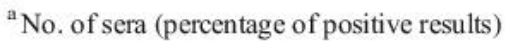

9/66 (13.6\%) patients with acute brucellosis positive to MAT, ICT, ELISA IgG, ELISA IgM, and CHT;

$1 / 66(1.5 \%)$ patients with acute brucellosis positive to MAT, ICT, ELISA IgG, and CHT;

$1 / 66(1.5 \%)$ patients with acute brucellosis positive to MAT, ELISA IgG, ELISA IgM, and CHT;

$1 / 66(1.5 \%)$ patients with acute brucellosis positive to ICT, ELISA IgG, ELISA IgM, and CHT;

$1 / 4$ patient with brucellosis recurrence positive to MAT, ICT, ELISA IgG, ELISA IgM, and CHT;

$2 / 27(7.4 \%)$ patients with brucellosis treated and cured in the previous 24 months, ICT, ELISA IgG, and CHT, positive; 1 MAT positive as well

CHT only needs one sample reaction unit because the design itself makes control sera unnecessary, allowing sera to be analyzed individually $[16,21]$.

Another interesting aspect of our study was the analysis of whether there were differences in serological test sensitivity depending on the clinical presentation of the disease. However, no statistically significant differences were found in any of the cases. Besides, CHT specificity was similar to that from the rest of the tests; it was also always above $95 \%$ when we used the negative control group (healthy individuals from the tularemia-affected area) and in the control group (patients with unconfirmed but suspected tularemia). However, the specificity of the tests decreased greatly for patients with Brucella-positive serology. In our study, the percentage of positives against tularemia in healthy individuals with a history of brucellosis and antibodies against Brucella (7.4\%) was similar to that found by other authors [16]. In contrast, the percentage of patients with acute brucellosis that presented serology positive against $F$. tularensis was much higher $(18.2 \%)$. In addition, the positivity in the serological tests against $F$. tularensis occurred in sera with mid-level titers and high titers in the Coombs anti-Brucella test (10 sera, $9.7 \%$, with titers $\geq 1 / 320$ ), potentially diagnostic of brucellosis.

Human tularemia often (especially in the typhoid forms) presents with non-specific symptoms, requiring a differential diagnosis with other infectious diseases [10]. The fact that sera from patients with other infectious processes, such as brucellosis, present cross-reactions with $F$. tularensis [14, 23] causes a diagnostic problem that is especially relevant in rural areas where brucellosis is endemic.

In conclusion, the single-assay chemiluminescence test presents good sensitivity and specificity in early serological diagnosis of human tularemia, similar to that shown by microagglutination, immunochromatographic lateral flow, ELISA IgG, and ELISA IgM tests. Its design makes individual use possible, lowering assay cost and making it especially

Table 5 Comparative study of test costs between ELISA and CHT monotest for serological diagnosis of human tularemia

\begin{tabular}{lllllll}
\hline Test & Manufacturer & $\begin{array}{l}\text { No. controls } \\
\text { and cut-off }\end{array}$ & Cost per kit & $\begin{array}{l}\text { Cost per } \\
\text { well }\end{array}$ & $\begin{array}{l}\text { Cost of controls } \\
\text { and cutoff }\end{array}$ & $\begin{array}{l}\text { Cost per } \\
\text { one patient } \\
\text { sample }\end{array}$ \\
\hline $\begin{array}{l}\text { Serazym Anti-Francisella tularensis } \\
\text { GAM (ELISA) }\end{array}$ & Seramun Diagnostica GmbH & 3 & $450 € / 96$ wells & $4.68 €$ & $14.87 €$ & $19.83 €$ \\
$\begin{array}{l}\text { Francisella tularensis IgG (ELISA) } \\
\text { Tularemia IgG (ELISA) }\end{array}$ & IBL America & 2 & $423 € / 96$ wells & $4.40 €$ & $8.80 €$ & $13.2 €$ \\
Francisella tularensis IgG (ELISA) & CD creative diagnostics & 4 & $835 € / 96$ wells & $8.70 €$ & $34.79 €$ & $43.49 €$ \\
Tularemia VirClia G +M (CHT) & Vircell S.A. & 4 & $655 / 96$ wells & $6.82 €$ & $27.29 €$ & $34.11 €$ \\
\hline
\end{tabular}


useful when it is necessary to study 1 or 2 sera, as is the case in areas where endemicity is low and in periods between epidemics.

Acknowledgements The authors wish to thank Prof. C. Nolan for collaborating with revising the English version.

Funding This research received no specific grant from any funding agency in the public, commercial, or not-for-profit sectors.

\section{Compliance with ethical standards}

Conflicts of interest We declare no conflicts of interest.

Ethical approval and informed consent Written informed consent was taken by the participants and the study was approved by the Ethics Committee of the Valladolid Clinic University Hospital and the Faculty of Medicine of the University of Valladolid (reference CEIC-PI-16-478). All sera were anonymized in relation to patient data.

\section{References}

1. WHO (2007) WHO Guidelines on Tularaemia: epidemic and pandemic alert response. WHO Press, Geneva http://www.who.int/csr/ resources/publications/WHO CDS_EPR 2007 7.pdf

2. Rossow H, Ollgren J, Hytonen J, Rissanen H, Huitu O, Henttonen $\mathrm{H}$, Kuusi M, Vapalahti O (2015) Incidence and seroprevalence of tularaemia in Finland, 1995 to 2013: regional epidemics with cyclic pattem. Euro Surveill 20(33):21209

3. Desvars A, Furberg M, Hjertqvist M, Vidman L, Sjöstedt A, Rydén P, Johansson A (2015) Epidemiology and Ecology of Tularemia in Sweden, 1984-2012. Emerg Infect Dis J 21(1):32

4. Mailles A, Vaillant V (2014) 10 years of surveillance of human tularaemia in France. Euro Surveill 19(45):20956

5. Akalin H, Helvaci S, Gedikoglu S (2009) Re-emergence of tularemia in Turkey. Int J Infect Dis 13(5):547-551

6. Ariza-Miguel J, Johansson A, Fernandez-Natal MI, Martinez-Nistal C, Orduna A, Rodriguez-Ferri EF, Hernandez M, RodriguezLazaro D (2014) Molecular investigation of tularemia outbreaks, Spain, 1997-2008. Emerg Infect Dis 20(5):754-761

7. Centro Nacional de Epidemiología (Instituto de Salud Carlos III) (1997) Brote de tularemia en Castilla y León. BES 5:249-252

8. Consejería de Sanidad (Junta de Castilla y León Spain) (2007) Informe sobre la situación epidemiológica de los casos de tularemia en Castilla y León. Año 2007 Consejería de Sanidad de la Junta de Castilla y León (Spain), Valladolid, Spain.http://www. saludcastillayleon.es/ciudadanos/es/enfermedades-problemassalud/tularemia/vigilancia-epidemiologica-tularemia-castillaleon 2011

9. Dennis DT, Inglesby TV, Henderson DA, Bartlett JG, Ascher MS, Eitzen E, Fine AD, Friedlander AM, Hauer J, Layton M, Lillibridge SR, JE MD, Osterholm MT, O'Toole T, Parker G, Perl TM, Russell
PK, Tonat K, for the Working Group on Civilian B (2001) Tularemia as a biological weapon: medical and public health management. JAMA 285(21):2763-2773

10. Penn RL (2015) Francisella tularensis (Tularemia). In: Mandell GL, Bennett JE, Dolin R (eds) Principles and practice of infectious diseases. Elsevier, Churchill Livingstone, Philadelphia, pp 2590-2602

11. Willke A, Meric M, Grunow R, Sayan M, Finke EJ, Splettstosser W, Seibold E, Erdogan S, Ergonul O, Yumuk Z, Gedikoglu S (2009) An outbreak of oropharyngeal tularaemia linked to natural spring water. J Med Microbiol 58(Pt 1):112-116

12. Ellis J, Oyston PCF, Green M, Titball RW (2002) Tularemia. Clin Microbiol Rev 15(4):631-646

13. Centers for Disease Control and Prevention (1997) Case definitions for infectious conditions under public health surveillance. MMWR 46:(No. RR-10)

14. Francis E, Evans AC (1926) Agglutination, cross-agglutination, and agglutinin absorption in tularemia. Public Health Rep 41: 1273-1290

15. Chaignat V, Djordjevic-Spasic M, Ruettger A, Otto P, Klimpel D, Muller W, Sachse K, Araj G, Diller R, Tomaso H (2014) Performance of seven serological assays for diagnosing tularemia. BMC Infect Dis 14:234

16. Kiliç S, Celebi B, Yesilyurt M (2012) Evaluation of a commercial immunochromatographic assay for the serologic diagnosis of tularemia. Diagn Microbiol Infect Dis 74(1):1-5

17. Garrote JI, Gutierrez MP, Izquierdo RL, Duenas MA, Zarzosa P, Canavate C, El Bali M, Almaraz A, Bratos MA, Berbel C, Rodriguez-Torres A, Domingo AO (2004) Seroepidemiologic study of Leishmania infantum infection in Castilla-Leon, Spain. Am J Trop Med Hyg 71(4):403-406

18. Brown SL, McKinney FT, Klein GC, Jones WL (1980) Evaluation of a safranin-O-stained antigen microagglutination test for francisella tularensis antibodies. J Clin Microbiol 11(2):146-148

19. Sandstrom G, Sjostedt A, Johansson T, Kuoppa K, Williams JC (1992) Immunogenicity and toxicity of lipopolysaccharide from Francisella tularensis LVS. FEMS Microbiol Immunol 5(4): 201-210

20. Porsch-Ozcurumez M, Kischel N, Priebe H, Splettstosser W, Finke E-J, Grunow R (2004) Comparison of enzyme-linked immunosorbent assay, Western blotting, microagglutination, indirect immunofluorescence assay, and flow cytometry for serological diagnosis of tularemia. Clin Diagn Lab Immunol 11(6): 1008-1015

21. Splettstoesser W, Guglielmo-Viret V, Seibold E, Thullier P (2010) Evaluation of an immunochromatographic test for rapid and reliable serodiagnosis of human tularemia and detection of Francisella tularensis-specific antibodies in sera from different mammalian species. J Clin Microbiol 48(5):1629-1634

22. Schmitt P, Splettstosser W, Porsch-Ozcurumez M, Finke EJ, Grunow R (2005) A novel screening ELISA and a confirmatory Western blot useful for diagnosis and epidemiological studies of tularemia. Epidemiol Infect 133(4):759-766

23. Bevanger L, Maeland JA, Naess AI (1988) Agglutinins and antibodies to Francisella tularensis outer membrane antigens in the early diagnosis of disease during an outbreak of tularemia. J Clin Microbiol 26(3):433-437 


\section{Enfermedades}

Infecciosas

Microbiología

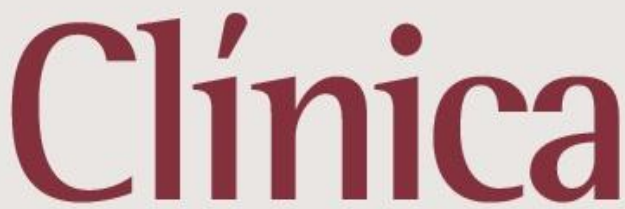

Volumen 35, Especial Congreso 1, Mayo 2017 Publicación mensual

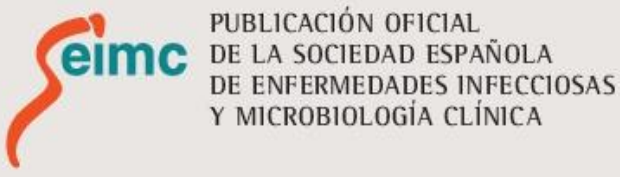

XXI Congreso de la Sociedad Española de Enfermedades Infecciosas y Microbiología Clínica (SEIMC)

Málaga, 11-13 de mayo de 2017

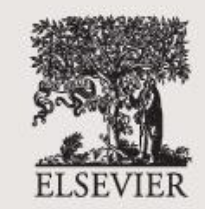

www.elsevier.es/eimc
Incluida en: Index Medicus/MEDLINE Excerpta Medica/EMBASE

Current Contents/Clinical Medicine ISI Alerting Services

Science Citation Index-Expanded Journal Citation Reports SCOPUS

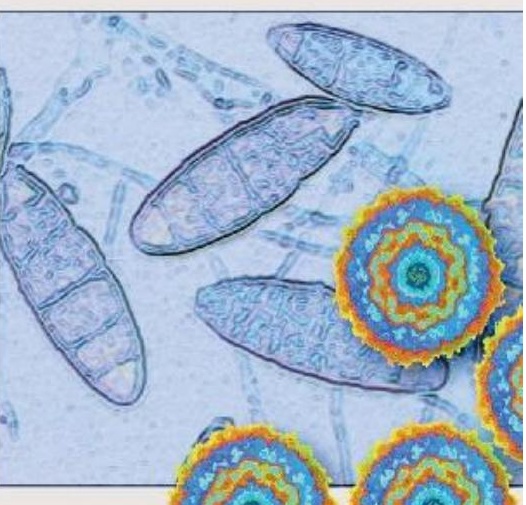

4 (20)
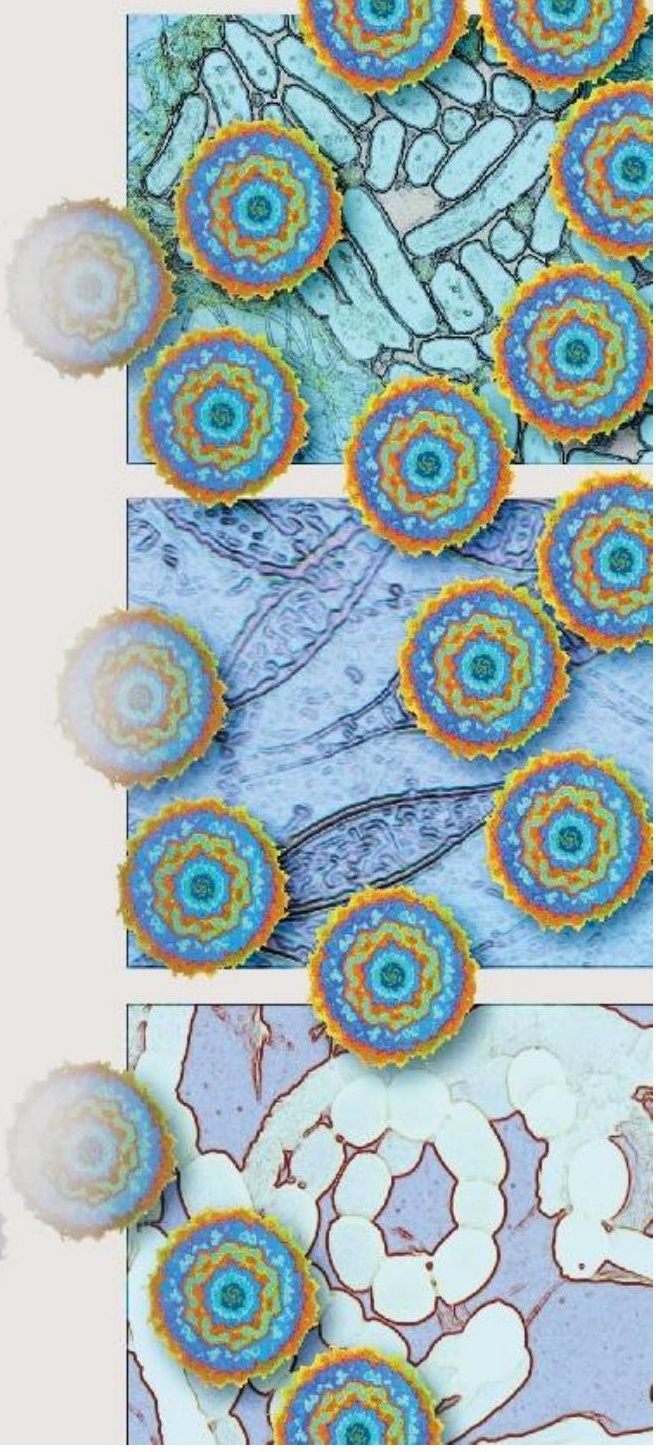
Tabla. Comunicación 779

Resultados del antibiograma por ambas técnicas

\begin{tabular}{|c|c|c|c|c|c|}
\hline Antibiótico/Técnica & Rango & CMI 50 & CMI 90 & Sensibilidad (n, \%) & Kappa \\
\hline \multicolumn{6}{|c|}{ Enterobacteriaceae $\mathrm{n}=216$ cepas } \\
\hline CAZ/TGA & $0,016->256$ & 0,25 & 48 & $187(86,6)$ & 92,2 \\
\hline CAZ/Microdilución & $<0,06->32$ & 0,25 & 32 & $187(86,6)$ & - \\
\hline CEFTO/TAZO/TGA & $0,023->256$ & 0,25 & 1,5 & $197(91,2)$ & 91,1 \\
\hline CEFTO/TAZO/Microdilución & $<0,06->32$ & 0,25 & 1 & $199(92,1)$ & - \\
\hline MER/TGA & $0,002->32$ & 0,032 & 0,125 & $209(96,8)$ & 100 \\
\hline MER/Microdilución & $<0,06->32$ & $<0,06$ & 1 & $209(96,8)$ & - \\
\hline DOR/TGA & $0,002->32$ & 0,064 & 0,25 & $209(96,8)$ & 100 \\
\hline DOR/Microdilución & $<0,06->32$ & $<0,06$ & 0,5 & $209(96,8)$ & - \\
\hline \multicolumn{6}{|c|}{ Pseudomonas aeruginos $a \mathrm{n}=138$ cepas } \\
\hline $\mathrm{CAZ} / \mathrm{TGA}$ & $0,064->256$ & 2 & 192 & $102(73,9)$ & 81,7 \\
\hline CAZ/Microdilución & $<0,06->32$ & 4 & $>32$ & $106(76,8)$ & - \\
\hline CEFTO/TAZO/TGA & $0,047-16$ & 0.5 & 1,5 & $135(97,8)$ & 85,4 \\
\hline CEFTO/TAZO/Microdilución & $<0,06->64$ & 0.5 & 4 & $134(97,1)$ & - \\
\hline MER/TGA & $0,023->32$ & 4 & $>32$ & $62(44,9)$ & 91,5 \\
\hline MER/Microdilución & $<0,06->32$ & 4 & $>32$ & $65(47,1)$ & - \\
\hline DOR/TGA & $0,004->32$ & 4 & $>32$ & $60(43,5)$ & 84,7 \\
\hline DOR/Microdilución & $<0,06->32$ & 4 & 32 & $65(47,1)$ & - \\
\hline
\end{tabular}

Resultados: Se aislaron 384 patógenos en 327 muestras: Enterobacteriaceae, 216; Pseudomonas aeruginosa, 138; bacilos Gram negativos no fermentadores (excluyendo Stenotrophomonas maltophilia), 30. La correlación entre ambas técnicas fue excelente (índice Kappa $>80 \%$ ) (tabla).

Conclusiones: El antibiograma con tiras de gradiente de ceftazidima, ceftolozano-tazobactam, meropenem y doripenem directamente en muestras de tracto respiratorio inferior proporciona resultados precisos y fiables en 24 horas. El índice Kappa entre ambas técnicas fue excelente.

Sesión P-19:

Enfermedades importadas y emergentes

\section{DINÁMICA DEL VIRUS ZIKA EN LOS FLUIDOS CORPORALES Y RIESGO DE TRANSMISIÓN SEXUAL EN UNA ZONA NO ENDÉMICA}

A. Sánchez Montalvá, D. Pou, E. Sulleiro, F. Salvador, C. Bocanegra, B. Treviño, A. Rando, N. Serre e I. Molina

Hospital Universitari Vall d'Hebron.

Introducción: El virus Zika (ZIKV) se ha extendido rápidamente por el continente americano, afectando a más de 50 países en menos de un año. La enfermedad se transmite por la picadura de un mosquito Aedes infectado. También se ha descrito la excreción del ZIKV en fluidos genitales, así como la transmisión por vía sexual.

Objetivos: El objetivo de nuestro estudio es evaluar la dinámica del ZIKV en fluidos corporales de paciente infectados a través de la detección del ARN del virus y determinar el riesgo de transmisión sexual en los contactos sexuales.

Material y métodos: Se realizó un estudio prospectivo en dos centros del Programa de Salud Internacional de ICS (PROSICS). Los pacientes con un diagnóstico por ZIKV realizaban un seguimiento clínica y recogida de saliva, sangre, orina y fluidos genitales cada 4 semanas hasta la negativización de todas las muestras. Se realizó un estudio de las parejas sexuales para detectar infecciones sexuales por ZIKV. Resultados: Se incluyeron un total de 11 viajeros con la infección por ZIKV y 3 parejas sexuales entre enero 2016 y diciembre 2016. El 54.5\% eran hombres. La edad mediana fue de 38 (RI 30-45) años. Los motivos de los viajes fueron "visiting friends and relatives" 6 pacientes y turismo 5 pacientes. La mediana de duración del viaje fue de 24 (RI 11-34) días. Las pruebas de laboratorio se realizaron de mediana a los 11 (RI 3-31) días después del inicio de los síntomas. Nueve de once pacientes se diagnosticaron mediante una IgM ZIKV positivo o la detección del ARN del ZIKV. Se realizaron un total de 61 determinación de PCR, 7 de ellas con resultado positivo. Se detectó el ZIKV en muestras de sangre, orina, semen y tracto vaginal. El 25\% de las mujeres tuvieron un resultado positivo en el frotis vaginal recogido dentro de los 45 días posteriores al inicio de los síntomas. El aclaramiento del ZIKV ocurrió durante los días 37 y 69 después del inicio de los síntomas. Un $20 \%$ de las muestras de semen detectaron ARN del ZIKV. En el caso de los hombres el aclaramiento del ZIKV ocurrió durante el día 23 y el 107 después del inicio de los síntomas. Todos los pacientes con PCR de ZIKV positiva tuvieron una IgG ZIKV positiva, mientras que no todos los pacientes con IgM del ZIKV positiva seroconvirtieron para IgG. Los pacientes que presentaron la IgG y la IgM del ZIKV negativa nunca tuvieron detección del ARN del ZIKV en ningún fluido. De los tres contactos sexuales que no habían viajado, los tres tuvieron resultados serológicos del ZIKV negativos.

Conclusiones: Nuestro estudio detectó el ZIKV en un 25\% y $20 \%$ de las mujeres y los hombres respectivamente. El tiempo de aclaramiento estuvo más allá del día 37 para las mujeres y del día 24 para los hombres. No encontramos transmisión sexual del ZIKV entre los contactos sexuales. Los algoritmos diagnósticos del ZIKV se tendría que actualizar para incluir la detección del ZIKV en los fluidos genitales.

\section{ESTUDIO COMPARATIVO DE LA UTILIDAD DE VIRCLIA-TULAREMIA FRENTE A 4 PRUEBAS SEROLÓGICAS PARA EL DIAGNÓSTICO DE LA TULAREMIA HUMANA}

A. Orduña Domingo ${ }^{1}$, C. Durantez ${ }^{2}$, A. Cubero ${ }^{2}$, M.P. Gutiérrez ${ }^{2}$, M.J. Castro ${ }^{3}$, G. March-Roselló4, I. López-Ramos ${ }^{4}$, M.A. Bratos ${ }^{1}$ y M. Simarro ${ }^{2}$

'Universidad de Valladolid-Hospital Clínico Universitario, Valladolid. ${ }^{2}$ Universidad de Valladolid, Valladolid. ${ }^{3}$ Facultad de Enfermería, Universidad de Valladolid, Valladolid. ${ }^{4}$ Servicio de Microbiología, Hospital Clínico Universitario, Valladolid.

Objetivos: Tularemia es una zoonosis endémica en varias regiones del hemisferio norte que se presenta en forma de brotes epidémicos de forma periódica y como casos esporádicos en los períodos interepidémicos. El objetivo de este estudio es conocer la utilidad de una prueba de quimioluminiscencia monotest comercial para el diagnóstico serológico de la tularemia humana.

Material y métodos: Se han utilizado 364 sueros obtenidos en la primera consulta de pacientes diagnosticados de tularemia (sueros iniciales), 152 sueros de donantes sanos, 100 sueros de pacientes con sospecha de tularemia no confirmada, 97 sueros de pacientes con serología positiva frente a Brucella, 30 sueros de pacientes con otras 
infecciones y 30 sueros de pacientes con enfermedades autoinmunes. Se han ensayado 5 pruebas serológicas (chemiluminiscence monotest comercial (VIRCLIA Tularemia IgG+IgM, VIRapid Tularemia 1 immunochromatographic test, an in-house ELISA IgG y an in-houseELISA IgM). El diagnóstico de tularemia fue establecido en base a la clínica y la confirmación mediante microaglutinación (MAT).

Resultados: La sensibilidad y especificidad de las pruebas fueron VIRCLIA Tularemia ( $91,8 \%$ y 96,7\%), VIRAPID tularemia ( $90,7 \%$ y $98,7 \%$ ), ELISA IgG $(90,1 \%$ y $97,4 \%)$, ELISA IgM $(90,1 \%$ y $97,4 \%)$ and MAT $(91,2 \%$ y $100 \%$ ). El $13,4 \%$ de los pacientes con serología positiva frente a Brucella fueron positivos en MAT, el 14,4\% en VIRAPID tularemia, el 15,5 en ELISA IgG, 12,4\% en ELISA IgM y 15,5\% en VIRCLIA Tularemia.

Utilidad de las pruebas serológicas VIRCLIA-TULAREMIA, microaglutinación, VIRAPIDTULAREMIA, EUSA IgG y ELISA IgM para el diagnóstico de la tularemia humana

\begin{tabular}{lcccc}
\hline & Sensibilidad & Especificidad & $\begin{array}{c}\text { Valor } \\
\text { predictivo }\end{array}$ & $\begin{array}{c}\text { Serología } \\
\text { positiva frente } \\
\text { a Brucella }\end{array}$ \\
\hline VIRCLA- & $91,8 \%$ & $96,7 \%$ & 93,0 & 15 \\
TULAREMIA & $(88,8-94,7)$ & $(92,6-99,5)$ & $(90,7-95,3)$ & $(84,5 \%)$ \\
Microaglutinación & $91,2 \% c ̧$ & $100 \%$ & 92,0 & 13 \\
VIRAPID- & $(88,2-94,3)$ & $(99,7-100)$ & $(91,6-95,9)$ & $(86,6 \%)$ \\
TULAREMIA & $90,7 \%$ & $98,7 \%$ & 93,0 & 14 \\
ELISA IgG & $(87,5-93,8)$ & $(96,5-100)$ & $(90,7-95,3)$ & $(85,6 \%)$ \\
ELISA IgM & $90,1 \%$ & $97,4 \%$ & 92,3 & 15 \\
& $(86,9-93,3)$ & $(94,5-100)$ & $(89,8-94,7)$ & $(84,5 \%)$ \\
& $90,1 \%$ & 97,4 & 92,3 & 12 \\
\end{tabular}

aPorcentaje (IC95\%), ${ }^{b}$ Número de sueros positivos (\%).

Conclusiones: La sensibilidad de todas las pruebas fue muy buena cuando se utilizaron sueros iniciales de pacientes con tularemia. Sin embargo, más del $13 \%$ de los pacientes con serología positiva frente a Brucella fueron también positivos en todas las pruebas serológicas frente a tularemia.

\section{HIDATIDOSIS: 15 AÑOS DE EXPERIENCIA EN EL HOSPITAL VALL D'HEBRON}

L. Escolà-Vergé, F. Salvador, A. Sánchez-Montalvá, E. Sulleiro, I. Bilbao, J.L. Lázaro, A. Rando, J. Salvador, X. Serres e I. Molina

\section{Hospital Vall d'Hebron, Barcelona.}

Introducción y objetivos: La equinococosis quística (EQ) o hidatidosis es una zoonosis parasitaria endémica en España, infranotificada, y con un espectro que está cambiando con el envejecimiento de la población, la inmigración y la inmunosupresión. El objetivo de este estudio es conocer el perfil epidemiológico y clínico de la EQ en un hospital de tercer nivel.

Material y métodos: Estudio retrospectivo, unicéntrico, realizado en el Hospital Universitario de la Vall d'Hebron (Barcelona), entre 2000 y 2015. Criterios de inclusión: pacientes $\geq 18$ años diagnosticados de EQ o seguidos por EQ en nuestro centro entre 2000 y 2015. Se recogieron datos demográficos, clínicos, radiológicos, serológicos y terapéuticos, así como la evolución clínica.

Resultados: Se seleccionaron 368 casos posibles de hidatidosis a partir del registro del hospital, del Servicio de Cirugía Hepática y del Servicio de Microbiología. 151 pacientes cumplían los criterios de inclusión. El 51,7\% eran mujeres. Mediana de edad al diagnóstico de 68 (rango 15-92) años. Veinte (13,2\%) eran inmigrantes y 30 (19,9\%), inmunodeprimidos. El motivo del diagnóstico fue sintomático en 54 $(35,8 \%)$ y un hallazgo radiológico en el resto. La localización hepática fue la más frecuente $(89,4 \%)$, seguida de la múltiple $(3,3 \%)$ y de hueso y/o partes blandas (3,3\%). Mediana del número de lesiones: 1 (1-10) y tamaño: 65 (13-300) mm. El 79,5\% de los quistes presentaban calcificaciones por imagen y la serología fue positiva en el 51,6\%. En 6 (4\%) pacientes se realizó un PET-TC por otro motivo pero en ningún caso hubo captación metabólica del quiste. Se realizó una actitud terapéutica expectante en 76 (50,3\%), cirugía en $67(44,4 \%)$ y tratamiento farmacológico en 8 (5,3\%). Un 20,5\% precisaron cambio de actitud por recidiva o progresión. El 58,1\% de las muestras de anatomía patológica evidenció signos de viabilidad. No encontramos una relación significativa entre calcificación en las pruebas de imagen y ausencia de viabilidad $(p=0,48$ ). La mediana de seguimiento fueron 57,7 (1-590) meses y hubo un $18,5 \%$ de defunciones, ninguna en relación con la hidatidosis. Cuando se compararon las características demográficas y clínicas según el estado de inmunosupresión se encontraron diferencias significativas en cuanto a la edad del diagnóstico, tipo de diagnóstico, tamaño del quiste, actitud terapéutica inicial, tiempo de seguimiento y defunciones.

Conclusiones: Nuestra población afecta de EQ es mayoritariamente autóctona. Las localizaciones de los quistes no han cambiado, la serología continúa siendo poco sensible para el diagnóstico y el tratamiento es poco exitoso con un porcentaje de recurrencias elevado. Desconocemos el comportamiento de la EQ en los pacientes inmunodeprimidos, un grupo de población que está creciendo y con un pronóstico cada vez mejor.

\section{ASPECTOS EPIDEMIOLÓGICOS Y CLÍNICOS DEL CHAGAS IMPORTADO EN UN HOSPITAL DE MADRID}

I. Carrillo Acosta', R. Pérez Tanoira', A. Cabello Úbeda',

L. Prieto Pérez'1, B. Álvarez Álvarez'1, M. Fernández Guerrero',

R. Fernández Roblas ${ }^{1}$, I. Gadea ${ }^{1}$, M. Orejas ${ }^{1}$, M. Tomás ${ }^{1}$, I. Cariñanos ${ }^{1}$, C.R. Fonseca Berzal², A. Gómez Barrio ${ }^{2}$

y M. Górgolas Hernández-Mora ${ }^{1}$

'Fundación Jiménez Díaz, Madrid. ${ }^{2}$ Universidad Complutense de Madrid, Madrid.

Introducción y objetivos: Debido a los movimientos migratorios desde zonas endémicas de Sudamérica, la enfermedad de Chagas, causada por Trypanosoma cruzi, ha convertido a España en uno de los países de área no endémica con mayor número de casos de la enfermedad. Nuestro objetivo es describir las características epidemiológicas y clínicas de los pacientes diagnosticados de Chagas en un hospital de Madrid.

Material y métodos: Estudio unicéntrico, descriptivo y con recogida retrospectiva de los datos epidemiológicos, clínicos y microbiológicos de los pacientes diagnosticados con la enfermedad de Chagas en la Fundación Jiménez Díaz (Madrid) entre 2009 y 2016.

Resultados: Se diagnosticaron 122 pacientes con infección por T. cruzi. La edad media de los pacientes fue de 39,82 $\pm 12,64$ años (rango $2-69$ años). De ellos 23 (18,9\%) eran hombres y 99 (81,1\%) eran mujeres. Un total de 115 pacientes $(94,3 \%)$ procedían de Bolivia y los otros 7 pacientes $(5,7 \%)$ de otros países latinoamericanos incluyendo: Ecuador $(2,5 \%)$, Paraguay $(2,5 \%)$ y Perú $(0,8 \%)$. Los ocho casos que se detectaron en niños (rango 2-15 años) eran de padres bolivianos residentes en España. Con respecto a la forma en la que estos pacientes fueron infectados, en 113 pacientes $(92,6 \%)$ la transmisión fue vectorial, en $5(4,1 \%)$ fue vertical y un caso $(0,8 \%)$ fue debida a una transfusión de sangre. Del total de pacientes el 20,4\% tenían manifestaciones cardiológicas y el $13 \%$ digestivas. El $36,3 \%$ y el $15,7 \%$ de los pacientes presentaron alteraciones en el ECG y ecocardio respectivamente. Los 25 pacientes con síntomas cardiológicos tenían: dolor torácico $(5,7 \%)$, palpitaciones $(5,7 \%)$, disnea $(4,1 \%)$, mareo $(2,5 \%)$, síncope $(1,6 \%)$ y ortopnea $(0,8 \%)$, ECG alterado $(45,4 \%)$ y ecocardio alterado (28,6\%). Al comparar los resultados obtenidos para ECG y ecocardiograma entre pacientes cardiológicamente asintomáticos y pacientes con síntomas cardiológicos no encontramos diferencias ( $p=0,325$ y 0,064 respectivamente). De 5 pacientes con estudio de RNM cardiaca, tan sólo uno tenía datos patológicos. Por otro lado, 19 pacientes $(15,5 \%)$ presentaron sintomatología digestiva: estreñimiento $(7,4 \%)$, reflujo $(2,4 \%)$, dolor abdominal $(3,3 \%)$ o disfagia $(2,4 \%)$. 


\section{Estudio comparativo de la utilidad de VIRCLIA- TULAREMIA frente a 4 pruebas serológicas para el diagnóstico de la tularemia humana.}

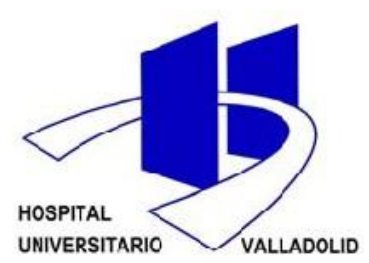

11Vग11

Orduña A., Durantez C., Cubero A., Gutiérrez MP., Castro MJ., March-Roselló G., López-Ramos I., Simarro M. Dpto Microbiología, Facultad de Medicina, Universidad de Valladolid. Hospital Clínico Universitario de Valladolid.

Objetivos: Tularemia es una zoonosis endémica en varias regiones del hemisferio norte que se presenta en forma de brotes epidémicos de forma periódica y como casos esporádicos en los períodos

interepidémicos. En España afecta

fundamentalmente a Castilla y León donde se han presentado dos brotes epidémicos (1997-98 y $2007-$ 08) con mas de 2000 casos confirmados. El objetivo de este estudio es conocer la utilidad de una prueba de quimioluminiscencia monotest comercial para el diagnóstico serológico de la tularemia humana.
Métodos: Se han utilizado 364 sueros obtenidos en la primera consulta de pacientes diagnosticados de tularemia (sueros iniciales), 152 sueros de donantes sanos, 100 sueros de pacientes con sospecha de tularemia no confirmada, 97 sueros de pacientes con brucelosis o serología positiva frente a Brucella, 30 sueros de pacientes con otras infecciones y 30 sueros de pacientes con enfermedades autoinmunes. Se han ensayado 5 pruebas serológicas (quimioluminiscencia monotest comercial (CHT) (VIRCLIA Tularemia IgG+lgM), inmunocromatografía (ICT) (VIRapid Tularemia), ELISA IgG y ELISA IgM frente a lipopolisacarido. El diagnóstico de tularemia fue establecido en base a la clínica y la confirmación mediante microaglutinación (MAT) según criterios CDC.

Tabla 1: Sensibilidad, especificidad, valor predictivo positivo (PPV), negativo (NPV), razón de probabilidad positiva (PLR) y negativa (NLR). (\% (IC 95\%))

\begin{tabular}{|l|l|l|l|l|l|l|}
\hline & \multicolumn{1}{|c|}{$\begin{array}{c}\text { Sensibilidad } \\
\text { Especificidad }\end{array}$} & PPV & NPV & Positive LR \\
\hline CHT & $91.8 \%(88.8-94.7)$ & $96.1 \%(92.6-99.5)$ & $98.2(96.7-99.8)$ & $82.9(77.1-88.8)$ & $23.3(10.6-50.9)$ & $0.09(0.06-0.12)$ \\
\hline MAT & $91.2 \%(88.2-94.3)$ & $100 \%(99.7-100)$ & $100(99.8-100)$ & $82.6(76.9-88.4)$ & $\infty$ & $0.09(0.06-0.12)$ \\
\hline ICT & $90.7 \%(87.5-93.8)$ & $98.7 \%(96.5-100)$ & $99.4(98.4-100)$ & $81.5(75.6-87.4)$ & $68.9(17.4-273.1)$ & $0.90(0.07-0.13)$ \\
\hline ELISA IgG & $90.1 \%(86.9-93.3)$ & $97.4 \%(94.5-100)$ & $98.8(97.5-100)$ & $80.4(74.4-86.4)$ & $34.2(13.0-90.1 .9)$ & $0.10(00.7-0.14)$ \\
\hline ELISA IgM & $90.1 \%(86.9-93.3)$ & $97.4(94.5-100)$ & $98.8(97.5-100)$ & $80.4(74.4-86.4)$ & $34.2(13.0-90.1 .9)$ & $0.10(00.7-0.14)$ \\
\hline
\end{tabular}

Tabla 2: Especificidad en 100 pacientes con sospecha de tularemia no confirmada, 97 pacientes de brucelosis o serología positiva frente a brúcela, $\mathbf{3 0}$ pacientes con otras infecciones y $\mathbf{3 0}$ pacientes con enf. autoimnunes

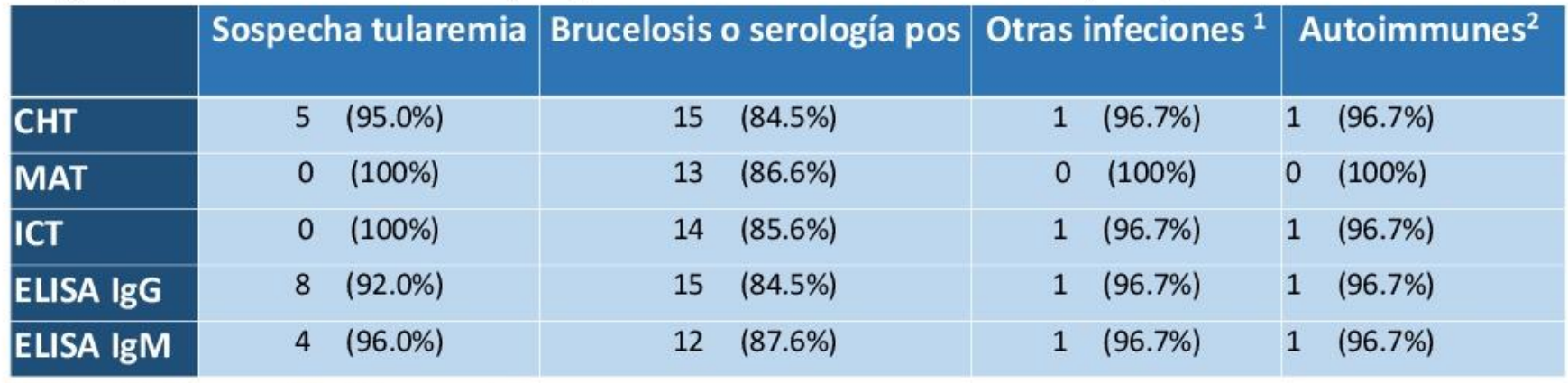

${ }^{1}$ Fiebre tifoidea. $\quad{ }^{2}$ Artritis reumatoide

Conclusiones: La prueba de quimioluminiscencia monotest presenta unas características de alta sensibilidad y especificidad en el diagnóstico serológico precoz de la tularemia humana similar al mostrado por las pruebas de microaglutinación, inmunochromatografia, ELISA IgG y ELISA IgM. Por su diseño presenta la característica de poder ser realizada individualmente disminuyendo el coste del ensayo y la hace especialmente útil cuando es preciso estudiar uno o dos sueros como ocurre en zonas de baja endemicidad o en períodos interepidémicos. 